José Carlos Callegari

\title{
UMA RELEITURA DA SUBORDINAÇÃO
}

Dissertação de Mestrado apresentada ao Departamento de Direito do Trabalho e da Seguridade Social da Faculdade de Direito da Universidade de São Paulo como requisito parcial à obtenção do título de Mestre.

Orientador: Professor Associado Jorge Luiz Souto Maior

FACULDADE DE DIREITO DA UNIVERSIDADE DE SÃO PAULO SÃO PAULO 
TEMA

UMA RELEITURA DA SUBORDINAÇÃO 
“Ser Radical É tomar as coisas Pela Raiz. Mas para o HOMEM, A RAIZ É O PRÓPRIO HOMEM"

Karl MarX - Crítica À Filosofia do Direito de Hegel

Dedico este trabalho a todas as LUtAdoras E TODOS OS LUTADORES QUE OUSARAM SER RADICAIS E COLOCAR O SER HUMANO EM PRIMEIRO LUGAR. 


\section{AGRADECIMENTOS}

Em primeiro lugar gostaria de agradecer aos meus pais, que plantaram em mim a semente do pensamento crítico e da indignação. Aos meus irmãos que, ainda que distantes, sempre proporcionaram fraternal convivência familiar.

Agradeço a todos os colegas que partilharam experiências, questionamentos e críticas ao longo do cumprimento dos créditos de disciplinas da pós-graduação. Em especial, agradeço aos Professores Eleutério Prado e Francisco de Oliveira por terem me proporcionado grandes momentos de reflexão acadêmica.

Agradeço ao Professor Jorge Luiz Souto Maior, meu orientador, companheiro de luta e de ideias, e que, além de um professor, tornou-se um amigo, pela liberdade acadêmica tão difícil de encontrar na Universidade

Agradeço aos Professores Marcus Orione Gonçalves Correia e Paulo Eduardo Vieira de Oliveira que, além da convivência durante a minha graduação que me ajudou a despertar para o direito social, deram valiosas contribuições na Banca de Qualificação.

Agradeço à Mila, meu amor, pela valorosa revisão, compreensão e apoio durante todo o processo de confecção deste trabalho.

Agradeço ao Gustavo, grande amigo com quem partilhei reflexões e com quem decidi seguir carreira na advocacia.

Por fim, agradeço a todos os meus amigos pelas conversas, viagens, encontros e desencontros que fazem florescer a beleza da vida. 


\section{RESUMO}

A subordinação jurídica é elemento preponderante para a caracterização da relação de emprego, base de incidência das normas do direito do trabalho. Diante disso é de fundamental importância entendermos seu significado e dimensão no contexto contemporâneo de profundas transformações no mundo do trabalho, que alteram inclusive a forma como o direito se insere na realidade. A subordinação do trabalho ao capital cria um grupo de detentores de mão-de-obra que necessitam da proteção do direito do trabalho. Essa análise é importante para entendermos o mundo do trabalho e a indispensável proteção jurídica que lhe é conferida pelo direito trabalhista. O presente estudo tem por objetivo lançar olhar estruturante sobre essas questões para incrementar a proteção trabalhista e regulamentar as relações de trabalho a partir dos valores da função social do trabalho e da melhoria das condições econômicas e sociais dos trabalhadores.

Palavras-chave: Direito do trabalho, subordinação, organização produtiva, relação de emprego. 


\begin{abstract}
The legal subordination is an indispensable element for the characterization of the employment relationship, base of the standards of labor law. Considering this is wich fundamental importance to understand its real meaning and dimension in the contemporary context of profound changes in the workplace, including altering the way the law is part of the reality. The subordination of labor to capital creates a group of holders of manpower that need the necessary protection of labor law. This analysis is important to understand the world of labour and the necessary legal protection conferred on it by the labor law. This study is looking to shed on these structural issues to increase labor protections and regulate the labor relations from the values of the function of labor and the improvement of economic and social conditions of workers.
\end{abstract}

Keywords: Labour law, legal subordination, produtive organization, employment relationship. 


\section{Sumário}

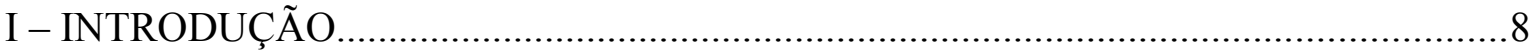

II - A RELAÇÃO CAPITAL X TRABALHO ………………………………………...15

II.1 - O papel do trabalho na sociabilidade humana: análise crítica.................................15

II.2 - O trabalho sob o capitalismo: estranhamento..................................................17

II.3 - Processo de trabalho e processo de troca...............................................................2

II.4 - A forma jurídica da relação capital X trabalho......................................................24

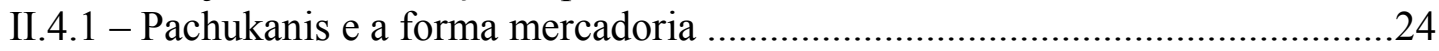

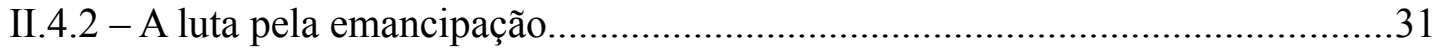

II.4.3 - A busca de freios jurídicos.........................................................................32

III - A NECESSÁRIA PROTEÇÃO JURÍDICA ……………………………………….........

III.1 - Direito civil e direito do trabalho: o mito do trabalho livre .....................................34

III.2 - A regulação das relações de trabalho sob a ótica da proteção social........................43

III.3 - A configuração da relação de emprego..................................................................45

III.3.1 - Organização do trabalho e da produção: a gerência científica........................46

III.4 - O elemento subordinação como fonte primária de direitos.....................................49

III.5 - A subordinação como elemento necessário à afirmação de direitos sociais nas

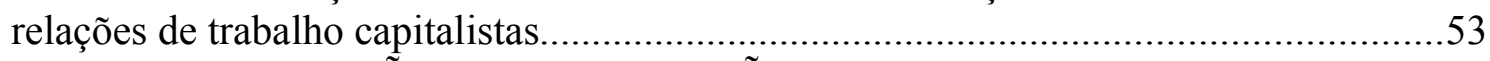

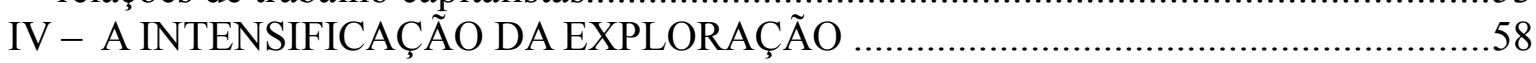

IV.1 - Terceirização, subcontratação e precarização do trabalho .....................................59

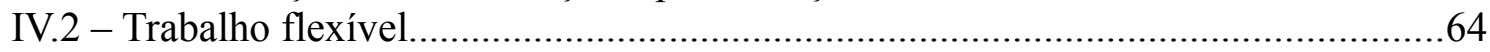

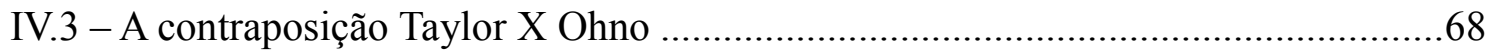

IV.4 - Novas formas de exploração do trabalho...........................................................73

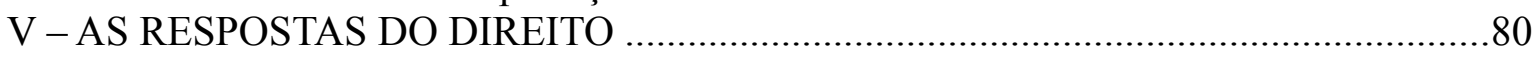

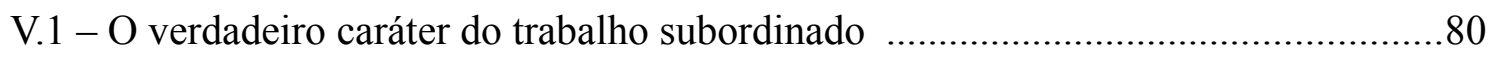

V.2 - Retratos de uma subordinação jurídica................................................................... 83

VI - COMO OS TRIBUNAIS ENXERGAM TUDO ISSO (JURISPRUDÊNCIA

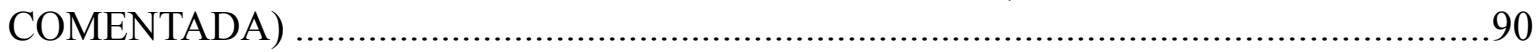

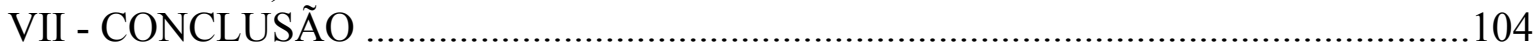

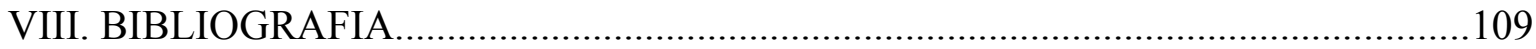

ANEXO 


\section{I - INTRODUÇÃO}

A presente dissertação de mestrado é fruto da continuidade de um trabalho de pesquisa realizado como monografia para obtenção do título de bacharel pela Faculdade de Direito da Universidade de São Paulo, no Departamento de Direito do Trabalho e da Seguridade Social, sob a orientação do Prof ${ }^{\circ}$ Jorge Luiz Souto Maior, que orientou também a dissertação que ora se apresenta.

Naquele estudo, realizado sob o título de "O conceito de subordinação em face das diferentes forma de organização do trabalho", realizamos uma investigação científica com o objetivo de compreendermos melhor a perenidade ou não do conceito jurídico de subordinação, do trabalhador que presta serviços através de uma relação de emprego, em face das transformações ocorridas na forma de organização do trabalho ao longo das últimas décadas.

Para tanto empreendemos esforços para compreender o fenômeno jurídico da subordinação a partir da colocação do problema sob os pontos de vista histórico, sociológico e econômico da relação entre capital e trabalho.

$\mathrm{Na}$ busca pela gênese da subordinação jurídica, deparamo-nos com diversas conceituações: desde a dita clássica, da relação de emprego, até a perspectiva da elaboração dogmática de novos modelos de representação da posição do trabalhador empregado em face de quem toma seus serviços o empregando. Elaborou-se um estudo prévio, que desse conta das novas modalidades de organização do trabalho e da produção no manto do fim do fordismo.

A chamada "transição pós-fordista" foi analisada com o fito de situar o problema jurídico dentro do fenômeno social que o informa, transforma e por ele é informado. Nessa perspectiva observamos a formulação de um novo paradigma de organização do trabalho, identificado pelo termo "toyotismo", como forma de busca pelo incremento das taxas de produção, e como resposta a uma crise geral - a mais aguda na produção mundial a partir dos choques do petróleo e da crise da década de 70. O modelo toyota de gerência da empresa também pode ser encarado como forma de readequação das atividades produtivas 
à crise de todo um modelo de produção e consumo da era fordista.

$\mathrm{Na}$ grande maioria das vezes tal remodelagem da forma de produzir mercadorias se deu em benefício da acumulação capitalista e em desfavor da classe trabalhadora, que participa com o trabalho da conflituosa relação com o capital. Esse embate entre forças sociais componentes das relações de produção teve impacto e resposta nas formas jurídicas estabelecidas para dar conta dessa nova realidade. Dentro da academia trabalhista, nas décadas de 80 e 90, viu-se uma profusão enorme de ideias de flexibilização de direitos trabalhistas, sob a insígnia de modernização de um ramo do direito que tinhas suas formulações galgadas em um modelo que não mais existia: o fordismo.

Algumas dessas teses atingiram o legislativo e o judiciário, e foram responsáveis, por exemplo, , pela legalização da terceirização a partir da atividade legislativa doTribunal Superior do Trabalho; bem como em âmbito legislativo, pela lei sobre o trabalho temporário e pela permissão da interposição de mão de obra de vigilância para bancos por parte do legislativo.

A Constituição Federal de 1988, marco da redemocratização e da cidadania, representou enormes avanços para diversas áreas do direito, inclusive o direito do trabalho, que fora inserido na lógica dos direitos sociais. A constitucionalização de tais direitos avançou o debate jurídico em torno da proteção do trabalhador e efetividade da justiça social.

Este marco, todavia, deu-se durante a supracitada proliferação de teses contrárias aos direitos dos trabalhadores e, ainda hoje, percebemos um grande exercício hermenêutico, por parte da doutrina trabalhista, no sentido de encampar a flexibilização do direito do trabalho como resposta social à organização do trabalho e como forma de equilíbrio das forças sociais com vistas a geração de emprego e renda. Mais do que afirmamos o tom falacioso de tais teses e evitando um maniqueismo jurídico nada científico e muito anti acadêmico, iremos aprofundar nesse nosso estudo a investigação sobre o direito do trabalho inserido na ordem capitalista de produção e como se dão - ou devem se dar - respostas que busquem efetivamente a melhoria das condições materiais do trabalho e do trabalhador.

Para tanto, faremos inicialmente, como forma de colocação do problema objeto de 
nosso estudo, uma análise do trabalho inserido na lógica do modo de produção capitalista. Nesse sentido, buscando escopo na literatura marxista e nos próprios escritos de Marx, exploraremos a necessidade do trabalho como fonte geradora de riqueza dentro do capitalismo. Assim, debruçaremo-nos sobre conceitos oriundos do mundo do trabalho para termos uma visão totalizante da atividade laborativa com o intuito de produção de mercadorias sob o capitalismo.

Em um momento seguinte, iremos nos debruçar especificamente sobre a exploração do trabalho como forma necessária e determinada de utilização da mão de obra no processo de produção capitalista. Isso, além de nos fornecer elementos para uma crítica do trabalho sob o capitalismo, nos servirá para a demonstração da necessária subordinação deste ao capital e como a forma jurídica da subordinação na relação de emprego - tal qual ela é entendida e formulada atualmente dentro da academia trabalhista - é apenas uma secção do mundo material, não compreendendo todos os fenômenos que abrangem a dinâmica do modo de produção vigente.

Após essa análise das determinações do trabalho sob o capitalismo, passaremos à análise dos fenômenos jurídicos propriamente ditos. Antes, porém, de adentrarmos ao campo do direito será necessário fazer uma recolocação do problema: a análise marxista da sociedade capitalista sugere, em última instância, que a superação do atual estado de coisas só se dará com a supressão ${ }^{1}$ do modo capitalista de produção e a implantação do comunismo. Essa supressão só pode ser atingida com a revolução socialista, porém o direito não possui esse caráter revolucionário, sendo que seu papel apenas representa alguns paliativos, sem efetivar mudanças estruturais na sociedade capazes de imprimirem uma mudança radical no modo de produção.

Assim, reforçando esse papel do direito, sem cair na crítica ácida e voraz de que não há saída viável para a solução das mazelas do capitalismo, é que iremos analisar como a forma jurídica é inserida na lógica mercantil e como as estruturas do direito podem ser aproveitadas em nome da justiça social e da melhoria das condições materiais de vida dos trabalhadores, colocando a questão da emancipação na agenda dos movimentos sociais.

1 Nesse ponto faz-se necessária uma observação: em seus escritos Marx usa a expressão Aufhebung, que seria melhor explicada como uma negação determinada do passado que avança rompendo com suas estruturas ao mesmo tempo que mantém o que pode ser aproveitado. Em algumas traduções de sua obra encontramos as seguintes palavras como sua definição: superação, supressão, ruptura, suprasunção (sendo essa a mais correta do ponto de vista metodológico) 
A partir de então, nos debruçaremos sobre algumas questões concernentes ao direito do trabalho. Primeiramente, iremos abordar a questão - ou mito - do trabalho livre. Partindo do entendimento de que não há trabalho verdadeiramente livre sob o capitalismo, bem como de que o trabalhador vende sua força de trabalho porque precisa sobreviver, , iremos pontuar a subordinação do trabalho e do trabalhador como resultado histórico e determinado do capitalismo.

Alguns autores que já abordavam essa questão quando da formação do direito do trabalho e de seu descolamento em relação ao direito civil serão objeto de estudo.. A ótica do direito social também não será deixada de lado, sempre com vistas a afirmar que o trabalho livre, na verdade, não existe. Falar em trabalho livre, no sentido em que estamos adotando, é bem diferente de falar em trabalho livre em contraposição ao escravismo. Nesse último ponto faz sentido tal diferenciação, porém o alargamento das possibilidades de uso da expressão dá margem a uma compreensão errada do problema, pois como já afirmamos no capitalismo o trabalhador não vende sua força de trabalho em um maravilhoso e utópico mercado perfeito em que as partes estão em pé de igualdade e fazem o que bem entendem quando querem, ele vende seu trabalho em troca da sua própria sobrevivência para um indivíduo que toma seus serviços e é detentor dos meios de produção. Portanto a relação é em si desigual e se dá em maior benefício de apenas uma das partes, que utiliza o trabalho alheio para acumulação e reprodução do capital.

No momento seguinte, iremos abordar a questão da configuração da relação de emprego para fins de incidência do direito do trabalho. Contudo, iremos abordar a relação de emprego não apenas como um fenômeno jurídico isolado, mas sim como uma forma particular e historicamente determinada de configuração da relação de trabalho.

Não se pode entender a moldura que o direito empresta a essa relação sem compreendermos também porque a produção de mercadorias se dá através de uma relação que, no âmbito jurídico, ficou chamada de empregatícia. Mais do que um apriori sem sentido do direito, a relação de emprego representa uma maneira específica de organização do trabalho. E deve ser compreendida dentro da totalidade do sistema capitalista, para que possamos melhor identificar os problemas e as deficiências que ela representa e podermos, com mais propriedade, pontuar o debate em que nos estamos inserindo a partir de uma visão crítica e transformadora da realidade. 
Isso feito, iniciaremos a abordagem da questão crucial de nossa investigação: a subordinação jurídica como elemento substantivo da relação de emprego e fonte primária de direitos. Partindo do entendimento de que o direto do trabalho, tal qual hoje configurado, representa um modelo de proteção jurídica a um tipo característico de trabalhador o assalariado-subordinado - faz-se necessário que, para uma compreensão mais acurada do próprio ordenamento jurídico, tenhamos com clareza como a subordinação, pode e deve ser caracterizada.

A ampliação de formas de extração do produto do trabalho alheio gera como consequência uma gama de trabalhadores que, ainda que explorados - por vezes até de forma mais aprofundada - fique de fora da proteção trabalhista. Não se pretende, contudo, fazer apologia ao aumento da competência material do direito do trabalho sem que isso signifique efetivamente um ganho social relevante. Ao estudarmos a subordinação, além de perpassarmos pelas discussões jurídicas sobre dependência do empregado ao empregador, buscamos a identificação e possível adequação de uma moldura jurídica a um fenômeno geral e mais amplo de subordinação real do trabalho ao capital.

Para tanto não poderíamos deixar de afirmar uma posição metodológica clara sobre o papel do trabalho na sociedade produtora de mercadorias. Assim, afirmamos a necessidade de compreensão do capitalismo a partir da centralidade do trabalho em nossa sociedade. Sem entrarmos em polêmicas um tanto quanto desnecessárias com cada uma das posições teóricas que afirmam ou infirmam a centralidade do trabalho, iremos adotar uma postura que se justificará na colocação do trabalho como categoria sociológica fundamental para a abordagem jurídica que pretendemos desenvolver.

A partir desse momento, com as bases metodológicas colocadas, poderemos entrar no momento de nossa exposição que irá à releitura a qual nosso tema alude, tanto da subordinação como da própria forma de exploração do trabalho. Colocando a questão acerca da forma como podemos identificar de maneira analítica, a partir dos pressupostos afirmados no momento precedente de nosso estudo, iremos situar nosso debate jurídico na realidade atual da organização do trabalho e da produção.

Para tanto, iremos nos concentrar nos conceitos que, a partir da sociologia do trabalho, podem nos ajudar a exprimir a forma intensificada de exploração do trabalho 
humano. No primeiro momento dessa abordagem iremos debater o conceito de trabalho flexível, o que ele representa, e como ele se manifesta na organização da produção. A flexibilidade do trabalho muitas vezes é relatada como um ganho para o próprio trabalhador, que não precisa mais ficar "preso" às estruturas rígidas do modelo de produção fordista e pode explorar suas potencialidades ao infinito.

Porém, buscaremos denunciar a falácia de tais argumentos ao demonstrar que a flexibilidade do trabalho na sociedade contemporânea apenas expressa uma necessidade de adaptação do capital para manutenção e incremento das taxas de exploração do trabalho.

Nesse sentido, iremos abordar de maneira detida a chamada gerência científica do trabalho a fim de entendermos como determinadas formas de organização da produção estão sempre voltadas para o incremento da própria produção e nunca para a melhoria das condições materiais dos trabalhadores. Para tanto, iremos comparar os métodos de gerência científica adotados pelos modelos fordista-taylorista e toyotista.

Isso posto, empreenderemos esforços no sentido de caracterizar as formas atuais de organização do trabalho e da produção como novas formas de intensificação da exploração do trabalho. Isso se justifica dentro da lógica da sociedade produtora de mercadorias, na medida em que seria irracional do ponto de vista do capitalismo que o trabalho humano deixasse de ser explorado ou que fosse mitigada a sua exploração em detrimento do aumento dos níveis de produtividade e lucro.

Traçando em linhas claras o nosso posicionamento interpretativo da sociedade capitalista poderemos, de forma coerente e intelectualmente honesta, enfrentar a questão de como o direito dá resposta a todos esses fenômenos e qual modelo jurídico de proteção do trabalhador que entendemos ser o adequado.

Buscaremos analisar teorias sobre o direito do trabalho que buscam avançar a proteção trabalhista, desejosos da adaptação do direito aos novos tempos, mas com viés totalmente diferente das teorias "modernizantes" da flexibilização. Iremos analisar teorias que busquem encontrar novas formas de atuação do direito do trabalho sempre na perspectiva da melhoria das condições econômicas e sociais do trabalhador para traçar um panorama da questão afeta ao nosso tema nos dias atuais. 
Por fim, faremos uma análise de jurisprudência sobre o tema abordado. Pretendemos, ao comentar decisões judiciais, mostrar que é possível atuar de maneira crítica, seja no caso dos magistrados - proferindo decisões mais favoráveis ao trabalhador - seja no caso dos advogados - formulando teses e fazendo requerimentos que, mesmo fadados ao fracasso do indeferimento, fazem diferença .

Buscar entender a subordinação jurídica do empregado a partir da lógica da exploração do trabalho representa lançar um dado de realidade para dentro do direito. Buscar entender o fenômeno jurídico a partir de seu substrato fático-social é também abrir caminho para novas teorias que possam melhorar o direito tendo sempre em vista avanços sociais que o ordenamento não pode barrar, mas deve privilegiar. 


\section{II - A RELAÇÃO CAPITAL X TRABALHO}

\section{II.1 - O papel do trabalho na sociabilidade humana: análise crítica}

O caráter subordinado do trabalho no capitalismo decorre da própria forma de organização capitalista da produção. É impossível pensarmos o capitalismo sem compreendermos que o trabalho humano organizado para a produção de mercadorias e reprodução do capital esteja essencialmente a esse subordinado. No sistema capitalista o trabalho serve à produção de mercadorias.

O trabalho humano, porém, não é apenas isso. Trabalho é também a interação do homem coma natureza. É importante frisarmos que a crítica ao trabalho que realizamos nesse estudo é a crítica do trabalho sob o capitalismo. Não pretendemos fazer uma apologia da sociedade do não-trabalho ou reivindicarmos a abolição dessa atividade humana fundamental.

Sobre a afirmação do trabalho como atividade humana fundante, Friedrich Engels, em texto publicado pela primeira vez em 1896 sob o elucidativo título "Sobre o papel do trabalho na transformação do macaco em homem" escreve:

\footnotetext{
"O trabalho é a fonte de toda a riqueza (...). O trabalho, porém, é muitíssimo mais do que isso. É a condição básica e fundamental de toda a vida humana. É em tal grau que, até certo ponto, podemos afirmar que o trabalho criou o próprio homem"2.
}

Diante de tal reflexão, Engels aborda as condições que fizeram com que o trabalho tomasse papel central nas relações humanas, e a maneira como o capitalismo alterou e tornou complexo o trabalho humano.

Karl Marx, ao analisar o processo de trabalho na produção de mercadorias, afirma:

\footnotetext{
"o processo de trabalho, como o apresentamos em seus elementos simples e abstratos, é atividade orientada a um fim para produzir valores de uso, apropriação do natural para satisfazer a necessidades humanas, condição universal do metabolismo entre o homem e a Natureza, condição natural eterna da vida humana e, portanto, independente de qualquer forma dessa vida, sendo antes igualmente comum a todas as suas formas sociais". 3
}

2 ENGELS, Friedrich. Sobre o papel do trabalho na transformação do macaco em homem in: ANTUNES, Ricardo (org.). Dialética do Trabalho. São Paulo: Expressão Popular, 2004. p. 14.

3 MARX, Karl. O capital: crítica da economia política. Tradução de Régis Barbosa e Flávio R. Kothe. $3^{\mathrm{a}}$ 
Essa afirmação merece uma análise um pouco mais detida de nossa parte. A orientação do trabalho para a produção de valores de uso significa - sem entramos na intrincada distinção feita por Marx entre valor de uso e valor de troca - que o trabalho humano possui como natureza intrínseca a interação com a natureza a fim de criar utilidades, ou seja, o trabalho possui um papel na sociedade que não pode ser desprezado . A afirmação de que tal trabalho é uma "condição eterna da vida humana" e "comum a todas as suas formas sociais" abre caminho para uma profunda reflexão sobre a utilização do trabalho pelo capitalismo e sua forma determinada sob esse modo de produção. É nesse ponto que concerne a crítica ao trabalho da qual comungamos.

Mais adiante podemos ter um belo exemplo da forma como o trabalho é encarado por Marx:
"o trabalhador trabalha sob o controle do capitalista a quem pertence seu trabalho.
O capitalista cuida de que o trabalho se realize em ordem e os meios de produção sejam empregados conforme seus fins, portanto, que não seja desperdiçada matéria-prima e que o instrumento de trabalho seja preservado, isto é, só seja destruído na medida em que seu uso no trabalho o exija". ${ }^{4}$

Essa última citação se insere perfeitamente no contexto de nosso estudo, na medida em que Marx traça, em 1867 - data da primeira edição de "O Capital" - o que posteriormente a doutrina justrabalhista definirá como um dos elementos determinantes da subordinação jurídica: o poder de direção e controle do empregador.

Pois bem. Colocadas essas primeiras perspectivas, podemos passar à crítica propriamente dita do trabalho sob o capitalismo . Ressalta-se que, com tal introdução, pretende-se tratar do papel do trabalho para a sociabilidade humana, afastando a crítica indiscriminada e carente de historicidade do trabalho na sociedade produtora de mercadorias, bem como buscamos afirmar a importância do trabalho para o ser humano como forma de lineamento de toda a nossa exposição.

ed. São Paulo: Nova Cultural, 1988. p. 146.

4 Ibidem. p. 147. 


\section{II.2 - O trabalho sob o capitalismo: estranhamento}

A crítica do trabalho sob o capitalismo será baseada no conceito de estranhamento que Marx desenvolveu e usou, precipuamente, em seus "Manuscritos econômicofilosóficos". Essa obra não teve a pretensão, por parte de seu autor, de ser um estudo acabado e serviu mais como forma de norteamento dos estudos do próprio Marx do que um título pronto para publicação, tanto é que apenas em 1932 é que tais escritos vieram à tona e foram publicados.

Inicialmente, cumpre traçarmos algumas linhas acerca de tal obra ${ }^{5}$. Os "Manuscritos", apesar de terem sido escritos por Marx em 1844, somente foram publicados em 1932 na antiga União Soviética, como fruto do trabalho do Instituto Marx-Engels, responsável pela organização e publicação das obras de Marx e Engels. Ressalta-se que o lapso temporal de 90 anos se deu porque essa obra não teve a pretensão de ser um estudo acabado, mas sim de ser uma forma de norteamento dos estudos de Marx.

Os manuscritos de 1844 representaram uma transição na forma de estudar o marxismo no século XX. Se antes os estudiosos focavam somente na teoria econômica formulada por Marx, , a partir da publicação dessa obra, passaram a focar também no marxismo sob o aspecto filosófico. Assim, além da economia, a teoria proposta por Marx passou a ser compreendida também como filosofia. Isso representa um grande avanço, na medida em que a emancipação humana toma contornos filosóficos, deixando de ser apenas uma questão de produção e alocação de recursos.

O texto dos manuscritos teve forte repercussão, em grande medida, pelo contexto político dos anos 30: muitos teóricos opositores do regime soviético usaram-no para criticar o processo de stalinização da URSS, a partir do argumento de Marx de que a emancipação humana só se dá com a superação do trabalho alienado, não realizada pela Estado socialista.

Sob forte influência de Feuerbach ${ }^{6}$ Marx dá um passo adiante na teoria hegeliana.

5 As informações aqui enunciadas sobre a obra foram tiradas do evento realizado pelo LEMARXUSP(Laboratório de Estudos Marxistas da Universidade de São Paulo) sobre os "Manuscritos Econômicos-filosóficos" que teve como palestrante o Prfo Ruy Braga, do Departamento de Sociologia da FFLCH-USP.

6 Filósofo materialista ateu alemão, integrou o grupo dos chamados "Jovens Hegelianos" e exerceu forte influência sobre o começo dos estudos do próprio Marx. 
Hegel diria que o homem é o deus alienado, Feuerbach diria o contrário, que deus é o homem alienado. A alienação religiosa é um fator de desefetivação do homem e essa alienação precisa ser superada. Ao substituir deus pela propriedade privada, Marx junta o ateísmo ao comunismo como forma de desalienação positiva do homem.

A alienação humana tem como fundamento a alienação do homem em relação ao trabalho. Marx usa a expressão estranhamento para descrever a situação do ser humano perante um trabalho que não lhe pertence e que não é usado para seu fim. O trabalho estranhado tem como fundamento primeiro a propriedade privada. É por causa da propriedade privada que o trabalho humano produz riqueza para outros e não para si mesmo. Assim o trabalhador não se reconhece em seu próprio trabalho, atividade humana fundamental. A alienação do trabalho produz efeitos nefastos para o indivíduo que trabalha, pois ao mesmo tempo que o trabalho molda a relação do ser humano com a natureza, se essa relação estiver desumanizada, o ser humano perde o próprio caráter de sua espécie.

Essa alienação, ou estranhamento, é definida por Marx da seguinte maneira:
"O estranhamento do trabalhador em seu objeto se expressa, pelas leis nacional- econômicas, em que quanto mais o trabalhador produz, menos tem para consumir; que quanto mais valores cria, mais sem-valor e indigno ele se torna; quanto mais bem formado o seu produto, tanto mais deformado ele fica; quanto mais civilizado seu objeto, mais bárbaro o trabalhador; que quanto mais poderoso o trabalho, mais impotente o trabalhador se torna; quanto mais rico de espírito o trabalho, mais pobre de espírito e servo da natureza se torna o trabalhador" ${ }^{7}$

Quando Marx cita "leis nacional-econômicas", ele se refere a leis da economia política. É importante que se faça tal ressalva para que não haja confusões: Leis nacionaleconômicas não são as leis do direito que regem a economia - o que poderíamos chamar hodiernamente de direito econômico e financeiro -mas sim as leis gerais e não jurídicas da economia politica, como, por exemplo, oferta e demanda. Assim, a impotência do trabalhador diante do poder do trabalho, ou sua pobreza em face da riqueza de sua produção, são determinados pelas regras da economia capitalista. É a própria existência do

7 MARX, Karl. Manuscritos Econômico-filosóficos. Tradução de Jesus Ranieri. $3^{\text {a }}$ reimpressão. São Paulo: Boitempo, 2009. 
modelo capitalista de produção baseado na propriedade privada que faz o estranhamento do trabalhador frente a seu trabalho possível e real.

Ricardo Antunes, escrevendo sobre a alienação ou estranhamento do trabalhador em Marx, afirma que:

\begin{abstract}
"Esse processo de alienação do trabalho (que Marx também denomina como estranhamento) não se efetiva apenas no resultado - a perda do objeto -, mas abrange também o próprio ato de produção, que é o efeito da atividade produtiva já alienada. Se o produto é o resultado da atividade produtiva, resulta que esta se encontra também estranha ao trabalhador (...) O que significa dizer que, sob o capitalismo, o trabalhador não se satisfaz no trabalho, mas se degrada; não se reconhece, mas se nega". ${ }^{8}$
\end{abstract}

O estranhamento do trabalhador pode ser também caracterizado como alienação do próprio trabalho - "trabalho estranhado". Assim, é atribuído ao objeto a mesma caracterísstica do sujeito, ou ainda mais, o próprio processo de relação entre sujeito e objeto ganha a característica de um e dos dois elementos que o compõem. Assim, afirmamos juntamente com Antunes que a alienação do trabalho e o estranhamento do trabalhador são resultados de uma atividade produtiva já alienada. Nesse sentido, voltando ao texto dos Manuscritos, Marx afirma: "Se portanto perguntamos: qual a relação essencial do trabalho, então perguntamos pela relação do trabalhador com a produção". ."

Tem-se, então, uma lógica engendrada de produção de mercadorias que levam necessariamente à precarização do trabalho, à alienação do trabalhador, e ao estranhamento do mundo do trabalho em relação a seus meios e a seus fins. Assim, não nos resta outra alternativa que não pensar numa forma de mudança desse estado de coisas, sob pena de coadunar estarmos coadunando com tal status quo. Não há problema, contudo, em tomarmos uma posição ou outra, porém não podemos cair na tentação da imparcialidade, não somente porque ela é em si falaciosa, mas também porque estaríamos - ainda que não afirmássemos, ou ainda pior, que não soubéssemos - inevitavelmente assumindo uma posição e sendo intelectualmente desonestos.

8 ANTUNES, Ricardo. O caracol e sua concha: ensaios sobre a nova morfologia do trabalho. São Paulo: Boitempo, 2005. p. 70.

9 Op. cit. p. 82. 
Nesse sentido, buscamos fazer uma interpretação da realidade o mais sólida e coerente possível do ponto de vista político, social e econômico, para que possamos sempre que necessário nos referirmos a ela ou a autores aqui citados para defendermos determinado ponto de vista questionado. Assumimos um lado em todos os momentos em que somos questionados e, a partir desse momento, ou estamos errados e mudamos de opinião, ou temos a absoluta certeza de estarmos certos e não retrocederemos em nada do que dissemos.

Porém, para tanto, devemos buscar modelos e interpretações teóricas históricas, a fim de pensarmos projeções plausíveis e coerentes para o futuro. Nesse sentido, continuemos a entender a relação do trabalho no capitalismo a partir do seu fazer-se - o processo de produção.

\section{II.3 - Processo de trabalho e processo de troca}

Marx afirma n'O Capital que "a utilização da força de trabalho é o próprio trabalho. O comprador da força de trabalho a consome ao fazer trabalhar o vendedor dela". ${ }^{10}$ Assim o trabalho é a utilização dele, ou seja, o trabalho é o seu processo e o processo é o próprio trabalho. Não há como separar o trabalho humano da forma como ele é realizado. Dessa maneira, a forma como se organiza a produção de mercadorias define a própria forma do trabalho sob determinado modo de produção. Assim, Marx continua: "Não é o que se faz, mas como, com que meios de trabalho se faz, é o que distingue as épocas econômicas", concluindo "produtos são, por isso, não só resultados, mas ao mesmo tempo condições do processo de trabalho". ${ }^{11}$

Vivemos em uma sociedade em que a forma de organização do trabalho e da produção adquiriu novas e dramáticas nuances para a força de trabalho e para o ser humano que realiza o trabalho e se forja por ele. Dessa maneira quanto mais impositivo for o processo de trabalho do ponto de vista da exploração, mais o ser humano que trabalha será explorado e se não se identificará na sua atividade. Assim, passemos a analisar a exploração do trabalho em si.

O processo de troca está imbricado ao próprio processo de trabalho Mas por que estudamos o processo de troca capitalista inserido em um estudo sobre direito do trabalho?

10 Op. cit. p. 142.

11 Idem. p. 144. 
Ora, porque dentro da nossa linha de pesquisa, é preciso buscar e entender as determinações, mesmo as mais simples, que formam a concretude de nosso objeto de estudo. Nesse sentido, a troca de mercadorias muito se relaciona com o tema estudado. Marx começa o capítulo d'O Capital, sobre o processo de troca, com a seguinte frase: “As mercadorias não podem por si mesmas ir ao mercado e se trocar". ${ }^{12}$

Parece simples e banal tal afirmação, todavia, ela faz sentido dentro da lógica do rompimento dos conceitos tidos como naturalmente postos seja lá por quem em nossa organização social. $\mathrm{O}$ fato das mercadorias não poderem ir sozinhas ao mercado "se trocarem" significa que a ação humana não é somente necessária à troca de mercadorias, é fundamental. Dessa forma, o capitalismo se baseia, fundamentalmente, na relação entre proprietários de mercadorias, que as levam ao mercado para serem trocadas.

Essa relação entre possuidores de mercadorias acaba por determinar outras diversas relações sociais sob o capitalismo. Na verdade, Marx afirma que as relações econômicas determinam as relações sociais entre os indivíduos economicamente determinados: "Veremos no curso do desenvolvimento, em geral, que os personagens econômicos encarnados pelas pessoas nada mais são que as personificações das relações econômicas, como portadores das quais elas se defrontam". ${ }^{13}$

O processo de troca de mercadorias tem como fundamento primeiro o valor pelo qual determinada mercadoria será trocada. Marx faz uma longa exposição sobre o complexo processo de determinação do valor, baseado no valor de uso das mercadoriasobjeto da troca. Ressalta-se, todavia, que não iremos reproduzi-la neste estudo, devido ao seu caráter eminentemente econômico. Podemos, entretanto, afirmar que no final do processo de determinação do valor tem-se que as mercadorias devem ser trocadas por um equivalente que irá determinar o quantum de valor cada uma. Esse equivalente é fundamental para que a troca se efetive, pois ainda que uma mercadoria possa ser trocada por outra de acordo com o valor estabelecido pelos seus possuidores, a complexificação desse processo - que ocorrerá na medida em que mais e mais mercadorias forem trocadas tornaria inviável a determinação do valor caso a caso.

12 Idem. p. 79.

13 Idem. p. 80. 
Assim, temos a necessidade de um equivalente geral de troca, concretizado na moeda. Marx explica:

\begin{abstract}
"A ampliação e aprofundamento histórico da troca desenvolve a antítese entre valor de uso e valor latente na natureza da mercadoria. A necessidade de dar a essa antítese representação externa para a circulação leva a uma forma independente do valor da mercadoria e não se detém nem descansa até tê-la alcançado definitivamente por meio da duplicação da mercadoria em mercadoria e dinheiro. Na mesma medida, portanto, em que se dá a transformação do produto do trabalho em mercadoria, completa-se a transformação da mercadoria em dinheiro"14
\end{abstract}

Dessa maneira, temos a consubstanciação do processo de troca através de um equivalente geral: o dinheiro. Dinheiro este que é usado para comprar e vender tudo, inclusive o próprio trabalho humano, que é comprado e vendido tendo o dinheiro como mediador. Opera-se, assim, uma inversão lógica que - paradoxalmente - parece muito natural: o trabalho, que serve basicamente para a produção de mercadorias que serão trocadas por dinheiro, é pago com o dinheiro resultante da troca de seu produto. Assim, está aberto o campo para a exploração do trabalho sob o capitalismo. Marx termina o capitulo d'O Capital referente ao processo de trabalho:

\footnotetext{
"A conduta meramente atomística dos homens em seu processo de produção social e, portanto, a figura reificada de suas próprias condições de produção, que é independente de seu controle e de sua ação individual, se manifestam inicialmente no fato de que seus produtos de trabalho assumem em geral a forma mercadoria. O enigma do fetiche do dinheiro é, portanto, apenas o enigma do fetiche da mercadoria tornado visível e ofuscante"
}

Para bem compreendermos o que Marx quis dizer com a citação acima transcrita, temos que regressar um pouco n'O Capital. Imediatamente antes do capitulo sobre o processo de troca, Marx expõe o enigma do fetiche da mercadoria no sub-item 4 do capítulo "A mercadoria" cujo título é "O caráter fetichista da mercadoria e seu segredo". Nesse sub-capítulo, Marx explora como a mercadoria toma as características que lhe são atribuídas no capitalismo, e como essas características acabam por influenciar e determinar relações sociais. Assim, "tão logo os homens trabalham uns para os outros de alguma maneira, seu trabalho adquire também uma forma social". ${ }^{15}$ 
Nesse sentido enquanto o produto do trabalho humano é a mercadoria, e o próprio trabalho adquire forma social e é também vendido como se mercadoria fosse, o enigma da forma mercadológica transpassa o simples produto ou o simples comprar e vender. Marx explica que a mercadoria representa muito mais do que apenas um produto passível de ser comprado e vendido, ainda que muitas vezes - para não dizer todas - as características de representação da mercadoria fiquem escondidas por debaixo da aparência. A essencialidade por detrás das aparências não é vislumbrado no cotidiano. O essencial é negado aos homens. Parece tudo muito natural, porém não passa de uma determinação histórica e social:

"O misterioso da forma mercadoria consiste, portanto, simplesmente no fato de que ela reflete aos homens as características sociais do seu próprio trabalho como características objetivas dos próprios produtos de trabalho, como propriedades naturais sociais dessas coisas e, por isso, também reflete a relação social dos produtores com o trabalho total como uma relação social existente fora deles. Por meio desse quiprocó os produtos do trabalho se tornam mercadorias, coisas físicas metafísicas ou sociais. Assim, a impressão luminosa de uma coisa sobre o nervo ótico não se apresenta como uma excitação subjetiva do próprio nervo, mas como forma objetiva de uma coisa fora do olho. Mas, no ato de ver, a luz se projeta realmente a partir de uma coisa, o objeto externo, para outra, o olho. É uma relação física entre coisas físicas. Porém, a forma mercadoria e a relação de valor dos produtos de trabalho, na qual ele se representa, não têm que ver absolutamente nada com sua natureza física e com as relações materiais que daí se originam (...) Esse caráter fetichista do mundo das mercadorias provém, como a análise precedente já demonstrou, do caráter social peculiar do trabalho que produz mercadorias". ${ }^{16}$

Percebe-se que o caráter fetichista da mercadoria é extremamente pertinente ao objeto do presente estudo. Poderíamos ir além, ao dizer que o fetiche é pertinente a quaisquer relações sociais do mundo capitalista, na medida em que o fetiche determina as relações de troca que, por sua vez, determina as relações de produção, e que, por fim determina as relações sociais como um todo. A mercantilização do mundo fora denunciada por Marx muito tempo antes da escrita d'O Capital. "A burguesia rasgou o véu do sentimentalismo que envolvia as relações de família e reduziu-as a meras relações monetárias" já diziam Marx e Engels no famoso "Manifesto do Partido Comunista" de

16 Idem. p. 71. 
1848. Porém, apenas em seus escritos posteriores o filósofo alemão desenvolveu melhor tais ideias, aprofundando e embasando essa perspectiva.

No mundo do trabalho, especificamente, o caráter fetichista da mercadoria tem sérias e profundas implicações, como, por exemplo, o trabalho humano que, sob o capitalismo, produz e se transforma em mercadoria. Esse trabalho, mercantilizado e reificado, faz com que o trabalhador não mais se identifique nele e se veja como mera peça de uma engrenagem ainda maior de exploração.

Essa engrenagem de exploração repercute - como não poderia deixar de repercutir - no direito e, ainda que aparentemente de maneira dissociada na essência, determina a forma como as estruturas jurídicas se apresentam. Portanto é plenamente justificável e necessário enfrentarmos a questão da forma jurídica inserida no contexto da exploração do trabalho, conforme faremos a seguir.

\section{II.4 - A forma jurídica da relação capital $X$ trabalho}

Uma vez exposta essa visão do mundo do trabalho sob o capitalismo, devemos analisá-la sob a ótica do direito. Ainda que a perspectiva lançada sobre a relação entre capital e trabalho soe catastrófica - e, de fato, o seja - devemos ser otimistas. Acreditamos que outro mundo é possível, mas não temos certeza de que ele poderá ser alcançado através do direito. Apesar disso, detemos a técnica jurídica e devemos nos utilizar do conhecimento que adquirimos a fim de contribuir com a construção de um novo modelo de sociedade.

Nesse momento, iremos expor a inserção da relação entre capital e trabalho no mundo do direito, bem como enxergamos esta configuração, sempre pautados por uma técnica jurídica comprometida com a transformação da realidade e com a superação da acachapante espoliação do trabalho e do trabalhador por parte do capital.

\section{II.4.1 - Pachukanis e a forma mercadoria}

Eugeny Bronislanovich Pachukanis é o maior teórico marxista do direito, nem tanto pela profusão ou quantidade de seus escritos, mas sim pela robustez teórica e metodológica de sua obra. Seu livro "A Teoria Geral do Direito e o Marxismo", que teve sua primeira edição publicada em 1924, representa o estudo mais abrangente sobre a aplicação do 
método marxista a toda a Teoria Geral do Direito. O jurista soviético, que militara ativamente na Revolução de 1917 e chegou ao cargo de Vice-Comissário do povo para a Justiça, proferiu talvez a mais contundente crítica do papel do direito no capitalismo, crítica essa tão voraz que desagradou inclusive o establishment soviético, que o executou em 1937 sob o totalitarismo de Joseph Stálin, tendo sido formalmente reabilitado apenas em 1956, com o fim do regime stalinista.

Márcio Bilharinho Naves, estudioso do marxismo e do direito no Brasil, afirma que "relacionar a forma mercadoria com a forma jurídica resume, para Pachukanis, o essencial de seu esforço teórico". ${ }^{17}$ Assim, tudo o que aqui dissemos sobre a mercadoria, sobre seu fetiche, e sobre sua forma característica, para Pachukanis se relaciona intrinsecamente com a forma jurídica. É compreensível dado que a mercadoria representa o que há de mais essencial no modo de produção capitalista e sua reprodução passa necessariamente também pela forma mercadoria.

Metodologicamente, do ponto de vista marxista, não há dúvida que a análise pachukaniana para o direito é a mais coerente e acertada. Pachukanis, com maestria, conseguiu fazer a transposição do método da economia política - exposto por Marx - para o direito. A busca pelo elemento mais simples a partir do concreto para depois fazer a volta ao concreto a partir do simples, com todas as determinações que isso acarreta, chegando a uma concretude que não é apenas apriorística, implica necessariamente passarmos pela forma mercadoria como elemento de determinação das relações sociais e, por isso, também jurídicas. O direito inserido na lógica de produção capitalista, produto histórico de sua época, é um resultado mercantilizado das determinações capitalistas.

Pachukanis expôs em sua já citada obra uma das mais brilhantes explanações da aplicação para o direito do método que Marx utilizara para a economia política. O capítulo dedicado ao método da obra referida intitula-se "Os métodos de construção do concreto nas ciências abstratas".

Pachukanis parte do texto de Marx para fazer uma análise materialista do direito. Mais especificamente, do capítulo "O método da Economia Política", inserido na obra "Contribuição à Crítica da Economia Política". O texto do filósofo alemão se inicia com

17 NAVES, Márcio Bilharinho. Marxismo e direito: um estudo sobre Pachukanis. São Paulo: Boitempo, 2008. p. 53. 
uma afirmação sobre como os economistas clássicos estudavam a economia de um país, começando "por sua população, a divisão desta em classes, seu estabelecimento nas cidades, nos campos, na orla marítima; os diferentes ramos da produção, a exportação e a importação, a produção e o consumo anuais, os preços das mercadorias etc". ${ }^{18}$

Todavia, explica Marx, esse método não é o correto, apesar de parecê-lo. Começar pela população, algo concreto e real, parece acertado na medida em que é ela a base da economia, das relações de produção, porém “a população é uma abstração se deixo de lado as classes que a compõem. Essas classes são, por sua vez, uma palavra sem sentido se ignoro os elementos sobre os quais repousam, por exemplo: o trabalho assalariado, o capital etc. Esses supõem a troca, a divisão do trabalho, os preços etc". ${ }^{19}$

O que Marx afirma é que não se pode começar um determinado estudo - neste caso, de economia política, podendo ser aplicado a quaisquer outras áreas do conhecimento por algo aparentemente concreto, sem levarmos em conta a essencialidade da concretude desse elemento. Dessa maneira, não seria correto começar um estudo de Economia Política pela população simplesmente, na medida em que a população não representa, em absoluto, o que pode ser encontrado de mais concreto dentro do estudo da economia, por mais que assim possa parecer. A concretude do elemento população só pode ser auferida após outras análises., e não de plano.

Marx continua, afirmando que ao nos depararmos com um elemento aparentemente concreto e ponto de partida de um estudo, devemos ir destrinchando esse elemento até encontrarmos nele o que há realmente de concreto e simples. Quanto mais simples forem as determinações desse elemento, mais próximos do método correto de análise estaremos. Entendendo essas múltiplas determinações, estaremos concebendo realmente o que há de concreto formado por elas. "O concreto é concreto, porque é a síntese de muitas determinações, isto é, unidade do diverso". ${ }^{20}$ Essa famosa sentença de Marx exprime bem o núcleo do método materialista marxista. E Marx continua:

\footnotetext{
"Por isso, o concreto aparece no pensamento como o processo da síntese, não como ponto de partida, embora seja o verdadeiro ponto de partida e, portanto, o
}

18 MARX, Karl. Contribuição à crítica da economia política. Trad. e introd. de Florestan Fernandes. $2^{\mathrm{a}}$ ed. São Paulo: Expressão Popular, 2008. pp. 257-258.

19 Idem.

20 Ibidem. 
ponto de partida também da intuição e da representação. No primeiro método, a representação plena volatiliza-se na determinação abstrata; no segundo, as determinações abstratas conduzem à reprodução do concreto por meio do pensamento". 21

Assim, a elaboração do concreto não é apenas um exercício de observação do que é ou não é. Existem determinadas categorias de objetos que não há dúvida sobre sua concretude ou não. Uma cadeira é uma cadeira. Porém, a cadeira para fins de estudos sociais pode ser muito mais do que apenas um objeto para que as pessoas se sentem. Pode carregar em si muitas determinações que, ao final, podem representá-la de uma maneira completamente diferente do primeiro momento. Se formos transpor esse raciocínio para elementos muito mais complexos e socialmente determinados, a importância da busca pelo concreto como resultado final da análise mostra ainda mais maximizada.

Se o capitalismo baseia suas relações entre pessoas e coisas - e entre pessoas coisificadas - a partir das relações de troca, não haveria porque o direito capitalista não ser resultado dessas relações, não sendo também coisificado a partir da forma mercantil. $\mathrm{O}$ grande avanço na teoria do direito proposta por Pachukanis consiste, fundamentalmente, na supervalorização da forma em detrimento do conteúdo. Aliás, esse é um debate ainda em aberto nas ciências jurídicas, por incipiente que é.

Pachukanis não admite um conteúdo emancipatório do direito, na medida em que a forma jurídica que irá envolver esse conteúdo é a forma mercantil, que aprisiona o direito, amarrando os que com ele trabalham. Ressaltamos, todavia, que não comungamos de todo com tal avaliação, tendo em vista que acreditamos em uma possível atuação pelo direito, que sirva para a afirmação de direitos subjetivos das minorias em poder e que possa, ao menos, contribuir para um debate radicalmente democrático de mudanças sociais . Devemos, porém, nos espelhar no que talvez seja a forma mais acabada de aplicação do método marxista ao direito. Acabada, porém não completa e perfeita, senão perderia todo o seu caráter dialético. Não pretendemos, contudo, fazer retoques à obra do jurista soviético, tampouco propôr outra teoria em seu lugar - tarefa demasiadamente prepotente. Preocupamo-nos com o direito do trabalho, e para tal análise é imprescindível a

21 Idem. pp. 258-259 
radicalidade pachukaniana.

Foi no campo da teoria do direito que Pachukanis chegou a suas conclusões mais contundentes e fez suas afirmações mais profícuas. Nesse sentido, podemos dizer que para tal autor a teoria do direito tem um papel: estudar a forma jurídica como forma histórica, buscando substrato para isso na realidade. Assim podemos citar uma passagem de sua obra na qual ele critica as teorias do direito que não procedam dessa forma:

"Uma tal teoria geral do direito, que não explica nada, que a priori dá as costas às realidades de fato, quer dizer, a vida social, e que se preocupa com as normas, sem se preocupar com as suas origens (o que é uma questão metajurídica!), ou de suas relações com quaisquer interesses materiais, não pode pretender o título de teoria, senão o de teoria do jogo de xadrez. Uma tal teoria nada tem a ver com a ciência. Esta 'teoria' não pretende analisar o direito, a forma jurídica enquanto forma histórica, pois não visa a estudar a realidade. É por isso, para empregar uma expressão vulgar, que não há muito que se possa tirar dela"22

Pachukanis possui a ironia fina típica dos teóricos marxistas. Mas além de irônico, ele é preciso. A teoria do direito que não consegue enxergar a realidade não serve para muita coisa, pelo menos cientificamente, já que no plano ideológico tais teorias tem dado grandes contribuições à manutenção do estado de coisas da maneira que convém aos empoderados.

Por outro lado, Pachukanis faz a crítica aos teóricos do direito que, inspirados pela teoria marxista, apenas juntam novos elementos a uma análise do direito preexistente, sem mudar substancialmente a forma de interpretação jurídica. Para ele "daí não resulta mais do que uma história das formas econômicas com uma tintura jurídica. mais ou menos forte, ou uma história das instituições mas em nenhuma hipótese uma teoria geral do direito". ${ }^{23} \mathrm{e}$ continua "contudo não há dúvida de que a teoria marxista não deve apenas examinar o conteúdo concreto dos ordenamentos jurídicos nas diferentes épocas históricas, mas fornecer também uma explicação materialista do ordenamento jurídico como forma histórica determinada". ${ }^{24}$

22 PASUKANIS, Eugeny Bronislanovich. A teoria geral do direito e o marxismo. Trad. apres. e notas por Paulo Bessa. Rio de Janeiro: Renovar, 1998. p. 16.

23 Idem. p. 17.

24 Idem. p. 18. 
É justamente isso que ele procura fazer ao buscar na determinação da forma mercadoria a determinação maior da forma jurídica. A forma histórica determinada do ordenamento jurídico sob o capitalismo é orientada por e para o modo de produção. Assim não há como falar, para Pachukanis, em ordenamento jurídico de uma sociedade capitalista sem falarmos em forma mercadoria, na medida em que Marx inicia seu estudo sobre o capitalismo pela mercadoria e pelo valor, que são as condicionantes mais simples a partir do concreto.

Dessa mesma maneira, o direito capitalista também tem intrínseca relação com a forma mercadoria e a forma do valor. Pachukanis vai além, afirmando que não há como pensar o direito fora do capitalismo, pois as formas jurídicas de sociedades primitivas eram igualmente primitivas, "só a sociedade burguesa capitalista criou todas as condições necessárias para que o momento jurídico seja plenamente determinado nas relações sociais". ${ }^{25}$

Por esse entendimento o estudo do direito romano como forma de ordenamento avançado e pré acabado do nosso direito moderno seria anacrônico e não passaria de paleontologia jurídica. Talvez a crítica não seja perfeita, porém é inegável que na Roma antiga não tínhamos as relações sociais determinando plenamente o momento jurídico. $\mathrm{O}$ direito era feito para poucos por mais poucos ainda. Assim, como foi somente na sociedade burguesa capitalista que o direito alcançou sua força e desenvolvimento pleno, nada mais correto que entendê-lo a partir do modo de produção para o qual ele serve, ou seja, a determinação e o fetiche da forma mercadoria também imprimem sua lógica ao direito tal qual o conhecemos.

É assim que Pachukanis, citando Marx, dá uma valiosa lição sobre sua forma de entender o direito:

\footnotetext{
"Enquanto a relação entre os produtos individuais e a sociedade continua a conservar a forma de troca entre equivalentes, esta relação continuará a manter igualmente a forma de direito, pois 'o direito só pode consistir por natureza na aplicação de uma medida igual'. Mas como, por isso, a desigualdade natural de aptidões entre os indivíduos não é levada em consideração, o direito 'no fundo é, portanto, como todo direito, o direito da desigualdade'. Marx não menciona a a
}

25 Idem. p. 23. 
necessidade de um poder estatal que assegure pela coerção a realização destas normas de direito 'desigual' que mantém seus 'limites burgueses' mas, evidentemente, isto subentende-se"26

As referências de Marx utilizadas na citação acima transcrita são da obra "Crítica ao Programa de Gotha", escrito em 1875, como contraposição ao programa do partido operário alemão. Essa obra é tida por muitos como o escrito em que Marx chega mais perto de estabelecer uma teoria política prática de fato. Nesses escritos, o filósofo alemão esboça críticas ao direito burguês que foram usadas por muitos teóricos marxistas para justificar posicionamentos em relação ao direito, assim como Pachukanis.

Dessa maneira, o jurista soviético coloca a mediação jurídica como central para as relações de troca e as relações de troca como pressuposto da forma jurídica burguesa. $\mathrm{O}$ horizonte da crítica pachukaniana está na extinção do direito, não só do direito burguês ou do direito sob o capitalismo, mas sim do direito como um todo. A justificativa desse pensamento aparece da seguinte forma: "concluir-se que os tribunais e as leis deverão sempre existir, porque mesmo um estado de abundância econômica não fará desaparecer todos os delitos contra a pessoa, significa tomar os momentos secundários e derivados pelos momentos essenciais e fundamentais", ${ }^{27}$

Concordamos em parte com esse raciocínio, tendo em vista que a forma jurídica burguesa realmente não garante nada menos que a manutenção das estruturas de poder da sociedade capitalista, todavia entendemos que esse momento posterior só poderá ser alcançado com a sociedade de "abundância econômica" e, ainda assim, há pontos necessários de aprofundamento do debate e enquanto não chegamos a esse momento devemos encarar o direito como freio necessário. Não que o direito irá, por si só, garantir e impulsionar a emancipação humana, porém a não utilização de mecanismos normativos para criminalização dos movimentos sociais e a busca de instrumentos jurídicos de distribuição de renda, por exemplo, certamente garante pontos de avanço necessários a patamares civilizatórios de convivência humana.

26 Idem. p. 27.

27 Idem. p. 28. 
Há diversas formar de encarar o direito, sendo certo que algumas são matizes e acessórias de outras. Podemos identificar basicamente duas grandes visões: a primeira, que podemos encaixar no grande campo progressista, na qual o direito é encarado como instrumento de justiça social; e a segunda, que enxerga no direito apenas a manutenção do status quo e assim deve continuar. Certamente nos colocamos ao lado da primeira visão e assim desenvolvemos nosso estudo.

\section{II.4.2 - A luta pela emancipação}

O quadro traçado até aqui não é nada animador. A subordinação do trabalho ao capital; o processo de produção capitalista; a lógica mercantilizada que permeia as relações sociais que só fazem reproduzir o modo de produção; a opressão de classe; a geração de riqueza para poucos; enfim, o próprio capitalismo são elementos que podem nos fazer crer que a emancipação do ser humano reificado está muito longe ou é até impossível.

Ressalta-se, todavia, que o papel de quem consegue visualizar essas condições é pensar em um outro modelo, um outro mundo possível, sob pena de termos apenas teorias que são críticas de maneira etérea, que não fazem jus a tão famosa tese 11 de Marx a Feurbach. ${ }^{28}$ A constatação das ignomínias do capitalismo devem servir a um impulso de mudança, ao pensamento crítico verdadeiramente comprometido com quem sofre de maneira mais brutal as opressões constatadas. É nítido que a opressão de classe do capitalismo se dá por uma via de mão única, sendo certo que a classe oprimida é sempre a classe trabalhadora, e nesse sentido devemos entender sua luta pela emancipação.

Várias foram as tentativas ao longo do processo histórico de mudança do estado de coisas que o capitalismo determina. Várias foram as tentativas de reformas e revoluções. Entretanto, ainda vivemos no capitalismo. Devemos, porém, ter claro que foram conquistados muitos avanços: no campo do direito do trabalho, por exemplo, hoje temos uma visão muito mais progressista da legislação trabalhista - à exceção dos que pensam o direito do trabalho com o pé na direção da empresa - do que no começo do século XX, no qual sequer esse ramo era pensado de maneira sistemática e com autonomia didática, com alguns doutrinadores negando sua possibilidade de mera existência. Não podemos nos

28 "Os filósofos apenas interpretaram o mundo de diferentes maneiras; porém o que importa é transformálo". Com tradução da edição da Boitempo de a Ideologia Alemã. MARX, Karl. ENGELS, Friedrich. A ideologia alemã: crítica da mais recente filosofia alemã em seus representantes Feuerbach, B. Bauer e Stirner, e dos socialismo alemão em seus diferentes profetas. Trad. Rubens Enderle, Nélio Schneider e Luciano Cavini Martorano. Sâo Paulo: Boitempo, 2007. p. 539. 
furtar, todavia, de pensar dialéticamente, lembrando que os avanços são sempre acompanhados de perto pelos retrocessos. Muito se falou nas últimas décadas em flexibilização do direito do trabalho como forma de enfrentamento do problema da nova configuração da empresa, porém sempre em desfavor do trabalhador.

O que propomos é buscar uma interpretação para o direito do trabalho, inserido na lógica maior do ordenamento jurídico, que busque a efetiva melhoria das condições de vida da classe trabalhadora e que contribua para a justiça social de maneira clara e decisiva. Não estamos de maneira alguma nos furtando do debate sobre o real papel do direito na sociedade capitalista - até por isso fizemos os apontamentos precedentes que permeiam e irão permear todo o nosso estudo - mas sim propondo que atuemos, ainda que dentro de uma margem de atuação extremamente limitada, pois não podemos ficar parados assistindo a perda de gerações por conta da lógica perversa do capital tentando organizar uma revolução que não sairá do direito. O trabalho de organização política é fundamental, e o direito deve apoiá-lo, e não servir à criminalização dos movimentos politico-populares.

\section{II.4.3 - A busca de freios jurídicos}

Ainda que reconheçamos o caráter contraditório da luta por direitos, não podemos deixar que observar que, ao longo dos dois últimos séculos (XIX e XX) os movimentos populares, em sua maioria, sempre tiveram bandeiras ligadas à afirmação e efetivação de direitos como uma das formas de luta contra a opressão. Nesse sentido, podemos considerar que as lutas e os movimentos por afirmações de direitos contribuíram decisivamente para a construção de uma nova ordem social em contraposição à liberal outrora existente.

Dessa maneira, afirmamos o caráter positivo da mudança da orientação do Estado, de liberal para social, para as condições de vida e de luta da classe trabalhadora. Ainda que insuficiente, as novas estruturas de poder criadas com a finalidade da proteção social devem ser encaradas como um freio necessário para o processo de luta. Afinal, é melhor lutarmos contra um Estado democrático de direito que serve aos interesses da elite econômica do que lutarmos em um Estado autoritário pela formação do mesmo Estado democrático que hoje criticamos.

A construção do direito do trabalho como ramo autônomo das ciências jurídicas é, 
como veremos adiante, fruto de uma consciência social do direito em contraposição ao modelo liberal que impulsionava as instituições do século XIX e começo do século XX. Ao lidarmos com um direito que tem profundas raízes nesse campo social temos que ter claro a dimensão de suas normas e sua orientação enquanto instituição jurídica.

Ainda que o direito trabalhista não possua - como não poderia deixar de ser caráter revolucionário, existe a possibilidade de uma leitura, a partir da lógica dos direitos sociais, que favoreça uma concepção de sociedade de direito mais benéfica para os trabalhadores, fundada em preceitos de distribuição de renda e justiça social que busquem, em alguma medida, colocar-nos mais próximos de uma efetiva igualdade material.

Assim, com todas as limitações que uma leitura contra hegemônica do direito possui, consideramos que a busca por freios jurídicos à exploração, à miséria, enfim, a todo o estado de coisas de desumaniza o ser humano é benéfica e assim é que pretendemos dar a toada de nosso estudo. A partir daqui passemos a averiguar como uma colocação do problema sob esses pressupostos pode influenciar a leitura do direito. 


\section{III - A NECESSÁRIA PROTEÇÃO JURÍDICA}

\section{III.1 - Direito civil e direito do trabalho: o mito do trabalho livre}

É consenso que a formação do direito do trabalho como um ramo autônomo das ciências jurídicas é recente. É difícil, todavia, estabelecer um marco preciso sobre tal formação. A autonomia de um ramo do direito passa por vários aspectos: doutrinário, legislativo, juridiscional, didático etc. Ainda que eminentemente positivista - e avessa à nossa concepção de totalidade - a divisão das ciências jurídicas em ramos do direito possui um importante caráter pedagógico.

A separação positiva do direito em ramos é uma realidade. Cumpre fazermos a crítica, mas também nos aproveitarmos dos benefícios que podem ser extraídos para nossos objetivos. Dissecar a maneira como se estuda o real, nas ciências humanas - abstratas - é um passo fundamental para uma teoria que tenha lastro factual e não se perda em generalizações dantescas que apenas sirvam para fundamentar o que se esteja afirmando, seja lá o que for. A importância de um estudo do direito que compreenda a realidade concreta reside no fato de que o direito implica nas relações sociais e assim deve ser compreendido, caso contrário estaríamos fazendo uma espécie de "arte pela arte", direito pelo direito, sem comprometimento com a luta dos movimentos que afirmam a necessidade de um direito voltado para a realidade.

É isso que pretendemos fazer. Entender a afirmação do direito do trabalho como ramo autônomo naquilo que nos é benéfico, sem, entretanto, cairmos no fetiche do positivismo, que cria e recria a realidade a partir de segmentações múltiplas que perdem qualquer relação com a realidade e só servem aos interesses dos detentores da técnica.

Isso posto, temos que no campo legislativo as primeiras leis que regulam as relações de trabalho datam da segunda metade do século XIX, porém de maneira ainda incipientes. Um marco legislativo preciso só pode ser identificado no começo do século $\mathrm{XX}$, ainda sob o nome de legislação operária, obreira ou industrial. No campo do direito internacional, o fato mais importante que podemos destacar e que certamente influenciou de maneira decisiva os ordenamentos internos foi a criação, em 1919, da Organização 
Internacional do Trabalho (OIT) no âmbito do Tratado de Versalhes, que estabeleceu a ordem internacional após o fim da primeira grande guerra.

O aspecto doutrinário da autonomia do direito do trabalho como ramo do direito, contudo, é o que mais interessa nesse momento de estudo. Muitas são as avaliações - em sua maioria rasas e carentes de fontes - de que o direito do trabalho surgiu no contexto da revolução industrial que impôs condições limítrofes de trabalho a homens, mulheres e crianças. Esses mesmos autores afirmam que tais condições não eram mais suportadas pelos trabalhadores, que passaram a se organizar e lutar pela regulamentação das relações de trabalho. Como que consequência natural das pressões, o Estado impôs uma legislação trabalhista que protegesse o trabalhador fraco da tirania de seu capataz.

Essas avaliações, além de não indicarem dados concretos que levaram a essas conclusões misturam indícios de realidade com uma assustadora naturalização do desenvolvimento histórico. A história não é feita de uma relação de causas e consequências, tão simples quanto querem fazer crer. $O$ elemento da política foi fundamental para a construção do direito do trabalho, não porque os trabalhadores "sentindo-se" explorados resolveram lutar por seus direitos, mas porque muito mais a organização coletiva dos indivíduos que trabalham fez avançar sua consciência de classe e tornou possível um questionamento para além do aperto de parafusos.

$\mathrm{O}$ erro fundamental dessas teorias é o entendimento do todo a partir de um elemento isolado e que, apesar da aparência, não pode ser levada a efeito como fator redutor chave da totalidade. Assim, não podemos concordar com as teorias que reduzem a formação do direito do trabalho ao resultado de lutas de trabalhadores que, como um estalo, passaram a não gostar mais das condições de trabalho que lhes eram impostas. Essas teorias fazem apenas uma parte do caminho da reconstrução do concreto - se é que fazem - pois apesar das lutas sociais representaram importante papel na formação e afirmação do direito do trabalho, elas não surgiram, tão somente, a partir da percepção dos trabalhadores de que eram explorados. Muitos outros fatores devem ser levados em consideração nessa análise e, via de regra, não são, como, por exemplo, a necessidade de formação de um mercado consumidor e a racionalização na organização do trabalho 
Voltando à doutrina, podemos afirmar sem margem de erro, que a primeira obra brasileira que cuidou da questão trabalhista foi os "Apontamentos de Direito Operário" de Evaristo de Moraes, publicado originalmente em 1905. Tal obra é tão pioneira que veio até mesmo antes de seus congêneres europeus que escreveram sobre legislação industrial.

Como esse tópico trata da relação entre direito civil e direito do trabalho, iremos buscar em autores do direito privado referências sobre direitos sociais que influenciaram de maneira decisiva o desenvolvimento do direito do trabalho como ciência jurídica.

Nesse contexto destacamos o título "A nova phase do direito civil em suas relações econômicas e sociaes", publicado no Brasil em 1900. Nela, o autor começa por escrever que o direito civil precisava ser revisto e readequado à nova realidade social configurada com a efervescência da virada do século XIX para o século XX. Enrico Cimbali, italiano, foi um dos primeiros teóricos do direito civil a se debruçar especificamente sobre a tutela das relações de trabalho como objeto diferenciado do direito privado.

Até então, as relações de trabalho estavam inseridas no campo do direito civil, tendo em vista que se considerava que o trabalhador, ao vender sua força de trabalho ao seu tomador de serviços, estabelecia uma relação contratual de compra e venda - quando não de locação - que deveria receber o mesmo tratamento do direito que uma compra e venda qualquer. Cimbali, discordando de tais premissas, escreve uma obra pioneira e com força arrebatadora para os padrões do direito civil da época.

No processo legislativo de tutela das relações de trabalho foram, aos poucos, e de maneira muito tímida, surgindo algumas leis esparsas nos países da Europa ocidental que visavam regular tais relações e tirá-las do contexto das relações jurídicas de direito civil. Comentando essas legislações esparsas, Cimbali afirma:

\footnotetext{
“A ação do Estado, assim considerada, não é de simples tutela, mas de integração e organização entre as várias classes da sociedade; e como tal não tende somente a regular o trabalho das creanças nas minas e nas fábricas, como regula igualmente o trabalho das mulheres e dos adultos em suas várias formas de manifestação. Este necessita de mais larga e directa ingerência do Estado, segundo o ideal germânico, nas determinações do contracto de trabalho, em contradição com o princípio da liberdade absoluta estabelecida no Código Civil;
} 
também se começou a sentir com o desenvolvimento da grande indústria"29

Antes de analisarmos o conteúdo pioneiro contido na transcrição acima, é necessário que façamos a crítica. Ao considerar que a ação do Estado deve ser de “integração e organização entre as várias classes da sociedade" o autor parte de um pressuposto com o qual não podemos de forma alguma concordar: o caráter de conciliação de classe dado do Estado não representa o ideal de organização social que buscamos.

Mesmo se adotarmos tal premissa como entendimento meramente descritivo, e não ideológico, também não podemos concordar. O Estado representa os interesses da classe dominante. Nesse sentido, no utilizamos de uma muito conhecida passagem de Marx contida em "A Ideologia Alemã” que ilustra bem esse pensamento:

\footnotetext{
“As idéias da classe dominantes são, em cada época, as idéias dominantes, isto é, a classe que é a força material dominante da sociedade é, ao mesmo tempo, sua força espiritual dominante" ${ }^{, 30}$
}

Com essa passagem, Marx destrói categoricamente um dos maiores mitos da modernidade, o mito de que o Estado busca o bem comum e o interesse geral. Podemos ir além e afirmar que essa mesma passagem, acaba com o mito da imparcialidade que permeia não só o direito mas quase todos os ramos das ciências humanas, que diz que é possível ao agente atuar de forma imparcial e independente, buscando a equidistância entre ideias antagônicas e fazendo uma análise isenta. Como isso não é possível, é sempre necessário buscarmos o ideal determinante por trás de cada pensamento.

Assim, não podemos coadunar com a ideia de integração entre as classes sociais e o papel do Estado nesse sentido. Contudo, é inegável que o direito do trabalho possui um caráter de organização das forças produtivas e assim pode ser encarado. Isso posto, voltemos à análise do texto de Cimbali .

No supracitado trecho, o autor afirma que o contrato de trabalho não pode ser

29 CIMABALI, Enrico. A nova phase do Direito civil em suas relações econômicas e sociaes. Rio de Janeiro: Livraria Clássica. 1900. pp. 74/75.

30 MARX, Karl. A ideologia alemã: crítica da mais recente filosofia alemã em seus representantes Feuerbach, B. Bauer e Stirner, e do socialismo alemão em seus diferentes profetas (1845-1846)/Karl Marx, Friedrich Engels: supervisão editorial, Leandro Konder; tradução, Rubens Enderle, Nélio Schneider, Luciano Cavini Martorano. São Paulo: Boitempo, 2007. p. 47 
regido pelos princípios de liberdade que informam o código civil. Esse fato é de extrema relevância para nosso estudo, marcando uma passagem do pensamento civilista clássico para um pensamento que iria, mais tarde, desembocar na teoria do direito social.

Quando o autor afirma que também se começou a sentir a necessidade de intervenção estatal nas relações de trabalho com o desenvolvimento da grande indústria, ele estava se referindo diretamente ao período pós revolução industrial, quando os países europeus passaram por um forte processo de industrialização e criou-se um contingente enorme de operários que precisavam da tutela estatal. O número de operários, trabalhadores assalariados, cresceu vertiginosamente em poucos anos nos países que sofreram os impactos da revolução industrial. Assim, havia uma demanda real na sociedade de enquadramento jurídico das relações de trabalho firmadas no âmbito da indústria.

Durante algum tempo estabeleceu-se um embate entre os teóricos do direito sobre qual seria o grupo de normas aplicáveis a esses casos. De um lado, posicionavam-se doutrinadores que queriam que o contrato de trabalho fosse regulado pelas normas do Código Civil e, de outro, teóricos que entendiam tratar-se de uma situação especial que merecia uma tutela diferenciada por parte do estado. Evaristo de Moraes, em seus apontamento já aludidos, resume a questão da seguinte maneira:

\footnotetext{
“Os economistas clássicos mantém ainda, contra a evidência dos fatos, no interesse do capitalismo moderno, a crença nas virtudes de liberdade do trabalho, não admitindo regras, nem mesmo legais, que fixem as bases do contrato de trabalho entre o empregador e o empregado, ou (como se diz na linguagem jurídica brasileira) entre o locatário e o locador de serviços. O homem é livre argumentam; tem o direito de vender o seu trabalho pelo preço e nas condições que quiser. Mas, na vida industrial moderna, essa liberdade de trabalho só tem gerado a opressão e a miséria"31
}

Notemos que o autor fez questão de frisar como a linguagem jurídica brasileira da época se referia a empregado e empregador: locador e locatário de serviços. Claramente temos aqui um exemplo da visão civilista, impregnada na forma de tratamento das relações de trabalho. E ainda com um grave erro de avaliação: o trabalhador vende sua força de trabalho, transformada em mercadoria pelo capitalismo, jamais podendo admitir-se tratar

31 MORAES, Evaristo de. Apontamentos de direito operário. $4^{\mathrm{a}}$ ed. São Paulo: Ltr, 1998. p. 9. 
de uma locação. Ou por acaso o trabalhador pode pedir de volta o seu trabalho depois que o empregador o utilizou? A locação da força de trabalho é um conceito tão absurdo que o próprio direito tratou de esquecê-lo ao longo do tempo, mas demonstra bem a mentalidade atrasada com a qual um dia se pensou lidar com as relações de trabalho.

Voltando ao teórico do direito civil, destacamos por fim uma passagem de sua obra em que o autor afirma a necessidade da criação de uma nova mentalidade jurídica, capaz de abarcar as relações entre capital e trabalho sob uma ótica diferente do que sempre fora feito. Vejamos:

“A intervenção da lei torna-se necessária para proteger o opprimido do oppressor, e o oppressor dos opprimidos; em outras palavras, para preservar a integridade da vida humana da cobiça dos patrões, e ao mesmo tempo os legítimos interesses dos patrões dos ódios ferozes e vinganças (...) E toda uma série de relações novas relativas a propriedade e aos direitos especiaes producto das indústrias, com relação à personalidade humana em sua integridade physica e moral, à duração do trabalho, à quantia dos salários, à responsabilidade nos casos de infortúnio, à observância, finalmente, das condições a que estão submettidos respectivamente patrões e operários, merece ser regulamentada por preceitos correspondentes" ${ }^{\prime 32}$

A importância histórica desses escritos é inegável. Alguém que, na virada do século XIX para o século XIX, conseguiu esboçar um pensamento crítico ao direito civil como regulamentador das relações de trabalho certamente influenciou de maneira decisiva a construção do direito do trabalho tal qual o entendemos hoje.

Novamente aqui se faz necessário pontuar a crítica sobre o entendimento de conciliação de classe que o autor impõe à tutela das relações de trabalho. Ainda que, no limite, as regras de direito do trabalho possuam muito desse caráter conciliador não é isso que pretendemos afirmar. Colocamos o direito do trabalho no centro das disputas sociais e consideramos que sua formulação crítica é fundamental, ainda que não decisiva, para o avanço na luta de classes.

Ainda que não concordemos com a perspectiva conciliatória proposta por Cimbali, um dado é inegável: o direito do trabalho não serve apenas aos interesses do trabalhador, 32 Op. cit. p. 79. 
mas também a dita proteção do patrão contra os "ódios ferozes e vinganças". Ainda que não seja exatamente o papel da legislação trabalhista, é inegável que as normas de tutela das relações de trabalho exercem um papel fundamental na organização da produção capitalista. Exercer papel na organização da produção significa estabelecer limites e regras claras para a produção, ou seja,estabelecer quantas horas um trabalhador deve laborar por dia, além de representar um benefício ao empregado - que não fica mais à mercê da super exploração pelas horas de trabalho - também é a imposição de ditames racionais para a produtividade capitalista. Hoje parece banal afirmar isso, mas é óbvio que dois trabalhadores trabalhando 8 horas são muito mais produtivos e lucrativos para o capitalista, do que um que labora 16 horas seguidas.

Outro autor que despertou nossa especial atenção foi o português Abel de Andrade, descrito por Evaristo de Moraes, em seus apontamentos, como um "jovem civilista português, que revela ilustração pouco comum”. Tal autor publicou, em 1898, um livro chamado "A vida do direito civil" em que expõe, com erudição realmente inusual, seu pensamento sobre as tendências do direito civil à época e como haveriam de se portar os legisladores e doutrinadores sobre o assunto.

O autor reserva boa parte do opúsculo I de sua obra a tecer críticas a teoria de Karl Marx, que havia publicado a primeira edição de "O Capital" menos de duas décadas antes, bem como as chamadas doutrinas socialistas. Discordamos de quase tudo que o autor expõe do ponto de vista metodológico, principalmente quando sugere a solução da conflito de classe a partir do viés da conciliação, afirmando que o Estado está acima das disputas de classe e que deve servir ao interesse público em primeiro lugar.

Verdadeiramente, é difícil enquadrar o autor dentro de uma ou outra escola do pensamento, chamando-o de liberal, corporativista ou de teórico crítico. Contudo, sua crítica voraz, seu franco debate com os socialistas e sua teoria demonstram uma capacidade de lidar com o diverso não como um tabu, coisa que o direito contemporâneo definitivamente não possui mais.

Essas breves palavras sobre Abel de Andrade servem para contextualizar um autor que escreveu sobre a necessidade de regulamentação das relações de trabalho sob um viés 
protetivo, em 1898. Porém, não podíamos fazer apologia de seu pensamento sem nos posicionarmos sobre o que ele representa para a teoria geral do direito, sob pena de estarmos sendo intelectualmente desonestos. Pois bem, isso posto vamos ao que nos interessa de fato, que é a forma como o autor colocou o problema da tutela das relações de trabalho em sua época, sem, contudo, deixarmos de pontuarmos a crítica quando necessário.

Senão vejamos: "Em harmonia com esses princípios convém limitar a liberdade contractual da prestação de serviços com certas providencias tendentes a fazer desapparecer a extorsão do operário pelo patrão, inaugurando o império da equidade". ${ }^{33}$ Afora o fato de que o autor considera que apenas com a intervenção do estado, através de leis de tutela das relações de trabalho, seria possível acabar com a "extorsão do operário pelo patrão", a importância histórica desses escritos reside no fato de que mesmo sendo ele um teórico do direito civil - com suas inclinações ideológicas questionáveis - ele demonstra, em 1898, uma clara preocupação com a questão do trabalho.

Dentre as medidas que ele propõe como forma de mitigar a chamada extorsão, estão: a criação de salários mínimos, limitação da jornada de trabalho, proibição do trabalho de crianças, limitação do trabalho de adolescentes, responsabilização dos patrões por acidentes sofridos pelos empregados em serviço e por último, e talvez mais importante, a criação de uma justiça especializada para a solução dos conflitos advindos da aplicação dessas leis ${ }^{34}$. O autor, com isso, propunha uma atualização do direito civil para os novos tempos.

Mesmo que suas propostas fiquem no âmbito do direito civil, é inegável o caráter pré trabalhista de seus escritos. Ao propor uma justiça especializada para dirimir conflitos oriundos das relações de trabalho - reitera-se, em 1898 - o autor coloca-se como um dos grandes defensores de uma legislação social já no século XIX.

$\mathrm{Na}$ verdade, essa nossa reflexão sobre a regulamentação das relações de trabalho a partir da lógica de um direito "especial" - diferente do direito civil - serve para identificar que, mesmo nos teóricos do direito privado que entendiam que as relações de trabalho

33 ANDRADE, Abel. A vida do direito civil: opúsculo I. Coimbra: Imprensa da universidade, 1898. p. 97. 34 Idem. p. $97-98$ 
deveriam ser tuteladas pelo Estado de maneira mais "enérgica", havia o consenso de que não existe trabalho livre. Ainda que muito longe de qualquer inspiração marxista, muitos desses pensadores identificavam o caráter subordinado do trabalho aos interesses do capitalista, não concebendo um mercado de trabalho tal qual uma feira livre em que possuidores de bananas vendiam para quem quisesse comprar pelo preço dado pelo vendedor.

A situação é muito mais complexa, e nos espanta ainda hoje existirem pensamentos no sentido de que o trabalhador só trabalha porque quer, e que assim sendo a legislação deveria facilitar a relação de trabalho para beneficiar a produção e não criar "entraves" a contratação "livre" entre patrões e empregados. Pois bem, marcamos nossa posição no sentido contrário. Achamos necessária uma legislação trabalhista cada vez mais protetiva ao trabalhador, a fim de estabelecer limites claros à super exploração, sob risco de coadunarmos com a barbárie.

Por exemplo, está se difundindo cada vez mais em alguns ramos de atuação profissional o que convencionou-se chamar de "CLT Flex", modalidade de contratos de trabalho em que o trabalhador assina um contrato celetizado, com certa remuneração e recebe o restante diretamente do empregador em parcelas que não integram seu salário, o chamado "por fora".

Por parte dos patrões essa modalidade de contrato visa claramente à burla de direitos trabalhista que, teoricamente, oneram a folha de pagamento e inviabilizam a contratação de empregados formais. Por outro lado, o trabalhador aceita tais condições pelo temor de não conseguir outro trabalho e perder sua fonte de sustento. Esse é o tão chamado mercado livre de trabalho, em que as partes acordam as condições do contrato como bem entendem. Contudo, não identificamos aqui qualquer liberdade contratual, pelo menos não ao lado do empregado, que por não possuir força econômica assume uma condição que não lhe é benéfica, temendo não conseguir outro trabalho.

Não é a isso que o direito do trabalho serve. Já afirmamos a limitação da liberdade de contratar nas relações de trabalho como elemento fundamental de uma sociedade em que o pacto de solidariedade se funda no respeito aos diretos humanos e à valorização da 
condição do trabalhador. Qualquer entendimento em contrário não deve ser aceito sob o ponto de vista do valor social do trabalho.

\section{III.2 - A regulação das relações de trabalho sob a ótica da proteção social}

O processo de formação da proteção social trabalhista, como qualquer processo histórico, é complexo e dinâmico. A incorporação estatal dessa nova legislação mostra-se cheia de matizes e nuances do momento histórico específico em que essa legislação surgiu, a ponto de ser organizada, por Evaristo de Moraes Filho ${ }^{35}$, da seguinte forma:

\footnotetext{
“Os motivos que levaram o Estado a dar esse passo decisivo na história dos destinos humanos podem ser sumariados, didaticamente, da seguinte maneira: 1) os vícios e as conseqüências da liberdade econômica e do liberalismo político; 2) o maquinismo; 3) a concentração de massas humanas e de capital; 4) as lutas de classes, com as conseqüentes rebeliões sociais; 5) os livres acordos entre grupos profissionais; 6) a encíclica papal Rerum Novarum; 7) a guerra (1914-1918)”.
}

Fruto de lutas e conquistas dos trabalhadores, mas também de uma necessária regulamentação para otimizar os fatores de produção, o direito do trabalho começa então a se construir como ramo autônomo do Direito.

As lutas sociais na primeira metade do século XX no Brasil, ainda que incipientes em relação a uma Europa onde estava ocorrendo a Revolução de 1917, influenciaram o movimento operário com ideais anti-burgueses. As primeiras greves no Brasil, por exemplo, foram organizadas pelos trabalhadores fortemente influenciados pelas ideias anarquistas de alguns imigrantes italianos, a ponto de uma das nossas primeiras leis em matéria sindical tenha sido a chamada "Lei Celerada", de 1927, que facilitava a expulsão do país de imigrantes envolvidos com a atividade sindical.

Nesse sentido, os ideais anarquistas, socialistas e anti-liberais de forma geral tiveram grande importância para o surgimento do movimento social dos trabalhadores no Brasil. Assim, não podem ser desprezadas toda a sorte de lutas políticas e sociais que impulsionaram a criação da legislação trabalhista no Brasil e no mundo. Retirar-lhe esse caráter histórico é corroborar com a tese de desvalorização do Direito do Trabalho, considerado anacrônico e prejudicial ao desenvolvimento econômico.

35 MOREAS FILHO, Evaristo. Tratado elementar de Direito do Trabalho. $2^{\mathrm{a}}$ ed. Rio de Janeiro: Freitas Bastos, 1965. 
Buscamos, ao dividirmos nosso estudo, até o presente momento, sobre a formação do direito do trabalho a partir da visão civilista sobre a matéria e posteriormente com a tutela das relações de trabalho sob a ótica dos direitos sociais, dar o enfoque histórico necessário ao estudo desse ramo do direito. Como já ficou claro, o caráter histórico e determinado do direito permeia todo o nosso estudo, com maior ou menos peso. Ao colocarmos o direito tal qual como conhecemos como fruto do capitalismo, conforme fizemos no começo de nosso estudo, e agora enfrentando a questão do direito do trabalho como fruto de lutas e conflitos sociais, queremos afirmar o conteúdo dialético e contraditório de nosso objeto de estudo como impulsionador de seu progresso e evolução.

Mais do que isso, buscamos marcar posição frente a um pensamento muito difundido na academia de direito, ainda em nossos tempos, de que o direito do trabalho é fruto de uma dinâmica jurídica que despreza os valores sociais. Especificamente no caso brasileiro, temos um pensamento muito forte de que a legislação trabalhista é corporativista por ter sido "criada" por Getúlio Vargas, com inspiração no direito do trabalho fascista.

Nesse sentido, podemos citar Jorge Luiz Souto Maior:

\begin{abstract}
"Alguns autores, todavia, afirmam que as leis trabalhistas brasileiras foram fruto da mente fascista de Vargas, não tendo sido precedidas da lutas de corpo e de idéias, como ocorrera na Europa Ocidental. O Estado ter-se-ia antecipado aos fatos, direcionando a conduta nas relações de trabalho, sem que uma reivindicação nesse sentido tivesse ainda emergido da sociedade. (...) Não é fato, no entanto" e completa que "Com Vargas repete-se no Brasil a mesma história já vivida na Europa, a proliferação de leis trabalhistas, mas a sua fonte material preexistiu ao período Vargas" ${ }^{36}$.
\end{abstract}

Assim temos que a legislação trabalhista possui forte conteúdo social, de proteção do trabalhador hipossuficiente, rechaçando, portanto, qualquer tentativa de configuração do direito do trabalho a partir da livre contratação entre empregados e empregadores. Podem parecer, para alguns, óbvias essas nossas afirmações, porém é importante fazê-las para dar o escopo necessário ao nosso método de estudo.

36 MAIOR, Jorge Luiz Souto. O direito do Trabalho como instrumento de Justiça Social. São Paulo: LTr, 2000. p. 68 


\section{III.3 - A configuração da relação de emprego}

A relação de emprego é a base incidental de todo o direito do trabalho, já que as normas previstas na CLT, em sua esmagadora maioria, são aplicáveis aos trabalhadores que prestam serviços sendo pessoas físicas, sem se fazer substituir por outrem, mediante salário, de maneira habitual e sob a subordinação de um poder diretivo. Basicamente resumimos os elementos caracterizadores da relação de emprego, que fazem um trabalhador ser empregado de outrem, conforme está previsto no artigo $3^{\circ}$ da Consolidação das Leis do Trabalho. ${ }^{37}$

Não é a toa que essa relação é a base incidental do direito do trabalho. Como ramo do direito que visa a tutelar as relações entre o capital e o trabalho, a normatividade trabalhista encontrou na relação de emprego a forma típica através da qual se desenvolve a compra e venda de mão de obra. Nesse sentido, Souto Maior escreve que "a relação de emprego é a expressão jurídica que traduz uma das fases da evolução da exploração do trabalho alheio: o trabalho assalariado." 38

Assim, devemos nos debruçar sobre o cerne da questão, qual seja, o trabalho assalariado e sua expressão jurídica, que é a relação de emprego. Sob o capitalismo, a caracterização do trabalho assalariado está intimamente ligada com a forma de organização da produção. Essa organização é a expressão que o capitalista imprime à sua planta produtiva, no sentido de melhor conduzir o trabalho alheio para o fim específico da produção de mercadorias.

Do ponto de vista clássico, a relação de emprego é a expressão jurídica de uma relação entre empregado e empregador, capitalista e operário, na qual um comanda a produção e o outro produz. Ainda que hoje em dia muito se busque uma nova teoria para o trabalho, e mesmo para o direito do trabalho, em que a relação de emprego fique em segundo plano, é importante lançarmos uma perspectiva crítica sobre a organização da produção, na medida em que ela representa o substrato fático de um dos objetos de nosso estudo.

37 Art. $3^{\circ}$ - Considera-se empregado toda pessoa física que prestar serviços de natureza não eventual a empregador, sob a dependência deste e mediante salário.

38 SOUTO MAIOR, Jorge Luiz. Relação de Emprego \& Direito do Trabalho: no contexto da ampliação da competência da justiça do trabalho. São Paulo: LTr, 2007. p. 51 


\section{III.3.1 - Organização do trabalho e da produção: a gerência científica}

Para lançarmos uma visão sobre a gerência científica, nos apoiaremos na grande obra de Harry Braverman, "Trabalho e capital monopolista: a degradação do trabalho no século XX", na qual o autor dedica um capítulo específico ao tema que agora estamos abordando.

Braverman conceitua a gerência científica da seguinte maneira: "A gerência científica, como é chamada, significa um empenho no sentido de aplicar os métodos da ciência aos problemas complexos e crescentes do controle do trabalho nas empresas capitalistas em rápida expansão". ${ }^{39}$ A partir dessa rápida passagem, que caracteriza o que para Braverman pode ser considerado um conceito de gerência científica, podemos identificar de maneira clara uma relação entre a organização da produção com base científica e o emprego.

Aplicar os métodos da ciência no controle do trabalho implica em garantir, de maneira eficaz, que o trabalhador se mantenha subordinado a uma estrutura fabril, ou seja, a um poder de controle do empregador, o que é um dos requisitos fundamentais da relação jurídica de emprego.

Braverman centra seus esforços no estudo da gerência científica em Frederick Taylor, que inaugurou um modo de organização da produção amplamente difundido, conhecido por taylorismo: um modelo de gerência do trabalho intrinsecamente ligado à forma fordista de produção e que durante muito tempo foi hegemônico nas linhas fabris, até a sua crise na década de 70 e o começo do que ficou conhecido como a transição pósfordista.

Por ora vamos nos ater à análise de Braverman sobre a gerência científica. Ele afirma que Taylor, ao contrário do que alguns estudiosos afirmavam, dizendo que ele criara uma ciência do trabalho, pretendia uma "uma ciência do trabalho dos outros" e buscava "uma resposta ao problema específico de como controlar melhor o trabalho alienado - isto é, a força de trabalho comprada e vendida". ${ }^{40}$

39 BRAVERMAN, Harry. Trabalho e capital monopolista: A Degradação do Trabalho no Século XX. Trad. de Nathanael C. Caixeiro. $3^{a}$ ed. Rio de Janeiro: Guanabara. 1974. p. 82.

40 Idem. pp. 85-86. 
Nesse momento, fica claro que a gerência científica - ao menos o modelo que Taylor inaugurou - não pretendia ser a otimização de qualquer trabalho, no sentido de dispêndio de força humana para interação com a natureza, com o fito de incrementar a produção. As técnicas e métodos propostos pela gerência científica tinham objetivo claro e imediato: melhorar a forma como o trabalho era exercido sob o capitalismo, gerando cada vez mais riqueza e proporcionado cada vez mais lucro para o capitalista.

O modelo de Taylor aprofundou ainda mais as relações entre trabalhadores e o poder de direção exercido pelo empregador dentro da empresa. Bravernan afirma:

\footnotetext{
"Um trabalhador está sob controle gerencial quando sujeito a essas normas oi a qualquer de suas extensões e variações. Mas Taylor elevou o conceito de controle a um plano inteiramente novo quando asseverou com uma necessidade absoluta para a gerência adequada a imposição ao trabalhador da maneira rigorosa pela qual o trabalho deve ser executado (...) Seu 'sistema' era tão somente um meio para que a gerência efetuasse o controle do modo concreto de execução de toda atividade no trabalho. desde a mais simples à mais complicada. Nesse sentido, ele foi o pioneiro de uma revolução muito maior na divisão do trabalho que qualquer outra havida" ${ }^{\$ 1}$
}

Mais do que aprofundar, podemos afirmar que a gerência científica criou um modelo sistemático de caracterização do poder de direção do empregador nos moldes do que conhecemos, e até mesmo nos moldes como o direito do trabalho conhece. Afinal de contas, Taylor iniciou seus escritos em 1880, sendo que o ápice de sua produção se deu em meio a passagem de século XIX para o XX, e seus métodos começaram a ser amplamente praticados pela empresas a partir de então. Justamente o período que identificamos como o dos primeiros passos para a autonomia do direito do trabalho face o direito civil.

A partir do momento em que temos clara a significação da gerência científica para sua época, devemos analisar qual seu papel dentro da organização do trabalho e da produção. Ainda com base na obra de Braverman, identificamos três princípios norteadores do modelo de Taylor que nos serão úteis para a identificação do papel da gerência científica.

O primeiro princípio preceitua basicamente que a execução do trabalho deve ser 41 Ibidem 
toda receitada pela gerência, independentemente do conhecimento do trabalhador sobre determinada arte ou ofício. O capitalista deve conhecer o trabalho a ser executado e alocálo da melhor maneira possível e não os trabalhadores:

"Podemos chamar a este princípio de dissociação do processo de trabalho das especialidades dos trabalhadores. O processo de trabalho deve ser independente do ofício, da tradição e do conhecimento dos trabalhadores. Daí por diante deve depender não absolutamente das capacidade dos trabalhadores, mas inteiramente das políticas gerenciais" ${ }^{\prime 2}$

O segundo princípio é ainda mais taxativo quando se trata do papel do trabalhador no processo de trabalho. É o chamado princípio da separação de concepção e execução. “A primeira implicação deste princípio é que a 'ciência do trabalho' de Taylor nunca deve ser desenvolvida pelo trabalhador", ${ }^{43}$

Ou seja, a gerência deve se encarregar de tudo deixando ao trabalhador "apenas" o ofício do trabalho, obedecendo a regras impostas pela gerência. E a justificativa que Taylor dá para isso, segundo Bravernan, faz todo o sentido dentro da lógica capitalista da produção:

\footnotetext{
"Taylor, no caso, argumenta que o estudo sistemático do trabalho e os frutos do estudo pertencem à gerência pela mesmíssimas razões que máquinas, imóveis, instalações etc. pertencem a eles; isto é, custa tempo de trabalho empreender tal estudo, e apenas os possuidores de capital podem arcar com tempo de trabalho"44
}

Tal argumento lembra o desenvolvido antigamente pelos pensadores gregos, que afirmavam que somente alguns poderiam participar da democracia da pólis, porque todo o restante da população precisava trabalhar. Esse pensamento, além de extremamente perverso, mascara o fato que a gerência deve pensar a organização do trabalho apenas porque essa organização se dá em seu interesse. Obviamente, se fosse possível uma gerência pensada por trabalhadores, essa perderia sua característica fundamental de gerência para ser uma autogestão que não se daria em benefício de ninguém mais que os próprios trabalhadores organizados.

42 Idem. p. 103.

43 Idem. p. 104.

44 Idem. p. 106. 
O terceiro princípio é a cereja do bolo da alienação. Caracterizado por Braverman como "a utilização deste monopólio do conhecimento para controlar cada fase do processo de trabalho e seu modo de execução" ${ }^{45}$, esse último princípio tem a função de criar trabalhadores que sejam peças de uma engrenagem que podem servir em qualquer lugar. Um trabalhador completamente alienado que está tão estranho ao seu trabalho que pode exercer qualquer ofício que lhe for demandado: "Era para garantir que, à medida que os ofícios declinassem, o trabalhador mergulhasse ao nível da força de trabalho geral e indiferenciado, adaptável a uma vasta gama de tarefas elementares, e a medida que ciência progredisse, estivesse concentrada nas mãos da gerência". ${ }^{46}$

Assim, pudemos constatar que a gerência nada mais é que uma ciência da alienação, preocupada com a criação de trabalhadores massa, que sirvam aos interesses do capitalismo sem questionar absolutamente nada. Além da importância dessa compreensão da gerência para o bom entendimento do que o direito chama de poder de controle do empregador, também pudemos entender como se dá a subordinação do trabalhador a partir do ponto de vista de quem emprega a força de trabalho. Nesse sentido é importante lutarmos pela afirmação de direitos a partir das contradições que a realidade no impõe. Obviamente queremos o fim da subordinação do trabalho ao capital, mas afirmarmos isso como palavras vazias que carecem de conteúdo para melhor explicação em nada contribui para a crítica, não à toa um dos discursos mais fortes da gerência moderna é o fim da subordinação, com empregados "parceiros" e "colaboradores". Esse discurso mascara a realidade e que deve ser combatido.

\section{III.4 - O elemento subordinação como fonte primária de direitos}

A definição das figuras requisito da relação de emprego se encontra nos artigos $2^{\circ} \mathrm{e}$ $3^{\circ}$ da CLT. $^{47}$ De tais definições, pode-se extrair as características básicas das figuras do

45 Idem. p. 108.

46 Idem. p. 109.

47 Art. $2^{\circ}$ - Considera-se empregador a empresa, individual ou coletiva, que, assumindo os riscos da atividade econômica, admite, assalaria e dirige a prestação pessoal de serviço.

$\S 1^{\circ}$ - Equiparam-se ao empregador, para os efeitos exclusivos da relação de emprego, os profissionais liberais, as instituições de beneficência, as associações recreativas ou outras instituições sem fins lucrativos, que admitirem trabalhadores como empregados.

$\S 2^{\circ}$ - Sempre que uma ou mais empresas, tendo, embora, cada uma delas, personalidade jurídica própria, estiverem sob a direção, controle ou administração de outra, constituindo grupo industrial, comercial ou de qualquer outra atividade econômica, serão, para os efeitos da relação de emprego, solidariamente responsáveis a empresa principal e cada uma das subordinadas.

Art. $3^{\circ}$ - Considera-se empregado toda pessoa física que prestar serviços de natureza não eventual a empregador, sob a dependência deste e mediante salário. 
empregado e do empregador. Empregador, na definição de Amauri Mascaro Nascimento é “todo ente para quem uma pessoa física prestar serviços continuados, subordinados e assalariados. É por meio da figura do empregado que se chegará à do empregador, independentemente da estrutura jurídica que tiver" ${ }^{\text {"48 }}$.

Empregador, portanto, é aquele que contrata empregados. Como bem afirmou Amauri Mascaro, é por meio do empregado que se chega à figura do empregador. Mais uma vez citando o Professor, "empregado é a pessoa física que com ânimo de emprego trabalha subordinadamente e de modo não-eventual para outrem, de quem recebe

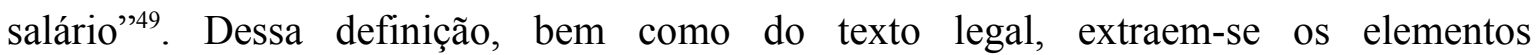
caracterizadores da relação de emprego, quais sejam: a prestação de serviços por pessoa física, com pessoalidade (intuitu personae), de forma não-eventual, com onerosidade e subordinação.

Os referidos elementos devem concorrer concomitantemente para que o vínculo entre empregado e empregador se aperfeiçoe, tornando-se relação de emprego. Assim, o trabalhador que presta serviços sob apenas uma daquelas condições, não será empregado típico.v. Mauricio Godinho Delgado, sobre esses elementos característicos do vínculo empregatício, escreve que "o fenômeno sóciojurídico da relação de emprego deriva da conjugação de certos elementos inarredáveis (elementos fático-jurídicos), sem os quais não se configura a mencionada relação" ${ }^{\text {50 }}$. Dessa forma, faz-se necessário analisar cada elemento separadamente, a fim de chegarmos ao ponto culminante da subordinação jurídica.

Primeiramente, ressalta-se que a prestação de serviços por pessoa física decorre da natureza pessoal da relação de emprego. Assim, para fins da incidência da tutela justrabalhista, a própria pessoa do trabalhador é o empregado e não determinada empresa, f. Percebe-se que diversas fraudes ao direito do trabalho recaem sobre esse elemento, sendo certo que não é raro conhecermos alguma situação na qual o empregado foi “obrigado a abrir uma firma” para poder prestar serviços a outrem. O objetivo disso é

Parágrafo único - Não haverá distinções relativas à espécie de emprego e à condição de trabalhador, nem entre o trabalho intelectual, técnico e manual.

48 NASCIMENTO, Amauri Mascaro. Curso de Direito do Trabalho. 14 ed. São Paulo: Saraiva, 1997. p. 425

49 Idem. p. 380

50 DELGADO, Mauricio Godinho. Curso de Direito do Trabalho. $5^{\text {a }}$ ed. São Paulo: LTr, 2006.. p. 290 
claro: desrespeitar os direitos do trabalhador. Por isso, constatada a fraude, não há porque - à luz da primazia da realidade - não haver o reconhecimento do vínculo empregatício entre o prestador de serviços e o seu tomador.

A pessoalidade, segundo elemento analisado, está intrinsecamente ligada ao anteriormente discutido. Prestar serviços com pessoalidade implica a pessoa física realizar as tarefas para as quais foi contratada intuitu personae, ou seja, não podendo se fazer substituir por outrem. Assim, a prestação de serviços é pessoal na medida em que o empregado é identificável. É sempre ele, salvo exceções justificadas, quem realiza o trabalho.

Dessa forma, as obrigações decorrentes da pessoalidade se aplicam também ao empregador. Se um trabalhador presta serviços com pessoalidade, e estão presentes os demais requisitos da relação de emprego, o empregador deve tratá-lo como empregado. Percebe-se que se ele for tratado pelo empregador como um autônomo ou eventual, certamente estaremos diante de uma fraude trabalhista.

O terceiro elemento a ser analisado é a prestação de serviços de forma nãoeventual. Primeiramente, ressalta-se que não-eventual é um termo controvertido. Enfrentemos essa questão sob o prisma da interpretação pela negativa. Godinho ${ }^{51}$ caracteriza o trabalho eventual como aquele de natureza descontínua, "a não permanência em uma organização com ânimo definitivo", que não se fixa juridicamente a uma única tomadora de serviço, que tem curta duração, com a natureza do trabalho geralmente ligado a evento episódico (safra, plantio e etc.) e que tende a não corresponder "ao padrão dos fins normais do empreendimento".

Nesse sentido, consequentemente, o trabalho que não seja prestado com as características do eventual pode ser caracterizado, como não-eventual. Nesse ponto, podemos aproveitar um conceito usado por Amauri Mascaro Nascimento ${ }^{52}$ para conceituar a figura do empregado: o animus contrahendi, ou seja, a vontade de ser empregado. Se um trabalhador presta serviços, ainda que somente algumas vezes por semana, a um empregador, ele tem o referido animus e não se enquadra nas características do trabalhador 
eventual. Podemos, então, dizer que se caracterizou o elemento da não-eventualidade, necessário à relação de emprego.

O penúltimo elemento que iremos analisar é o da onerosidade. O salário é a forma pela qual o empregado recebe pelo valor do seu trabalho. Ressalta-se, todavia, que é evidente, conforme já fora analisado, que o valor pago ao empregado, como contraprestação à execução de seu trabalho, não corresponde ao valor efetivo gerado pelo trabalho humano prestado. A onerosidade, como bem assevera Godinho, deve "ser enfocada sob a ótica do prestador de serviços: apenas nessa perspectiva é que ela constitui elemento fático-jurídico da relação de emprego" ${ }^{33}$. O autor expõe as duas dimensões da onerosidade: a objetiva e a subjetiva.

No campo da objetividade, o efetivo pagamento - ainda que não totalmente em dinheiro, conforme prevê a CLT em seu artigo 458 - constitui o salário do empregado. Quanto à dimensão subjetiva, o elemento aqui tratado impõe-se ao animus do empregado de receber salário, ou seja, obter a contraprestação pela prestação de seus serviços. Dessa forma, afasta-se, por exemplo, a caracterização do vínculo empregatício entre um tomador de serviços e um trabalhador voluntário.

O salário do empregado representa os ganhos percebidos pelo seu trabalho em face de sua exploração por outrem. O empregador usa os serviços do empregado, em proveito próprio e, por isso, se obriga a garantir a existência de uma contraprestação que garanta um mínimo de dignidade ao indivíduo que dispõe de sua força de trabalho.

Pelos contornos eminentemente econômicos que a onerosidade impõe à relação de emprego, o ordenamento jurídico confere ao salário, por conta de seu valor social, uma série de garantias. Nesse sentido, Amauri Mascaro Nascimento ${ }^{54}$, elenca os principais princípios básicos de proteção jurídica do salário, quais sejam: a sua irredutibilidade, inalterabilidade prejudicial, impenhorabilidade e intangibilidade.

Percebe-se, novamente, a fundamental incidência do princípio da melhoria gradual e contínua das condições econômicas e sociais do trabalhador, dessa vez aplicado ao sistema de proteção do salário do empregado. 
Resta, nesse capítulo, falarmos da subordinação na relação de emprego. Como já fora dito anteriormente, dentre os elementos caracterizadores da relação de emprego, a subordinação é aquele que une todos os demais na construção doutrinária da relação de emprego. Afinal, o trabalhador não trabalharia para um mesmo empregador, com regularidade, sem se fazer substituir e recebendo salário, caso não estivesse subordinado a ele.

Ressalta-se, todavia, que subordinação não é, pura e simplesmente, cumprir ordens. Justamente pela sua difícil caracterização e pelo seu grau de importância para a aplicação do direito do trabalho, devemos dar especial atenção à subordinação, refazendo, o caminho que levou à caracterização contemporânea do seu conceito na relação de emprego.

A doutrina é pacífica ao entender que a subordinação que importa ao direito do trabalho é a subordinação jurídica, decorrente do contrato de trabalho. Nesse sentido, Délio Maranhão afirma que "a subordinação do empregado é jurídica, porque resulta de um contrato: nele encontra seu fundamento e seus limites" e quanto ao entendimento de que a subordinação não é o mero cumprimento de ordens, continua: “o empregado não é 'servo' e o empregador não é 'senhor"”, 55 .

Da mesma forma, Godinho afirma que a subordinação "consiste, assim, na situação jurídica derivada do contrato de trabalho, pela qual o empregado comprometer-se-ia a acolher o poder de direção empresarial no modo de realização de sua prestação de serviços." ${ }^{\circ 6}$.

Nesse sentido, o trabalhador pode ser considerado subordinado e parte integrante de uma relação jurídica de emprego ao estar totalmente integrado às condições de trabalho que lhe são dadas pela organização da produção, impostas pelo empregador.

\section{III.5 - A subordinação como elemento necessário à afirmação de direitos sociais nas relações de trabalho capitalistas}

Vimos como o trabalho é subordinado ao capital, bem como o papel que essa subordinação exerce no plano da gerência da força de trabalho. Além disso, encaramos também o viés jurídico de tal subordinação como elemento fundamental da relação de

55 SUSSEKIND, Arnaldo; MARANHÃO, Délio; VIANNA, Segadas; TEIXEIRA, Lima. Instituições de direito do trabalho. $22^{\mathrm{a}}$ ed. Vol. 1. São Paulo: LTr, 2005. p. 246

56 Op. cit. p. 302 
emprego. Vamos, agora, dissecar o conceito da subordinação jurídica, inserindo-a no plano social de sua configuração prática.

Otávio Pinto e Silva ${ }^{57}$, analisando a evolução do conceito de subordinação, identifica os critérios usados pela doutrina para conceituar esse elemento definidor da relação de emprego. Seriam eles: subordinação jurídica, dependência econômica, dependência técnica e dependência social. Para melhor compreendermos o conceito jurídico de subordinação, é importante atentarmos para cada uma destes sub-elementos que compõem o conceito acabado. Ainda que se tenha encarado a dependência do trabalhador face o empregador apenas sob o critério da subordinação jurídica, podemos dizer que os demais elementos da dependência são componentes da subordinação, à medida que na evolução histórica deixaram sua marca na definição do conceito. Assim, é de rigor analisá-los.

A dependência econômica é a posição do trabalhador, que depende do emprego que lhe é ofertado para sobreviver, perante o empregador. Délio Maranhão ${ }^{58}$, explica que tal critério nem sempre é válido, na medida em que pode existir dependência econômica entre pessoas jurídicas - como é o caso do grupo de empresas de que trata o artigo $2^{\circ}, \S 2^{\circ}$ da CLT - e nem por isso estará caracterizada a relação de emprego entre essas empresas,. Além disso, relata o autor, seria absurdo descaracterizar o vínculo empregatício de um trabalhador que consegue uma fonte de renda que o faça não depender mais exclusivamente do empregador para a sua subsistência, ou mesmo que seja independente em relação a esse, utilizando seu salário como fonte de renda complementar.

Tais ponderações estão corretas no âmbito específico proposto por Maranhão. É importante, todavia, que se faça uma reflexão sobre a real dimensão da dependência econômica do empregado perante o empregador. Dependência econômica não é, única e exclusivamente, a posição na qual fica alguém que precisa da remuneração paga por outrem para sobreviver. Está também, por exemplo, em condição de dependência econômica alguém que, em um processo de negociação, não tem poder de barganha suficiente para fazer jus a determinadas imposições.

57 SILVA, Otávio Pinto. Subordinação, Autonomia e Parassubordinação nas Relações de Trabalho. São Paulo: LTr, 2004.

58 Op. cit. p. $244-245$ 
Parece claro que um trabalhador fique em situação de dependência econômica em relação ao tomador de seus serviços quando fornece sua mão-de-obra. Isso porque este empregador poderá dispor da força de trabalho da forma que quiser esegundo seus interesses, realizando uma atividade econômica que muitas vezes o trabalhadorsequer sabe qual é. E se, por ora, isso não basta para a total redefinição do conceito de subordinação já demonstra um possível viés a ser adotado.

Outra faceta da análise subjetivista da expressão dependência se dá pela dependência técnica. Está em dependência técnica de alguém aquele que não possui os meios adequados para organizar sua prestação de serviços. Em outras palavras, aquele que está sob a direção técnica de outro, que lhe dita à forma como os serviços devem ser prestados. Vimos no tópico anterior que um dos princípios da gerência científica, tal qual a proposta por Taylor, é justamente manter o trabalhador nessa condição. Mais do que não ter condições de organizar sua prestação de serviços, simplesmente tal possibilidade lhe é negada pela gerência.

Outro elemento citado é o da dependência social, que seria a conjugação dos elementos jurídicos e econômicos da subordinação. Muitos problemas podem ser levantados em relação a esse critério de classificação da dependência. Devemos, então, refletir, sobre a posição do empregado, tendo em vista a figura do empregador, em uma estrutura de produção de uma dada empresa. A sujeição do trabalhador ao capitalista já foi muito abordada em nosso estudo. Ainda que não possamos falar em dependência social no sentido estritamente jurídico da relação de emprego, é certo que a posição socialmente inferior de um perante o outro perpassa toda a relação entre os dois.

Délio Maranhão explica de forma bem lúcida o raciocínio jurídico que levou à caracterização da subordinação do empregado perante o empregador. Explica o autor que:

\footnotetext{
“o empregador, que exerce um empreendimento econômico, reúne, em sua empresa, os diversos fatores de produção (...). Desses fatores, o principal é o trabalho. Assumindo o empregador, como proprietário da empresa, os riscos de empreendimento, claro está que lhe é de ser reconhecido o direito de dispor daqueles fatores, cuja reunião forma uma unidade técnica de produção. Ora, sendo o trabalho, ou melhor, a força de trabalho, indissoluvelmente ligada à sua fonte, que é a própria pessoa do trabalhador, daí decorre, logicamente, a situação
} 
subordinada que este terá de ficar relativamente a quem pode dispor de seu trabalho"s9.

É possível distinguir vários dos elementos subjetivos da dependência entre os elementos descritos pelo referido autor como justificantes da subordinação do empregado perante o empregador. Quando se diz que o empregador reúne todos os fatores de produção, essa expressão carrega um enorme caráter econômico que, ainda que não tenha o condão de produzir dependência, também não pode ser afastado da análise da relação de emprego. Além disso, a caracterização do empregador como alguém que dispõe da força de trabalho da melhor forma possível para organizar uma unidade e produção também guarda estreita relação com a subjetividade da expressão "dependência técnica”. E, finalmente, na afirmação de que o empregador pode dispor da força de trabalho do empregado - que obviamente está indissoluvelmente ligada à pessoa do trabalhador - temos um profundo elemento social. Não se pretende, enfim, justificar única e exclusivamente o uso dos conceitos de dependência no bojo da caracterização da subordinação, nem tampouco afirmar, de pronto, a sua imprescindibilidade quando da conceituação do fenômeno jurídico que é a subordinação na relação de emprego.

Percebe-se, assim, que a subordinação jurídica é um elemento que - além de ser essencial e multifacetado - transcende as discussões doutrinárias sobre sua caracterização, podendo assumir as mais diversas formas de dependência e sujeição do empregado ao empregador, sendo fundamental para o direito do trabalho como elemento definidor da relação de emprego.

Sendo o empregado um trabalhador subordinado, ele estará sujeito ao poder de direção do empregador. Dessa forma, com a existência de vínculo empregatício inevitavelmente irá existir o poder de direção subordinando a prestação de serviços do empregado.

Assim, temos que o empregador organiza o trabalho do empregado; fiscaliza-o para garantir que está sendo cumprido a contento; e, em caso de infrações mais graves, pode puni-lo com sanções disciplinares. É evidente, dessa forma, que - pelo menos no âmbito privado da empresa - a subordinação do empregado ultrapassa os limites do fenômeno

59 Idem. p. 245 
jurídico.

Godinho utiliza uma definição de subordinação que, além de muito correta, pode nos auxiliar de maneira decisiva na constatação do que propomos com este tópico. Para ele:

"a subordinação corresponde ao pólo antitético e combinado do poder de direção existente no contexto da relação de emprego. Consiste, assim, na situação jurídica derivada do contrato de trabalho, pela qual o empregado comprometerse-ia a acolher o poder de direção empresarial no modo de realização de sua prestação de serviços" ${ }^{90}$

Assim, havendo poder de direção e atuação da gerência científica na organização do trabalho e da produção, haverá relação de emprego trabalho subordinado. E havendo relação de emprego e trabalho subordinado, é necessária a intervenção do Estado, através da tutela estabelecida pelo direito do trabalho.

60 Op. cit. p. 302 


\section{IV - A INTENSIFICAÇÃO DA EXPLORAÇÃO}

Pretende-se, no presente capítulo analisar as maneiras através das quais as novas formas de gerência e organização do trabalho interferem na forma de exploração do trabalho. Afirmamos anteriormente a inerência da exploração do trabalho para o capitalismo, e agora aprofundaremos nosso estudo com a caracterização da exploração no contexto atual da forma de organização do trabalho.

Precarização, "trabalho flexível”, e subcontratação de trabalhadores. Ao enfrentar esses dilemas do direito do trabalho, devemos sempre buscar a solução que mais se aproxime da efetivação máxima dos direitos sociais. Neste contexto, a conceituação do elemento subordinação é de fundamental importância. Como elemento definidor da relação de emprego - e, consequentemente, da hipótese de incidência clássica do direito do trabalho, com toda a criação de direitos subjetivos e responsabilidades que ele enseja - é sobre a subordinação que recaem todas as espécie de mutações e deformidades a fim de descaracterizar o trabalho subordinado típico.

Das diversas formas de descaracterização do empregado típico, ganha mais espaço a que elimina a subordinação. Assim é que é cediço, tanto na doutrina quanto na jurisprudência, que qualquer fraude contra os direitos dos trabalhadores não se sustenta caso reste caracterizada a presença da subordinação. Percebe-se, assim, que não havendo subordinação, praticamente não há direito do trabalho. A questão, todavia, é mais complexa. Isso porque, conforme já fora dito, o trabalho subordinado se justifica na medida em que submete a prestação de serviços ao poder de organização, físcalização, controle, enfim, ao poder de direção do empregador, o modo como ele dirige os fatores de produção que tem à sua disposição, no sentido de melhor realizar sua atividade econômica, em proveito de si ou de sua empresa. Acabar com o trabalho subordinado praticamente implica acabar com o poder que o dono dos meios de produção tem sobre tais meios, ou sobre o principal fator que transforma esses meios em produção, qual seja, o trabalho humano.

Percebe-se, portanto, que ainda que a forma de organização do trabalho e da produção tenha mudado, não dá para "apagar" todo e qualquer traço da subordinação nas 
relações de trabalho típicas. Assim, parece-nos praticamente inata às relações de compra e venda de mão de obra, das relações de exploração da força de trabalho humana, a existência de dependência ou subordinação do empregado para com o empregador.

\section{IV.1 - Terceirização, subcontratação e precarização do trabalho}

A nova realidade imposta à forma de organização do trabalho, pelas mudanças ocorridas na gerência da produção, cria uma situação em que as teorias em torno da necessidade de revisão do conceito de subordinação jurídica - como elemento definidor da relação de emprego e base do direito do trabalho - ganham cada vez mais espaço e repercussão. ${ }^{61}$

Conforme se verá adiante, a terceirização é fenômeno que possui ampla repercussão e, hodiernamente, é adotada por praticamente todas as empresas Ela pode ser definida por duas modalidades de interposição de mão-de-obra: A primeira delas consiste em colocar trabalhadores dentro da própria empresa, realizando atividades não essenciais a consecução de sua finalidade produtiva - as chamadas atividades-meio - em contraposição às atividades-fim. Já a segunda forma, identificada como subcontratação, as empresas contratam os serviços de outras empresas para a realização - de maneira externa à planta industrial - de serviços de produção de produtos que serão apenas "juntados" pela empresa contratante para a produção final do produto que é o objeto de sua fabricação. Nessa modalidade, o já inconsistente conceito de "atividade-fim" e "atividade-meio" perde ainda mais sua significação, ficando mais difícil de identificar.

Ressalta-se que as empresas se utilizam cada vez mais dos serviços de outras empresas que possuem uma alta especialização em determinados setores e que fornecem mão de obra especializada a baixo custo. A subcontratação, como forma de terceirização, fundamenta-se, basicamente, nesses preceitos. É interessante notar que é consenso no meio jurídico que a intermediação de mão de obra é vedada em nosso ordenamento. Falta, todavia, uma discussão mais profunda sobre o que realmente é terceirização, bem como sobre o que é intermediação de mão de obra e quais são, realmente, as diferenças entre essas duas formas de contratação de trabalhadores.

61 Sobre o assunto podemos citar: Walküre Lopes Ribeiro da Silva, "Revisão dogmática da subordinação diante das transformações do mercado de trabalho" e Pedro Proscurcin, "O fim da subordinação clássica no direito do trabalho". 
Em artigo sobre a terceirização na região metropolitana de Salvador, Graça Druck e Tânia Franco ${ }^{62}$ invocam uma pesquisa realizada pelo jornal Gazeta Mercantil, em 2000, segundo a qual de cem empresas pesquisadas na Bahia, 100\% dessas do setor industrial declaravam contratar trabalhadores terceirizados, bem como $100 \%$ do setor de finanças, $94 \%$ do setor de serviços, $83 \%$ do agrobussines e $44 \%$ do comércio.

Percebe-se que a terceirização está presente, em alguns casos, em literalmente $100 \%$ das empresas. Logo, esse é um fenômeno com considerável importância no processo produtivo dessas empresas e não pode ser tratado como algo que não guarda relação com o processo de produção, restringindo-se a atividades secundárias.

Podemos citar um exemplo disso: a súmula 331 do TST dispõe que a intermediação de mão de obra é ilegal, salvo em alguns casos, como, por exemplo, o trabalho temporário, os serviços de vigilância, os serviços de limpeza e os serviços ligados às atividades meio do tomador de serviços. Qual foi o critério utilizado para definir essas exclusões? Caso tenha sido a legislação específica e determinada, então os serviços de limpeza não poderiam figurar nessa lista. Além disso, a questão em torno da atividade meio do tomador também é um tanto quanto nebulosa, cabendo um questionamento: podemos considerar como atividade meio de uma instituição financeira - que movimenta fisicamente valores altíssimos em dinheiro - a guarda e conservação desses valores? A legislação e a jurisprudência entendem que sim, entretanto nos parece um contra senso entender assim a atividade de alguém que faz a segurança de dinheiro, em uma empresa que tem como uma das atividades-fim guardar dinheiro, só para citarmos um exemplo. Mesmo a limpeza como atividade-meio é profundamente questionável, como veremos adiante.

No Congresso nacional, tramitam hoje diversos projetos de lei (PLs) que tratam do assunto. Alguns apenas reproduzem o texto da súmula do TST referida, outros buscam aumentar a proteção dessa modalidade de contratação, que tem trabalhadores tão precarizados. Nenhum PL, porém, entra no cerne da questão da terceirização. Ainda que se argumente que não há como lutar contra uma tendência real da organização do trabalho, concluindo, portanto, que a terceirização não pode ser abolida, tal argumento carece de

62 DRUCK. Graça e FRANCO, Tânia. Terceirização e precarização: o binômio anti-social em industrias in: DRUCK. Graça e FRANCO, Tânia (org.). A perda da razão social do trabalho: terceirização e precarização. São Paulo: Boitempo, 2007. p. 97-118 
fundamentação, na medida em que algumas questões ficam em aberto: e a representação sindical dos terceirizados? Porque um empregado que trabalha ao lado de outro, por vezes exercendo a mesma função, pode ter direitos previstos em acordos e convenções coletivas que o outro não possui? E a questão da responsabilidade do tomador de serviços, não só pelo inadimplemento das verbas rescisórias, mas pela garantia de cumprimento das normas de tutela trabalhista durante a vigência do contrato de trabalho?

Além destas, muitas outras questões ficam sem respostas claras e conclusivas. A terceirização no Brasil, dada a nossa cultura de descumprimento da legislação trabalhista, é um verdadeiro problema social. Agora, o que falar de um descumprimento de uma legislação trabalhista que não existe? Seria razoável milhares e milhares de trabalhadores ficarem sem qualquer proteção por causa de uma necessidade gerencial da "nova empresa?"

No artigo referido anteriormente, as pesquisadoras alertam que "o que se constata é a terceirização indiscriminada, sem qualquer preocupação em diferenciar 'atividade-fim' e 'atividade-meio" "63. Dessa forma, percebe-se que as tentativas de vedação da legislação e da jurisprudência a esse tipo de contratação não têm surtido o efeito pretendido.

Uma das razões pelas quais isso acontece é a capacidade de mutações que o capital consegue imprimir à organização do trabalho, no sentido de melhor adequá-la aos seus interesses de reprodução. Se um instrumento de subcontratação é liberado, permitindo-se que que os empregadores se utilizem dele, a probabilidade disso representar mais precarização das condições de trabalho é altíssima.

As referidas pesquisadoras constatam que os efeitos da terceirização sobre os empregados contratados - que aparentemente seriam imunes à subcontratação - são enormes, na medida em que esses empregados acabam sendo pressionados diante da possibilidade de terem seus empregos substituídos por empresas terceirizadas que representariam menos custos ao empregador ${ }^{64}$. Cria-se uma condição de medo e stress na classe trabalhadora, gerando efeitos nefastos para a dignidade e valorização do trabalhador. Ressalta-se que direito não pode coadunar com esse tipo de prática empresarial, sob pena,

63 Idem p. 104

64 Ibidem. p. 106 
não só de se esquecer a grande função do direito do trabalho, mas também das regras trabalhistas apenas servirem aos interesses de alguns em detrimento de muitos.

Rodrigo de Lacerda Carelli, escrevendo sobre a legislação do trabalho temporário no Brasil, ${ }^{65}$ diz que essa legislação "em nada tem a acrescentar e é injustificável perante a legislação brasileira". O autor explica que essas leis foram importadas da Europa Ocidental, onde, em regra, vige a vedação da dispensa arbitrária - imotivada. Por isso as empresas que precisavam contratar empregados, por exemplo, por conta de um período de demanda elevada, se viam sem saída, na medida em que uma vez contratado, o empregado não poderia ser dispensado sem justa causa.

No Brasil, não é isso que acontece. Com a criação do FGTS e o fim da estabilidade, a legislação do trabalho temporário serve apenas como mais um fator de precarização do trabalho. Percebe-se, assim, que justamente a legislação trabalhista, que deveria proteger o trabalhador hipossuficiente, é que facilita a sua exploração desenfreada.

Ainda que se trate de terceirização propriamente dita, devemos estar atentos à contratação de serviços especializados realizados por empresas autônomas, tendo em vista a tendência de maquiar as atividades-fim, como se de meio fossem. Além disso, a terceirização é um fenômeno muito prejudicial para a afirmação do valor social do trabalho, bem como para efetivar sua dignidade. Vide, por exemplo, uma empresa metalúrgica que terceirize seus serviços de limpeza: esses trabalhadores não serão representados pelo sindicato da categoria, nem terão os mesmos benefícios dos acordos e convenções coletivas firmados com o empregador. Isso porque - apesar de trabalharem no mesmo espaço físico, colaborando para a consecução da mesma atividade econômica - os trabalhadores terceirizados possuem empregadores diferentes dos empregados da empresa, pertencendo até mesmo à uma categoria profissional distinta.

É claro que a responsabilidade do tomador de serviços em relação ao pagamento de verbas trabalhistas é subsidiária à da empresa de serviços contratada. A discussão, porém, não pode ficar em torno apenas do pagamento de verbas rescisórias, na medida em que a afirmação e valorização do trabalhador não passa apenas pelo correto pagamento de tais

65 CARELLI, Rodrigo de Lacerda. Terceirização e direitos trabalhistas no Brasil in DRUCK...op. cit. p. 5968 
verbas, mas sim pela sua importância enquanto fator de produção, que gera valor e colabora para a consecução do fim social da empresa. Ou por acaso, o trabalhador que limpa o ambiente de trabalho não está colaborando para a atividade fim da empresa?

Muito elucidativo dessa diferenciação é o lamentável exemplo de nossa Universidade, ocorrido em abril de 2011. Por conta de atrasos no pagamento de salários e das péssimas condições de trabalho, trabalhadores de uma empresa que prestava serviços de limpeza para a USP paralisaram seus serviços. Não tardou muito para que, diante da total falta de condições de higiene, a diretoria da Faculdade de Filosofia, Letras e Ciências Humanas suspendesse as atividades da unidade. ${ }^{66}$ Fica a pergunta: será mesmo possível considerar atividade-meio um serviço que impede o próprio funcionamento de um local de trabalho? Entendemos que não, contudo, precisa ser ressaltado que - para além de discussões caso a caso do que é "fim" e do que é "meio" - essa própria discussão é completamente datada, na medida em que tais conceitos foram criados apenas para legitimar a terceirização. Assim, antes da popularização dessa forma de contratação de trabalhadores, era totalmente irrelevante classificar qual era a atividade-fim ou atividademeio de uma empresa.

Em tempos de especialização flexível, terceirização, e subcontratação, o direito do trabalho também deve se especializar, buscando elementos que possam tutelar as novas relações sociais de trabalho que estão surgindo. Nas palavras do professor Márcio Túlio Viana "também o direito do trabalho terá de ser flexível, mas não no sentido de abrir espaço ao mais forte, e sim no de persegui-lo em suas mutações" ${ }^{67}$.

Perseguir o mais forte em suas mutações não é tarefa fácil. Isso porque essa "perseguição" implica criar normas e regras jurídicas que estejam constantemente atualizadas perante o mundo do ser, na medida em que as transformações econômicas - e, por consequência, da organização do trabalho - tendem a ocorrer rapidamente.

Percebe-se, assim, que a clássica visão doutrinária da subordinação entendida apenas no seu sentido estritamente jurídico, decorrente de um contrato, não oferece o

66 http://www.estadao.com.br/noticias/vidae,fflch-suspende-aulas-por-falta-de-limpeza-na-usp,704884,0.htm Acesso em 27/10/11

67 VIANA, Marcio Túlio, Terceirização e sindicato: um enfoque para além do jurídico in Revista LTr: legislação do trabalho. São Paulo, ano 67, nº 7, pp. 789-790. jul. 2003. 
mesmo grau de proteção e tutela das relações de trabalho como outrora. Dessa maneira, são buscadas novas formas de tutela trabalhista.

\section{IV.2 - Trabalho flexível}

A expressão "trabalho flexível” se difundiu na última década nos meios acadêmicos de economia e sociologia do trabalho para designar um novo modelo de trabalho implantado a partir do sistema toyotista de gerência da empresa em contraposição ao modelo fordista. Muitos teóricos que usam essa expressão afirmam que o trabalhador inserido nesse novo modelo passa a exercer uma atividade flexível, que lhe exige novas e múltiplas habilidades.

Esse discurso, todavia, serve muitas vezes para mascarar uma situação de super exploração do trabalho, transferindo ao trabalhador responsabilidades sobre o sucesso da atividade econômica, travestidas de liberdade e parceria na organização da empresa. Ressalta-se que a origem da teoria do trabalho flexível está ligada ao modo de acumulação que substituiu o fordismo, após a crise da década de 70. Além disso, o modelo toyota é também chamado de acumulação flexível e daí surgem as designações que incorporam essa flexibilidade também ao trabalho. O trabalho, entretanto, continua sendo o mesmo, sendo certo que o que mudou foi a forma da gerência científica de empresa. Ainda que questionemos essa mudança como algo estrutural, examinemos melhor o sistema toyotista de acumulação.

Após o fim da segunda guerra mundial, o capitalismo entrou em uma fase de acumulação eufórica. O crescimento econômico, aliado a políticas de estado keynesianas nos países centrais, levou a uma lógica de produção e acumulação capitalista que ficou conhecida como "anos gloriosos" do capitalismo ${ }^{68}$.

Esse período se caracterizou pela produção em massa de bens de consumo, bem como por políticas sociais de bem-estar que retroalimentaram a lógica de acumulação, gerando estabilidade e confiança nos mercados globais. Essa lógica de produção, aliada a tais políticas, colocou o mundo em um espiral de crescimento, que se pensava ser muito mais duradoura do que realmente foi.

68 PRADO, Antonio. A controvérsia da crise do fordismo e a transição pós-fordista: algumas reflexões sobre o caso brasileiro in: Emprego e desenvolvimento tecnológico: processos de integração regional. São Paulo: DIEESE, 1999. p. 16 
A crise de produção da década de 70 , aliada às desestabilizações econômicas daquele período, afetou profundamente a estrutura do padrão de acumulação, levando os fatores de produção a se reorganizarem a fim de fazerem frente às novas demandas dos mercados em crise.

O modelo fordista de produção não conseguia mais atender a essas novas demandas, e novos modelos começaram a ser procurados. Uma das possíveis respostas veio do Oriente, mais precisamente de uma fábrica da montadora de veículos Toyota: um sistema produtivo baseado em uma produção mais flexível, sem a rigidez marcante da produção em massa desenvolvida por Henry Ford. Justamente o que era necessário para enfrentar a crise de produção e consumo das décadas de 70 e 80.

Ricardo Antunes, em seu livro "Os Sentidos do Trabalho", faz uma abordagem crítica da nova forma de organização dos fatores de produção, apontando as principais características do modelo Toyota de produção.

O autor afirma queo toyotismo é marcado por uma forma de produção voltada à demanda, abandonando o antigo modelo de produção de bens massificados. Dessa forma, seria possível adotar um processo produtivo flexível, no qual o princípio do just in time proporcionaria o melhor aproveitamento possível do tempo, do trabalho e da produção. Como consequência dessa mudança na estruturação do modelo de produção, as empresas que adotam o toyotismo utilizam o chamado sistema kanban, ou seja, o estoque voltado única e exclusivamente para a produção, que por sua vez é mais flexível e voltada para a demanda, possibilitando a redução do material de reposição ao mínimo possível. Noutro sentido, grande parte da produção - 75\% segundo os apontamentos de Antunes - é transferida para empresas terceirizadas, com a consequente expansão desse modelo produtivo para uma rede de outras empresas que participam do processo de produção de forma indireta e, de certa forma, "autônoma". 69

Além do grande impacto que a terceirização traz para as relações de trabalho, o modelo toyota também encerra mudanças na forma de organização interna dos trabalhadores. O trabalho operário é multifacetado, com uma variedade enorme de funções, e a formação de equipes de trabalho torna-se fundamental para que a empresa funcione

69 ANTUNES, Ricardo. Os Sentidos do Trabalho. São Paulo: Boitempo, 1999. p. 52-53 
dentro dessa lógica flexível. Nesse aspecto, na tentativa de abarcar o trabalhador na "gerência" da empresa, são criados os chamados CCQ (Círculos de controle de qualidade):

\begin{abstract}
"grupos de trabalho que são instigados pelo capital a discutir seu trabalho e desempenho, com vistas a melhorar a produtividade das empresas, convertendose num importante instrumento para o capital apropriar-se do savoir fare intelectual e cognitivo do trabalho, que o fordismo desprezava" ${ }^{70}$.
\end{abstract}

Pois bem. A introdução desses elementos na nova forma de organização da produção nas fábricas caracteriza, grosso modo, o toyotismo. Essa forma de organização produtiva, todavia, não é uniforme nem tampouco - como, por sua própria estrutura ideológica, não poderia de ser - rígida. O modelo toyota, reação à crise do capitalismo da década de 70 , ensejou mudanças na forma de produção em quase todos os países, que precisaram se adaptar à nova realidade dos mercados saturados. Essa adaptação e transposição do modelo toyotista para as mais diferentes partes do globo acabou por descaracterizá-lo, porém iniciou uma nova ordem de acumulação do capital, que podemos chamar de acumulação flexível. ${ }^{71}$

A adoção do toyotismo pelas empresas na busca de respostas à crise estrutural do modelo de acumulação resultou em uma mistura de sistemas produtivos, com a característica de reprodução da lógica capitalista e exploração do trabalho humano. Nesse sentido Jorge Luiz Souto Maior afirma que "pode-se dizer, não existe, propriamente um modelo toyotista, mas vários modelos distintos de produção, que têm em comum a aumento da exploração do trabalho pelo capital". ${ }^{72}$ Nessa mesma linha Ricardo Antunes afirma que "a ocidentalização do toyotismo (eliminando os traços singulares da história, cultura, tradições que caracterizam o Oriente japonês) conformaria em verdade uma decisiva aquisição do capital contra o trabalho"73.

A intensificação da exploração do trabalho pelo capital é muito bem demonstrada na supracitada obra de Ricardo Antunes, "Adeus ao Trabalho". O autor afirma que a

70 Idem. p. 55

71 ANTUNES, Ricardo. Adeus ao Trabalho?: ensaio sobre as metamorfoses e a centralidade do mundo do trabalho. 12a ed. São Paulo: Cortez ; Campinas: Editora da Universidade Estadual de Campinas, 2007.

72 SOUTO MAIOR, Jorge Luiz. Relação de Emprego \& Direito do Trabalho: no contexto da ampliação da competência da justiça do trabalho. São Paulo: LTr, 2007. p. 42

73 Op. cit. p. 41 
acumulação flexível transforma o operário máquina, típico do fordismo, em um operário que é várias maquinas, aumentando a produção sem aumentar o número de empregados. Nesse sentido, uma conta rápida e fácil pode ser feita: se o novo modelo de acumulação aumenta a produção mantendo o mesmo número de empregados trabalhando, então está criando mais valor com uma mesma quantidade de trabalho, sem o correspondente aumento de salários, ou então está se extraindo mais trabalho de uma mesma quantidade de pessoas. Não é difícil, portanto, constatar o aumento da exploração do trabalho pelo capital.

As mudanças econômicas foram acompanhadas de mudanças na agenda política dos países, com a saída de cena do ideário keynesiano para dar lugar às políticas neoliberais.

Marilena Chauí, ao analisar a teoria econômico-política do neoliberalismo, aponta algumas características do novo modelo de Estado que surge com a política neoliberal. Contrapondo-se ao Estado de bem-estar social, os neoliberais identificaram o problema criado por esse Estado, pois "para garantir simultaneamente a acumulação e reprodução do capital e a da força de trabalho, o Estado do Bem-Estar Social endividou-se e entrou num processo de dívida pública conhecido como déficit fiscal ou "crise fiscal do Estado",74.

Diante desse quadro, as teorias neoliberais de "enxugamento" do Estado encontraram um terreno fértil para colocar seu ideário em prática. Assim é que o Estado que vemos hoje é muito menos intervencionista e mais preocupado em proporcionar liquidez ao mercado, deixando-o agir aos seus próprios interesses, sem nenhuma espécie de regulação. E o resultado disso é nefasto:

\footnotetext{
“agora o capitalismo dispensa e rejeita a presença estatal não só no mercado mas também nas políticas sociais, de sorte que a privatização tanto de empresas quanto de serviços públicos também se tornou estrutural. Disso resulta que a idéia de direitos sociais como pressuposto e garantia dos direitos civis ou políticos tende a desaparecer, pois o que era um direito converte-se num serviço privado regulado pelo mercado e, portanto, torna-se uma mercadoria apenas aos que têm poder aquisitivo para adquiri-la" 75
}

74 CHAUÍ, Marilena. Convite à filosofia. 13ª ed. $3^{\mathrm{a}}$ reimpressão. São Paulo: Ática, 2005. p. 401

75 Idem. P. 403 
E é claro que o Direito do Trabalho, direito social que é, não está imune a esse processo de deterioração dos direitos sociais, tornando-se também alvo das críticas desse novo modelo de Estado. Nesse sentido apontam Marcus Orione e Jorge Souto Maior:

\footnotetext{
"hoje em dia está, por exemplo, se dando muito respaldo à teoria neoliberal de que se o emprego acabou, o Direito do Trabalho deve se transformar em direito ao trabalho, não se importando tanto com a integralidade da proteção historicamente conquistada: melhor algum direito que nenhum"76
}

Pois bem. Vimos como se caracteriza o chamado toyotismo; analisamos suas implicações para a classe trabalhadora; e, por fim, observamos como ele influenciou a agenda politica dos países nas últimas décadas. Concluímos, dessa forma, que não foi o trabalho que se tornou flexível, mas sim sua forma de organização. Assim é que a exploração do trabalho não é nem um pouco flexível, e a adoção de politicas neoliberais pelos Estados em nada contribuiu para que esse cenário fosse mitigado em favor da classe trabalhadora.

Em assim sendo, nosso estudo reivindica proteção ao trabalhador, buscando melhorar suas condições de vida. Ressalta-se, entretanto, que essa proteção não se dá apenas com mais direito do trabalho. São também necessárias mais políticas de previdência e assistência social; saúde; educação; cultura; enfim, que o Estado não seja mais um instrumento para o sucateamento de serviços públicos e a opressão de classe.

No tópico a seguir iremos analisar se realmente o toyotismo é uma contraposição ao fordismo, no sentido da exploração do trabalho.

\section{IV.3 - A contraposição Taylor X Ohno}

Traçamos anteriormente um panorama do sistema taylorista de gerência científica da produção. Além disso, afirmamos, em linhas gerais, como se caracteriza o chamado modelo toyotista de organização do trabalho. Pretendemos, agora, fazer a inter-relação entre esses dois modelos, a fim de chegarmos ao ponto de investigação científica proposta nesse tópico: se há, de fato, uma diferença estrutural que oponha os modelos acima referidos de organização do trabalho e da produção.

76 CORREIA, Marcus Orione Gonçalves (org.). Curso de Direito do Trabalho. Volume 1. São Paulo: LTr, 2007. p. 37 
Inicialmente cumpre estabelecermos a exata relação entre fordismo e taylorismo. Ainda que na literatura especializada ambos venham citados juntos, como adjetivação de um ou de outro, é certo que foram pensados por pessoas diferentes, em momentos - ainda que muito próximos - distintos.

Conforme já afirmamos anteriormente, Taylor pensou sua gerência científica para ser aplicada indiscriminadamente a todos os tipos de trabalho. Henry Ford, por sua vez, formulou seu modelo inicialmente para a produção de veículos em série, com o objetivo de estabelecer um novo paradigma na produção de automóveis, o que o ajudou a popularizar o carro e tornar tão célebre sua indústria e seu método de produção.

Geraldo Augusto Pinto afirma: “Apesar de não ter citado Taylor, pelo menos em seu texto mais popular, intitulado Minha vida e minha obra, Ford não deve tê-lo ignorado, como apontam algumas de suas ideias aí dispostas, ora refutando os ideais tayloristas, ora exaltando-os, indiretamente". ${ }^{77}$ A observação dos métodos aplicados por Ford não deixam dúvidas quanto ao fato de que seu modelo de produção sofreu clara influência de Taylor, até porque, à época que Ford iniciou seus experimentos, o taylorismo era o que havia de mais avançado em matéria de gerência científica do trabalho

Especificamente sobre a diferença entre Taylor e Ford, o autor continua:

"Se a divisão de atividades entre vários trabalhadores, a elas limitados dentro de
funções específicas, já estava bastante avançada na indústria com a expansão do
sistema taylorista, a novidade introduzida por Ford, com a linha de produção em
série, foi a colocação do objeto de trabalho num mecanismo automático que
percorresse todas as fases produtivas, sucessivamente, desde a primeira
transformação da matéria-prima bruta até o estágio final (como o acabamento do
produto, por exemplo). Ao longo dessa linha, as diversas atividades de trabalho
aplicadas à transformação das matérias-primas ou insumos, foram distribuídas
entre vários operários fixos em seus postos, após terem sido suas intervenções
sub-divididas em tarefas cujo grau de complexidade foi elevado ao extremo da
simplicidade" 78

Porém, do ponto de vista do fordismo, mesmo essa diferença não é tão original .

77 PINTO, Geraldo Augusto. A organização do trabalho no século 20: taylorismo, fordismo e toyotismo. São Paulo: Expressão Popular, 2007. p. 41.

78 Idem. p. 42. 
Nesse sentido o autor acentua:

\begin{abstract}
"A divisão taylorista havia possibilitado que se distribuísse os trabalhadores e suas ferramentas efetivamente ao longo de uma linha, ao padronizar o trabalho em atividades cujas operações eram uniformizadas. Pode-se dizer, nesse sentido, que o sistema taylorista foi incorporado e desenvolvido pelos dispositivos organizacionais e tecnológicos fordistas, na medida em que, no lugar dos homens responsáveis pelo deslocamento dos materiais e objetos de trabalho, máquinas automáticas passaram a se encarregar por tal, suprindo o trabalho humano numa produção cuja cadência contínua impunha uma concentração dos movimentos dos trabalhadores somente dentro do raio de ação que efetivamente transformava as matérias-primas em produtos acabados" $" 79$
\end{abstract}

Nesse sentido, podemos auferir que o fordismo é uma espécie de taylorismo mecanizado, o que corrobora a opção pela nomenclatura fordismo/taylorismo para designar um determinado modelo de gerência e organização do trabalho e da produção. Uma implicação do taylorismo mecanizado é a criação de homens-máquina, trabalhadores que nada mais são do que uma peça em uma grande engrenagem de produção, tal qual celebrizado pelo grande Chaplin em seu filme "Tempos Modernos".

A criação da figura do operário massa - que, de acordo com os desejos do seu empregador, pode se encaixar em qualquer área da produção, bem como ser remanejado para outras funções - é outra característica do fordismo/taylorismo. E esse modelo de organização do trabalho possui inúmeras implicações para a classe trabalhadora, todas elas passando, necessariamente, pelo incremento da alienação do trabalho e super exploração do trabalhador.

Pois bem. Traçado esse panorama e estabelecida a relação entre fordismo e taylorismo, podemos partir para a análise do modelo toyota de produção e sua relação com o modelo anterior. Ressalta-se que já tratamos, em momento precedente de nosso estudo, da crise do modelo fordista de produção até transição para o modelo toyotista, identificando, de maneira geral, os elementos que levaram à crise do fordismo e geraram a necessidade de um novo modelo de organização do trabalho.

Geraldo Augusto Pinto identifica as principais necessidades desse novo modelo 79 Idem. pp. 43-44. 
nascente:

“1. alta flexibilidade da produção, ou capacidade de produzir diferentes modelos de produtos num curto período de tempo, mantendo-se ou não a larga escala; 2. altos índices de qualidade nos produtos, o que reduziria inclusive custos de produção, em vista do baixo volume de retrabalho; 3. baixos preços finais, o que poderia ser obtido não apenas pela redução do re-trabalho e pela flexibilidade produtiva, mas através da manutenção de uma 'fábrica mínima', operando sempre com baixíssima capacidade ociosa, tanto em termos de equipamentos, quanto estoques e de efetivo de trabalhadores;

4. entrega rápida e precisa, com os pedidos sendo entregues no momento exato estipulado pelo cliente, na quantidade exata e com um controle de qualidade que lhe garantisse pronta utilização na maioria dos casos" ${ }^{\prime 0}$

Basicamente essas necessidades imprimiram o modelo toyota de produção: just in time; produção sem estoques, através do sistema kanban; Círculos de Controle de Qualidade (CCQ); fábrica enxuta; flexibilidade na produção; em suma, as diretrizes para o que posteriormente foi identificado dentro de uma lógica maior de acumulação flexível, conforme já fora apontado anteriormente.

Contudo, todas essas mudanças na forma de produzir não alteraram um dos postulados básicos do capitalismo: a exploração do trabalho. Ao contrário, aprofundaramno. Ainda que identifiquemos mudanças substanciais na forma de produção de mercadorias - e aqui podemos identificar uma contraposição entre o fordismo/taylorismo e toyotismo é certo que essas mudanças vieram no interesse do capital. Suas implicações sobre a classe trabalhadora nunca foram consentidas ou discutidas com os trabalhadores, mas sim impostas de cima para baixo, sempre objetivando o incremento da produção e o aumento dos lucros em detrimento das melhores condições de vida da classe que vive do trabalho.

Mesmo os consensos e as pretensas melhorias nas condições de trabalho foram forjadas. Patrícia Tuma Martins Bertolin, analisando a transformação na forma de organização da produção, traça o seguinte cenário:

\footnotetext{
“o panorama instaurado por essa Revolução da Tecnologia é mais ou menos o seguinte: salários achatados, ritmo frenético no ambiente de trabalho, rápido
}

80 Idem. p. 51. 
crescimento do trabalho contingencial de meio período, desemprego tecnológico, aumento da disparidade de renda entre ricos e pobres e dramático encolhimento da classe média; tudo isso impondo um stress sem precedentes sobre a força de trabalho." ${ }^{\prime 1}$

Augusto Pinto identifica o modelo toyotista como o modelo da "gerência por estresse", no qual são estabelecidas metas para grupos de trabalhadores que tem no cumprimento dessas metas a responsabilidade por incremento de salários e, no limite, até mesmo por seus empregos. A criação de equipes de trabalho, através dos CCQs, cria uma falsa sensação de desalienação do trabalhador. Isso porque se o trabalhador se torna polivalente e conhece o funcionamento de sua equipe e das demais, parece que foi superado o paradigma alienante da esteira de produção fordista. Ocorre que essa sensação é ilusória e passageira, na medida em que o estresse gerado no trabalhador não supera o estranhamento do trabalho, até porque o processo produtivo é cada vez mais complexo e sequer se finaliza dentro de uma mesma indústria.

Percebe-se, assim, que esses mecanismos apenas transferem de maneira perversa os riscos da atividade econômica - inerente a atividade do empresário - ao trabalhador. Opera-se, assim, uma inversão inadmissível de condições, na medida em que o trabalhador, por todos os motivos já aqui enunciados, já está em situação de inferioridade perante seu patrão, não sendo correto que lhe seja impingida ainda mais essa responsabilidade. O mesmo autor já citado, em suas conclusões apresenta o seguinte:

“A evolução dessas técnicas de organização do trabalho ao longo desse período (séc. XX) é apenas uma dentre as muitas manifestações das lutas sociais travadas entre aqueles que dependem da venda de sua força de trabalho para sobreviver e aqueles que a compram no objetivo de acumular meios de produção e capital. Nesse sentido, deve-se ver a crise do taylorismo/fordismo frente ao avanço das organizações flexíveis, como o toyotismo, como um processo gestado dentro de uma conjuntura mais ampla, da qual faz parte a introdução das políticas neoliberais na atuação estatal, cujo principal atributo tem sido a renúncia a compensações sociais e à coletivização de direitos à totalidade da classe trabalhadora, nos contratos firmados com o empresariado" $" 82$

81 BERTOLIN, Patrícia Tuma Martins. A economia globalizada e seus efeitos sobre o Trabalho in: ARIENTE, Eduardo Altomare (coor.). Fronteiras do Direito Contemporâneo. São Paulo: Casa Vida. Diretório Acadêmico João Mendes Jr. p. 57-73, 2002.

82 Op. cit. pp. 99-100 
Podemos, assim, concluir que as mudanças na forma de organização do trabalho ao longo do século XX foram gestadas no seio do capital, sendo certo que as diferenças entre os modelos de produção podem ser consideradas pontuais, na medida em que possuem um objetivo maior, que é manter a acumulação de capital em detrimento de benefícios para a classe trabalhadora. A balança da luta de classes continua pendendo para um lado só.

\section{IV.4 - Novas formas de exploração do trabalho}

Pretende-se, no presente tópico mostrar como a já citada re-estruturação produtiva da passagem pós-fordista impactou na forma de exploração da classe trabalhadora. Ressalta-se, todavia, que a exploração do trabalho não é algo novo. Conforme já fora afirmado ao longo de todo o nosso estudo, a subsunção do trabalho ao capital é uma necessidade constante do capitalismo, sendo certo que, com a adoção das técnicas da gerência japonesa, apenas o que verificamos de plano é que a espoliação da classe trabalhadora foi colocada em novo patamar.

Note-se que afirmamos "novas formas de exploração". Isso porque elas sempre existiram e continuarão existindo enquanto vivermos sob o modo de produção capitalista. O "novas" aqui se refere ao novo modelo de apropriação do valor gerado pelo trabalhador, muitas vezes maquiado por ideia de co-participação e maior autonomia para quem trabalha. Ressalta-se, entretanto, que o antigo modelo não foi de todo substituído, sendo certo que as "velhas" formas de exploração persistem no que forem compatíveis com a gerência toyotista. Como já fora afirmado, a diferença entre os modelos de gerência se dá apenas no plano da organização técnica do trabalho voltada para as necessidades mercadológicas, sendo que a questão estrutural do trabalho explorado persiste. Assim, não houve uma suplantação de técnicas de exploração, apenas uma conciliação entre o velho e o novo no interesse do capital.

Ricardo Antunes, na introdução da obra "Riqueza e miséria do trabalho no Brasil", analisando os impactos da re-estruturação produtiva no caso do capitalismo brasileiro, afirma:

\footnotetext{
"No estágio atual do capitalismo brasileiro, enormes enxugamentos da força de trabalho combinam-se com mutações sociotécnicas no processo produtivo e na organização do controle social do trabalho. A flexibilização e a
} 
desregulamentação dos direitos sociais, bem como a terceirização e as novas formas de gestão da força de trabalho implantadas no espaço produtivo, estão em curso acentuado e presentes em grande intensidade, coexistindo com o fordismo, que parece ainda preservado em vários ramos produtivos e de serviços, com se pode constatar na gama compósita e heterogênea presente em nosso universo de pesquisa. Mas quando se olha o conjunto da estrutura produtiva, pode-se também constatar que o fordismo periférico e subordinado, que foi aqui estruturado, cada vez mais se mescla fortemente com novos processos produtivos, em grande expansão, consequência da liofilização organizacional, dos mecanismos próprios oriundos da acumulação flexível e das práticas toyotistas que foram e estão sendo assimiladas com vigor pelo setor produtivo brasileiro" 83

Antunes retrata bem o cenário que vislumbramos na atualidade da gerência e organização da força de trabalho. No caso brasileiro, temos uma mescla de elementos fordistas e toyotistas coexistindo nas empresas e nas linhas fabris, colaborando para um cenário de super exploração caótico.

As novas formas de gestão da força de trabalho, aliadas ao desmonte da estrutura de proteção social estatal ao longo da década de 90, criaram um cenário desalentador para a classe trabalhadora. De um lado os interesses dos empregadores que precisavam alterar suas estruturas produtivas para competirem nos mercados cada vez mais dinamizados; de outro, os trabalhadores que exerciam função chave nesse contexto, qual seja, o da produção de mercadorias.

Antunes também afirma, analisando a implementação das nova técnicas de gestão no setor bancário, que:

“os programas de qualidade total e de remuneração variável, amplamente difundidos no setor, recriaram estratégias de dominação do trabalho que procuram obscurecer e nublar a relação entre capital e trabalho. Os trabalhadores bancários foram constrangidos a tornar-se 'parceiros', 'sócios', 'colaboradores' dos bancos e das instituições financeiras, num ideário e numa prática que aviltam ainda mais a condição laborativa" ${ }^{" 44}$

Notemos que o autor faz referência direta ao setor bancário, porém os ditos

83 ANTUNES, Ricardo (org.). Riqueza e miséria do trabalho no Brasil. São Paulo: Biotempo, 2006. p. 19. 84 Idem. p. 21 
"programas de qualidade total" e "remuneração variável" são características marcantes da re-estruturação produtiva toyotista, tal qual já afirmamos anteriormente. O fato do autor se utilizar do setor bancário para fazer o exemplo, de maneira nenhuma inviabiliza a generalização da crítica, ao contrário a facilita pois é nos bancos que identificamos o que há de mais sofisticado em matéria de exploração. As características toyotistas anunciadas se fazem presentes em diversos setores da produção e, tal qual no exemplo utilizado por Antunes, também impõem aos trabalhadores as condições de "sócios" e "parceiros" do empreendimento comercial, aviltando "ainda mais a condição laborativa".

Marcia Hespanhol Bernardo - no livro "Trabalho duro, discurso flexível: uma análise das contradições do toyotismo a partir da vivência de trabalhadores" que analisa as condições impostas à classe obreira a partir da experiência dos próprios trabalhadores, com vasto trabalho de campo e entrevistas com trabalhadores - faz um relato bem semelhante das situações as quais as pessoas que trabalham são submetidas por conta dessas politicas de "parceria" entre capital e trabalho.

Nesse sentido, a partir de relatos de sindicalistas, a autora afirma:

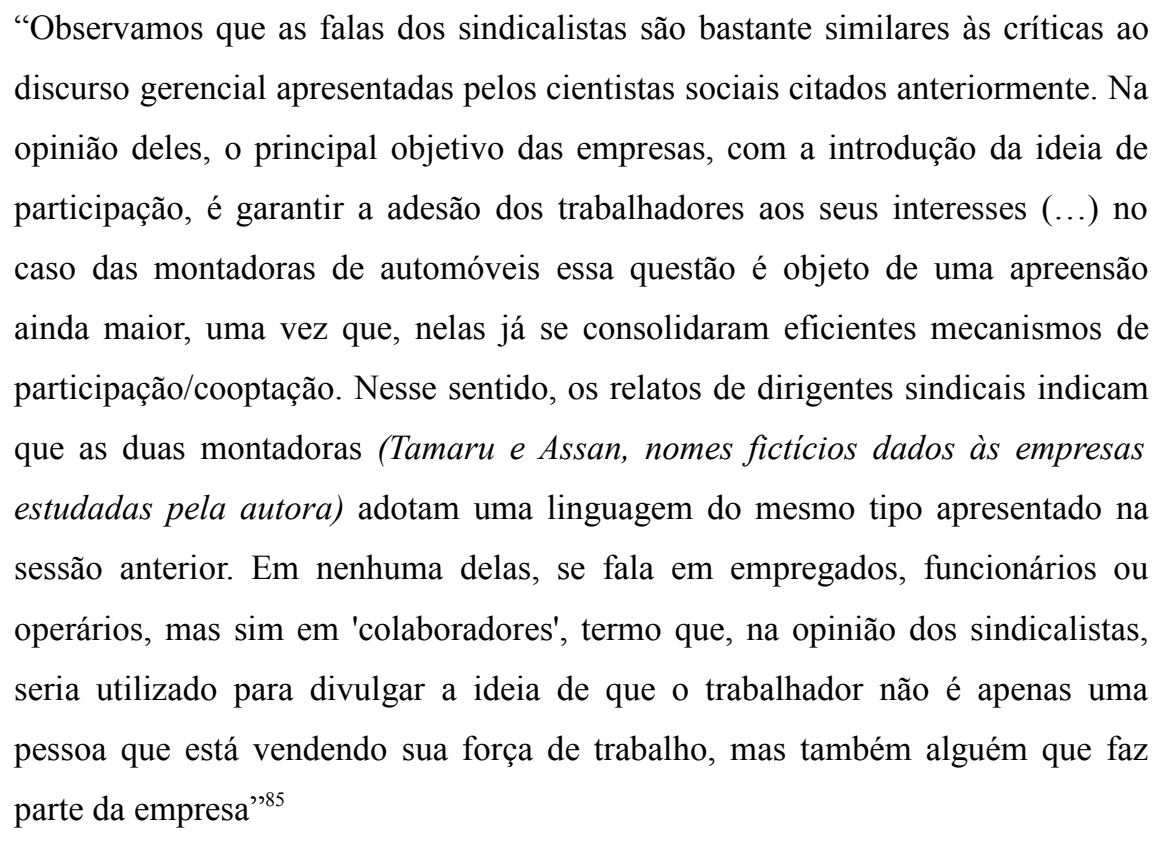

No relato feito pela autora, a exploração do trabalho se consolida de maneira mais

85 BERNARDO, Marcia Hespanhol. Trabalho duro, discurso flexível: uma análise das contradições do toyotismo a partir da vivência de trabalhadores. São Paulo: Expressão Popular, 2009. pp. 69-70. 
subjetiva do que a que estávamos acostumados a vislumbrar no paradigma fordista/taylorista. Incluir o trabalhador na empresa e cooptá-lo para os interesses de seu empregador é uma forma cruel de exploração, pois além de toda a espoliação a que o trabalho já submetido, com extração de mais-valia, estranhamento e alienação, essa técnica de gerência mascara as relações de trabalho e enebria o conflito inerente entre capital e trabalho.

Contudo, as forma de exploração do trabalho no paradigma da acumulação flexível não se mostram sempre tão sutis e elegantes, se é que assim podemos denominar.

Conforme pudemos verificar no trecho acima citado, um dos temas tratados pela autora para definir os impactos dessas novas técnicas de gestão na forma como o trabalhador lida e se envolve com seu trabalho é o da cooptação. A partir de referências teóricas e visões dos trabalhadores, a autora defende, que as empresas, ao adotarem políticas de participação e igualdades nas linhas produtivas, acabam por fazer com que o trabalhador apenas reproduza a sua própria lógica empresarial sem nenhum comprometimento com seus interesses ou de seus pares.

Assim, cita umas das montadoras que havia implantado um procedimento chamado de "portas abertas", ou seja, havia uma noção deturpada de hierarquia. Óbvio que apenas para os que estavam hierarquicamente inferiores dentro da empresa, assim os trabalhadores eram incentivados a se comunicarem diretamente com seus superiores para reportar as condições de produção. Porém esse "canal de comunicação" acaba por ser usado, na maioria das vezes, por trabalhadores para reportarem irregularidades cometidas por outros trabalhadores.

Dessa maneira, a autora afirma, utilizando-se de uma de suas entrevistas, que:

\footnotetext{
“João (trabalhador da Tamaru) avalia que a empresa incentiva esse tipo de atitude porque tem interesse em que os trabalhadores denunciem aqueles que não estão agindo conforme as regras, mesmo que sejam ocupantes de cargos de confiança. E, se os chefes dos níveis superiores avaliarem que a denúncia não tem fundamento, simplesmente não a levam em consideração", ${ }^{86}$
}

86 Idem. p. 72. 
Esse relato é bem emblemático, na medida em que mostra os níveis de cooptação usados pelas empresas: ao mesmo tempo que o trabalhador se sente parte integrante de uma "equipe", que é a empresa - coisa que ele não é e nem deve ser pois não possui o capital - a competição e hostilidade são incentivadas entre os empregados, garantindo - e até aprofundando - a manutenção do poder de direção, pois quem decide o que fazer são os superiores, sem dar qualquer justificativa.

Outro ponto evidenciado pela pesquisadora diz respeito à formação de grupos de trabalho. A autora sustenta que esses grupos, longe de oferecerem uma maior possibilidade de atuação conjunta e coletiva dos trabalhadores, estimulam a competição entre os obreiros e fragmentam ainda mais a classe. Um dos exemplos citados é o que apresenta uma "célula" de trabalho, que só existe para e sobre jornada:

\footnotetext{
“Também observamos que, se não existe uma associação clara do conjunto dos postos de trabalho que compõem a 'célula' com a ideia de grupo no cotidiano dos trabalhadores, essa identificação grupal é lembrada pelas chefias no momento de 'solicitar' que se faça hora extra. Nesse caso, serve como estratégia para conseguir que os trabalhadores se controlem mutuamente, uma vez que aqueles que não ficam após sua jornada oficial de trabalho podem ser culpabilizados pela sobrecarga dos colegas que aceitam permanecer. Isso ocorre porque a meta de produção coletiva é fixada contando com as horas extras independentemente da informação prévia de quantos funcionários permanecerão após o turno de trabalho e, assim, quanto menos trabalhadores ficarem nesse período, maior será sua sobrecarga" ${ }^{\prime 87}$
}

Essas práticas empresariais, que se revestem de uma aura de igualdade e colaboração, na verdade só fazem por aprofundar as desigualdades e a competição entre os trabalhadores. Nesse sentido, a autora confirma:
"Os trabalhadores que participaram de nossa pesquisa são praticamente unânimes em dizer que, de fato, tanto a Assan quanto a Tamaru estimulam a competição e, obviamente, sempre no sentido de beneficiar aqueles que apresentem um espírito mais favorável à suas proposições" ${ }^{98}$

Essa concepção, todavia, não é partilhada por todos os trabalhadores. O processo

87 Idem. p. 102.

88 Idem. p. 108. 
de cooptação das empresas funciona e, em muitos casos, o empregado passa a crer que faz parte de uma estrutura empresarial menos formal, só tendo a ganhar com a colaboração. Ocorre que, ainda que a colaboração tenha como reflexo melhores salários, devemos pontuar que, se por um lado, a colaboração satisfez o trabalhador momentaneamente, por outro implicou na reprodução de uma lógica gerencial nefasta que só faz por oprimir e explorar ainda mais a classe obreira como um todo.

A divisão da classe trabalhadora é um dos principais objetivos da gerência científica. Paula Regina Pereira Marcelino, analisando o caso da montadora de automóveis Honda, em artigo publicado no livro "Riqueza e miséria do trabalho no Brasil", afirma o seguinte:

\footnotetext{
"A recomposição do domínio capitalista com um processo social global passa, necessariamente, pelo local de trabalho. Nele também é fundamental que se mine a união entre os trabalhadores, sua organização enquanto classe, a identidade que faz cada trabalhador enxergar no outro um aliado. Perdas sucessivas de direitos e divisão entre os trabalhadores são processos que se alimentam um do outro" 89
}

O enfoque da autora é a terceirização na gestão empresarial da Honda. Assim, a pesquisadora afirma que a empresa, na tentativa de obter essa fragmentação, coloca trabalhadores terceirizados e empregados da montadora trabalhando juntos, realizando atividades semelhantes, fazendo suas refeições no mesmo refeitório, porém, com uniformes distintos. Isso gera nos próprios trabalhadores uma sensação de que não são iguais. E não são mesmo, na medida em que seus salários são diferentes e os direitos também, já que as convenções coletivas firmadas entre a Honda e o sindicato representativo de seus empregados não abrange os terceirizados. A questão da representação sindical é só um dos problemas que essa política gera. Além dele, temos a questão dos salários reduzidos, da falta de identificação de classe, da discriminação no ambiente de trabalho, entre tantos outros.

Pois bem. Demonstramos até aqui que as técnicas gerenciais da chamada acumulação flexível acabam por gerar uma situação de super exploração do trabalho, que

89 MARCELINO, Paula Regina Pereira. Honda: Terceirização e precarização a outra face do toyotismo in ANTUNES..op. cit. 
muitas vezes é até consentida pelo trabalhador. Nesse sentido podemos chamar de novas tais formas de exploração, em contraposição ao paradigma fordista de extração da maisvalia na linha de montagem..

Ressalta-se, todavia, que o antigo modelo de exploração não foi suplantado, mas apenas incrementado por essas novas práticas empresariais e, nesse sentido, o direito deve conhecê-las para poder abarcá-las. O paradigma fordista está desatualizado e, por consequência, uma legislação trabalhista gestada nesse contexto também. Não se trata aqui de defender a atualização da legislação trabalhista a partir de um novo modelo, que certamente daria margens a desregulamentações que não apoiamos. Mas sim de uma atualização que faça o mesmo caminho das relações que se pretende tutelar. Se já existe uma legislação protetiva para o paradigma fordista, e esse não foi suplantado, mas apenas incrementado, que o direito também o faça . Que incrementemos os nossos freios jurídicos, mantendo a estrutura e buscando novos caminhos no mar da gerência flexível. É o que tentaremos fazer em nosso derradeiro capítulo. 


\section{V - AS RESPOSTAS DO DIREITO \\ V.1 - O verdadeiro caráter do trabalho subordinado}

Dispõe o artigo $2^{\circ}$ da CLT:

\footnotetext{
"Considera-se empregador a empresa, individual ou coletiva, que, assumindo os riscos da atividade econômica, admite, assalaria e dirige a prestação pessoal de serviço"
}

Analisando o texto legal, conseguimos auferir a estrutura jurídica que a lei deu ao trabalho subordinado. Mais do que analisarmos esse preceito à luz do que diz a legislação sobre o empregado, é importante que tomemos por base o que a CLT dispõe sobre o que é considerado empregador.

Muito se diz sobre a necessidade de atualização da legislação trabalhista. Isso porque, para alguns críticos, uma lei de 1943 não pode ter condições de dar conta de toda a complexidade das relações de trabalho no século XXI. Contudo, percebemos que boa parte dessa crítica - para não dizer a totalidade - é fundamentada em referenciais de desregulamentação e diminuição da proteção ao trabalhador .

Voltemos ao texto legal. Dois conceitos insculpidos no artigo acima transcrito são de fundamental importância para nosso estudo: "riscos da atividade econômica" e "dirige a prestação pessoal de serviço". Os riscos da atividade econômica são, por excelência e definição, do empregador, da empresa. Muitas das formas de precarização do trabalho que foram objeto de nossa explanação anterior buscam justamente compartilhar com o trabalhador tais riscos, sendo exemplo claro disso a subcontratação, ou terceirização para fora.

Um trabalhador que atua através de uma Pessoa Jurídica - muitas vezes apenas acrescentando a terminação ME a seu próprio nome - sendo, todavia, verdadeiro empregado de uma outra empresa que toma seus serviços mas o trata como "parceiro" de negócios, está sujeito às mesmas intempéries do mercado que seu empregador, como se exercesse verdadeira atividade empresária.

O vínculo de emprego, para além de todas as garantias, proteções, e implicações sociais de cunho previdenciário, também, representa uma garantia de que, ao final do mês, 
o salário do trabalhador lhe será pago, independentemente das condições favoráveis ou não dos mercados. Ainda que em nosso ordenamento não vigore - para quase a totalidade da doutrina e da jurisprudência - a proteção contra a dispensa arbitrária, não há como negarmos que o vínculo formal de emprego ainda representa uma garantia ao trabalhador.

Desse modo, é temerária a noção de compartilhamento dos riscos da atividade econômica, na medida em que o trabalhador empregado não é detentor dos meios de produção. Assim, da mesma forma com que ele não fica com os lucros - muita vezes exorbitantes - da atividade empresária, também não é razoável que ele arque com os prejuízos advindos de um momento econômico adverso sob pena de se criar um sacrífico sem qualquer contrapartida, o que não deve ser tolerado pelo direito.

O outro conceito citado, que se relaciona intimamente com nosso estudo é o da direção da prestação de serviços. Márcio Túlio Viana, analisando os aspectos históricos da subordinação do trabalho ao capital afirma:

\footnotetext{
"Mais tarde, o relógio se torna cronômetro, passando a servir não só para marcar entradas e saídas, mas para ditar ritmos e movimentos (...) Já agora, não bastava trabalhar para outro, seguindo os seus horários, usando as suas máquinas e obedecendo à disciplina geral; era preciso moldar o corpo às regras ditadas pela gerência, realidade que a CLT iria colher e traduzir na definição de empregador (é aquele que 'dirige' - art. $\left.2^{\circ}\right)^{, 90}$
}

Já tratamos em momento anterior da questão da gerência científica nas relações de trabalho. E é justamente a isso que se refere o autor quando afirma que a CLT colheu e traduziu na expressão "dirige" a obediência "às regras ditadas pela gerência". Se o empregador, escolhendo exercer atividade empresária, adota os procedimentos de organização do trabalho e da produção que se moldam melhor aos seus objetivos, impondo esses ritmos e rotinas de trabalho ao empregado, nada mais correto que ele seja enquadrado como empregador por "dirigir” a prestação de serviços.

Caso contrário, há sempre a possibilidade do empresário abandonar sua atividade e ir ativar-se como empregado de outrem. Quem atua na direção da prestação de serviços

90 VIANA, Marco Tulio. Trabalhadores Parassubordinados: Deslizando para Fora do Direito in RENAULT, Luiz Otávio Linhares (et al.). Parassubordinação: em homenagem ao Professor Màrcio Túlio Viana. São Paulo: LTr, 2011. p. 26 
tem uma responsabilidade, que é a de propriamente organizar a realização do trabalho. Não é possível imputar ao trabalhador ainda mais esse ônus. $\mathrm{O}$ indivíduo que trabalha não tem qualquer liberdade na execução de seu trabalho, não possui qualquer condição material de ser igualado ao empregador, não pode arcar com os ônus do exercício da atividade empresária, até porque o trabalhador não a exerce.

Um exemplo - ainda que positivista - que ilustra muito bem o que estamos tratando é a vedação à concessão dos benefícios da justiça gratuita ao empregador. Para além do argumento meramente legal, ${ }^{91}$ que impede a concessão desse benefício à reclamada, entendemos ser razoável esse entendimento a partir da noção de que se o empresário explora a força de trabalho alheia, ele já gozou de prerrogativas e condições que não podem o igualar ao trabalhador e, sendo assim, não seria justo que processualmente as duas partes tivessem os mesmos benefícios. Esse é apenas um exemplo, entre tantos outros poderiam ser fornecidos.

O trabalho subordinado é o trabalho explorado, e a exploração do trabalho, conforme já dissemos, é a essência do capitalismo. Ainda que se defenda o capitalismo, deve-se e admitir que a exploração do trabalho existe. Entendemos que a exploração do trabalho alheio não é algo positivo, contudo é plenamente possível que exista quem ache que é, desde que as defesas dos posicionamentos sejam feitas às claras, no espaço público e democrático da argumentação.

Dessa forma - firmes no entendimento de que o trabalho explorado representa uma das essências do capitalismo, por detrás de todas as possíveis aparências tomadas por essenciais que o próprio capitalismo produz e reproduz, e que o direito muitas vezes nada mais faz do que revestir de aparência complexa algumas essências óbvias da realidade social - podemos afirmar que o trabalho subordinado é o trabalho explorado, bem como que a subordinação jurídica é a exploração do trabalho pelo capital. É assim que propomos o entendimento da questão para melhor colocação do problema e seu devido enfrentamento.

91 Uma exegese do artigo 14 da lei 5584/70 que regula a matéria indica que como é usada a expressão "categoria profissional" apenas os reclamantes tem direito ao benefício da assistência judiciária gratuita. A lei 10537/02 que modificou o texto do artigo 790 da CLT trouxe novos contornos e argumentos para esse debate, contudo entendemos que essas modificações não alteram significativamente os termos da discussão. 


\section{V.2 - Retratos de uma subordinação jurídica}

O presente tópico foi inspirado no artigo "A Subordinação sem Derivações Semânticas" de Luiz Otávio Linhares Renault e Dárlen Prietsch Medeiros, inserido na já citada obra "Parassubordinação: Homenagem ao Professor Márcio Túlio Viana".

No referido artigo, os autores fazem um apanhado das teorias sobre a subordinação no direito do trabalho. Eles partem de uma perspectiva crítica acerca da teoria da parassubordinação, que busca dar um nome, ser uma "derivação semântica", para um conceito que, no fundo, serve para mitigar a proteção do trabalhador na esfera jurídica da relação de emprego.

Ao fazerem uma abordagem teórica sobre as novas formas empresariais de contratação e "enxugamento" da empresa moderna, os autores concluem que:

\footnotetext{
“Com efeito, nos últimos anos, novas teorias têm surgido para explicar e justificar a subordinação existente na relação entre empregado e empregador. Atualmente, com base nessas teorias, a subordinação tem sido exibida com novas roupagens, ou mesmo travestida. Como a subordinação possui diversos matizes, quando ela se apresenta tenuemente, procura-se, por vezes, fazer o seu apagamento, excluindo alguns trabalhadores do seu âmbito de incidência" ${ }^{\prime 2}$
}

Conforme já fora afirmado, a subordinação é o elemento essencial para definição da relação de emprego - essa relação jurídica que define toda a gama de incidência do direito do trabalho. Assim, excluir alguns trabalhadores do âmbito de incidência da subordinação implica excluí-los da própria proteção do direito trabalhista.

A partir de então, os autores passam a expor correntes do direito do trabalho que buscam um novo modelo para a caracterização da subordinação no âmbito jurídico, motivo pelo qual intitulamos esse tópico de "Retratos de uma subordinação jurídica". São muitas as teorias, conforme, que buscam dar novas roupagens a esse instituto, algumas com maior outras com menor grau de eficácia para a proteção do trabalhador. Todas, entretanto, têm um ponto em comum: entendem que, no momento atual de desenvolvimento da organização do trabalho, a antiga forma de caracterização do trabalho subordinado é insuficiente para a necessária configuração da relação de emprego e a incidência do direito 92 RENAULT, Luiz Otávio Linhares e MEDEIROS, Dárlen Prietsch. A Subordinação sem Derivações Semânticas in Parassubordinação... p. 185 
do trabalho.

\title{
A primeira das teorias da subordinação que iremos tratar é a chamada subordinação estrutural:
}

\begin{abstract}
"Idealizada pelo jurista e professor Mauricio Godinho Delgado, que propõe uma adequação ou renovação do conceito de subordinação para permitir alargar o campo de incidência juslaborativa e conferir resposta normativa aos recentes instrumentos desestabilizadores, a subordinação estrutural parte do conceito de subordinação objetiva, que desponta da simples integração da atividade do trabalhador nos fins da empresa (...) propõe que o conceito de subordinação deva ser revisto para que sejam considerados subordinados aqueles empregados cujas atividades desenvolvidas se integrem aos objetivos empresariais" ${ }^{93}$
\end{abstract}

A inserção do trabalhador na dinâmica organizacional de produção da empresa sem que ele esteja diretamente envolvido na organização empresarial - já faria com que fosse possível considerá-lo subordinado, e por isso empregado da empresa que toma parte do produto de seu trabalho. Indiscutivelmente, essa teoria é um avanço e devemos considerá-la na forma de readequação da subordinação para os fins jurídicos a que ela se presta.

A subordinação estrutural possui um elemento de exploração do trabalho muito importante: a integração do trabalhador aos objetivos da atividade econômica desenvolvida por uma empresa que, ainda que indiretamente, contrate seus serviços. Nada mais acertado, tendo em vista que a força de trabalho do empregado estará sendo explorada pela empresa, na medida em que o valor gerado pelo trabalho humano estará sendo utilizado para a criação de mercadoria e a geração de lucros.

Outra teoria é a da subordinação reticular, que os autores definem da seguinte maneira:
“A expressão subordinação reticular foi originalmente proposta por José
Eduardo de Resende Chaves Júnior e Marcus Menezes Barberino Mendes. De acordo com ela, esse pressuposto não poderia mais ser visto apenas sob o prisma jurídico. Indispensável a sua ampliação para o aspecto econômico, visando-se, com ela, a ampliação do alcance das normas trabalhistas (...) o modelo atual

93 Idem. p. 189 
apresenta empresas interligadas em rede, que no final dessa cadeia irão beneficiar uma empregadora. A partir daí, tem-se que, havendo subordinação econômica entre a empresa prestadora de serviços e a tomadora, esta seria diretamente responsável pelos empregados daquela, configurando a subordinação estrutural reticular"94

A importância dessa teoria se destaca na configuração da relação de emprego de trabalhadores que, na maioria das vezes, prestam serviços para empresas que sequer possuem capital para poder explorar o trabalho alheio, servindo apenas como forma de burla à legislação trabalhista. Temos como exemplo extremo dessa subordinação o recente caso da famosa e "sofisticada" casa de roupas Zara". Recentemente, agentes de fiscalização do Ministério do Trabalho descobriram que uma oficina de costura em São Paulo, que produzia peças para tal loja, mantinha trabalhadores em condição de escravidão.

O trabalho escravo na Zara fora logo denunciado pela mídia como um furo jornalístico, sendo certo que a própria imprensa - ainda que sem nenhuma intenção - se apressou em utilizar a subordinação reticular para ligar o trabalho escravo à casa de roupas. O processo judicial, no entanto, segue. Dependendo da perspicácia dos advogados da Zara $^{96}$ e do entendimento do juiz da causa, a grife pode não ser responsabilizada pela lesão de direitos cometida pela oficina de costura por si contratada. E pior é que, caso a oficina de costura contratada não possua bens - como não deve possuir - para arcar com toda a reparação que os trabalhadores que foram desumanizados fazem jus, eles podem ficar sem receber nada.

É justamente isso que a teoria da subordinação reticular busca mitigar. Assim como esse caso ilustrativo, muitos outros acontecem diariamente e, quase sempre, as empresas tomadoras dos serviços - e economicamente subordinadora da que lhe presta serviços conseguem se valer de artifícios legais para se livrarem de qualquer responsabilidade.

94 Ibidem. pp. 189-90

95 http://www.reporterbrasil.org.br/exibe.php?id=1925 acesso em 17/11/2011

96 Os responsáveis pela marca já se apressaram em falar que desconheciam a existência de trabalho escravo nas oficinas, falaram que a responsabilidade por isso era das empresas prestadoras de serviço e "se comprometeram" a evitar que isso aconteça novamente. Ainda sobre o assunto:

http://exame.abril.com.br/negocios/empresas/noticias/zara-diz-que-desconhecia-trabalho-escravo-em-suas e http://www.estadao.com.br/noticias/geral,apos-acusacoes-zara-cria-disque-denuncia-de-trabalhoescravo,772606,0.htm acesso em 17/11/2011. 
Outra dimensão das teorias sobre a subordinação é a da subordinação integrativa:

\begin{abstract}
"Formulada por Lorena Vasconcelos Porto, a subordinação integrativa não visa abandonar a subordinação clássica, mas, sim, acrescer aos conceito tradicional uma nova dimensão, que seria resultante da interpretação das leis e da jurisprudência, portanto, sem necessidade de legislar sobre a matéria (...) preleciona a autora que, considerando as críticas à subordinação objetiva, a solução passaria pela conjugação dessa acepção com critérios excludentes da autonomia. Portanto, após a constatação de subordinação objetiva, o intérprete deve verificar se estão presentes alguns indícios da ausência de autonomia, para então concluir pela configuração de subordinação integrativa (...) Dessa forma, pode-se concluir que a subordinação integrativa ocorre quando a prestação de trabalho integra as atividades exercidas pelo empregador e o trabalhador não apresenta as características de um autônomo"97
\end{abstract}

O conceito de subordinação integrativa é importante para a configuração da relação de emprego pela negativa do trabalho autônomo. Muitas vezes, as empresas buscam formas de contratação que, supostamente, dão ao trabalhador uma liberdade na prestação de serviços justamente para enquadrá-lo como um profissional autônomo. E muitas vezes, ao contrário, o trabalhador é verdadeiramente autônomo e, por isso, não deve haver a incidência das normas de tutela da relação de emprego. A distinção pela negativa serve tanto para afirmar quanto para negar um conceito.

Deixamos por último, por sua similitude com o que anteriormente expusemos sobre o caráter do trabalho subordinado, o conceito que foi primeiro exposto pelos autores: o da supersubordinação.

O conceito de supersubordinação, criado por Jorge Luiz Souto Maior, busca uma forma de representação de uma relação que a partir da exploração do trabalho - a despeito das tentativas empresariais - possa ser enquadrada na hipótese de incidência do direito do trabalho. Ao fazer uma abordagem inicial da questão, passando pelos nomes que o direito cria para determinados conceitos, especificamente, o da parassubordinação, o autor faz uma pertinente colocação:

“O capital, que é quem controla a forma de correlação entre si e o trabalho,

97 Op. cit. p. 191. 
sabendo do parâmetro jurídico intermediário criado, no qual os direitos trabalhistas são menos evidentes, trata, então, de transferir todos os antigos empregados para a 'nova' situação. Assim, do ponto de vista geral, em vez de se ampliar o leque social de incidência do Direito do Trabalho, caminha-se em direção contrária" 98

No caso tratado pelo autor, o "parâmetro jurídico intermediário" é a parassubordinação, que cria uma categoria entre os profissionais autônomos e os empregados com o intuito de levar a proteção do direito do trabalho para um grupo de trabalhadores que, por possuírem características de subordinação diferenciadas e difíceis de enquadrar nas hipótese clássica da subordinação jurídica, são considerados autônomos e por isso sem regulamentação trabalhista.

Souto Maior, todavia, critica justamente a criação de categorias intermediárias de proteção mitigada. A teoria do direito do trabalho, até por toda sua principiologia de afirmação dos direitos sociais e melhoria da condição do trabalhador, não deve jamais trabalhar com conceitos que signifiquem a redução da proteção trabalhista, sob pena de estarmos permitindo o retrocesso e a diminuição da tutela das relações de trabalho no sentido da proteção do trabalho e do trabalhador.

É nesse contexto que se insere a supersubordinação. Souto Maior afirma, em posicionamento que já adotamos ao longo do presente estudo, que a forma de contratação de mão-de-obra através do emprego é um pressuposto da organização do trabalho e da produção capitalista, "a presença de massas de trabalhadores subordinados atende, aliás, às exigências da técnica produtiva e do seu natural progresso" 99 , assim conclui que "a ideia central da incidência do Direito do Trabalho é o trabalho sob dependência alheia". ${ }^{100}$ Dessa forma, ganha importância a busca pela identificação da subordinação:

\footnotetext{
"Identificar a subordinação nesses novos arranjos do mundo do trabalho é relevante não para se fazer uma apologia da subordinação, mas para deixar claro que ela existe e, assim, para que se faça a necessária incidência das garantias do Direito Social na realidade, pois, afinal, foi essa ficção jurídica que se criou para identificar a relação de emprego, que, por sua vez, representa a expressão que
}

98 MAIOR. Jorge Luiz Souto. A supersubordinação in Parassubordinação...Op. Cit. p. 60 99Idem, p. 65 100 Ide, p. 66 
retrata a exploração do trabalho alheio numa lógica produtiva"101

Percebe-se, pela passagem acima, que a subordinação no âmbito do direito do trabalho e da relação de emprego é uma ficção jurídica e é assim que a devemos tratá-la. De nada adianta afirmarmos a importância da subordinação jurídica, se não soubermos o que ela exatamente representa e se representa realmente algo de concreto. Se o trabalho subordinado representa o trabalho explorado, podemos afirmar que a subordinação - ainda que ficção - é umas das facetas da exploração do trabalho. Nesse sentido conclui Souto Maior pela afirmação de seu conceito de supersubordinação:

“Assim, se há uma relação de trabalho, pela qual o trabalho alheio é utilizado para o desenvolvimento de um projeto de acumulação de capital, sem o efetivo respeito aos direitos sociais (que servem, muitos deles, para preservação da saúde e para o convívio social e familiar), quebra-se o vínculo básico de uma sociedade sob a égide do Estado de Direito Social. O dado da exploração é o único que sobressai. É a exploração pela exploração, nada mais. Aliás, a ausência de compensação de natureza social gera uma superexploração. Jurídicamente falando, a subordinação se potencializam fazendo surgir então, a figura da supersubordinação"102

$\mathrm{O}$ autor, ao afirmar que esse desrespeito sistemático aos direitos sociais do trabalhador é "a exploração pela exploração", deixa sobressair um dado do direito do trabalho que já afirmamos: sua contradição entre afirmação de melhores condições para o trabalhador e a regulação racional e efetiva do modo de produção capitalista. Percebe-se, assim, que a "exploração pela exploração" não serve sequer ao capitalismo, na medida em que o trabalho explorado cumpre uma função fundamental de produção de mercadorias que devem ser consumidas pela própria massa de trabalhadores em condições de reprodutibilidade.

Precisamos, para mitigar os efeitos nefastos da exploração, desvendar a fórmula da subordinação jurídica, que serve de base para a configuração da relação de emprego e a incidência toda do direito do trabalho. Os novos conceitos de subordinação, que foram aqui expostos, muito podem nos auxiliar na busca pelo aperfeiçoamento dos freios jurídicos, tais como "retratos" de uma espécie de subordinação, 
Como momento final de nosso trabalho, iremos abordar a forma como o judiciário encara - se é que encara - as questões aqui tratadas. Pretendemos, ao inserir um capítulo de jurisprudência comentada nessa dissertação, mostrar como a teoria que expusemos até aqui torna-se a prática de nossos tribunais. 


\section{VI - COMO OS TRIBUNAIS ENXERGAM TUDO ISSO (JURISPRUDÊNCIA COMENTADA)}

A ideia de fazer um capítulo de jurisprudência comentada surgiu ao longo da elaboração do texto final da dissertação. Apesar de não previsto no sumário inicial, comentar decisões judiciais afetas ao nosso tema de estudo nos pareceu uma importante forma de dar contornos concretos ao que tratamos até aqui. Mais do que falar como deveria ser o enquadramento jurídico da relação de emprego e como o direito deveria entender o elemento da subordinação, preferimos mostrar como parte do judiciário tem visto essas questões, bem como formularmos comentários críticos acerca dessas decisões.

A forma como os juízes interpretam e conferem efetividade à lei, ainda que no caso concreto e individualizado, é um importante fator de eficácia da norma, que no direito do trabalho está imbricada com preceitos de proteção do trabalhador e justiça social. Infelizmente a prática que vemos em nossos tribunais não vai nesse sentido, contudo a jurisprudência também é um elemento de disputa pelo direito.

Inicialmente cumpre explicitarmos algumas questões formais: o presente capítulo não tem por objetivo ser um estudo exaustivo da jurisprudência sobre a matéria subordinação. Escolhemos algumas decisões que mereciam destaque pela pertinência temática e relevância doutrinária. Além disso, ressalta-se que o inteiro teor dos acórdãos comentados, quando eles estavam disponíveis para consulta, seguem no Anexo ao final da dissertação.

Por fim, destacamos a atualidade do assunto que tratamos nesse estudo, que pode ser conferida até mesmo pela data de publicação das decisões analisadas. Das 13 ementas comentadas, 3 são de 2009, 2 são de 2010 e 8 são de 2011. Assim, além da importância estrutural já destacada ao longo de nosso trabalho a discussão aqui travada também é atual. As concepções sobre o direito do trabalho continuam em pauta e não podemos nos furtar a tomar uma posição, já que a inércia não favorece quem quer a mudança.

Passemos, pois à ementas e aos comentários propriamente ditos.

"RECURSO DE REVISTA. VÍNCULO DE EMPREGO. EMPRESA DE TELECOMUNICAÇÃO. TERCEIRIZAÇÃO DE ATIVIDADE-FIM. 1.1.-Serviço de telecomunicações é o conjunto de atividades que possibilita a oferta de telecomunicações-, por intermédio de -transmissão, emissão ou 
recepção, por fio, radioeletricidade, meios ópticos ou qualquer outro processo eletromagnético, de símbolos, caracteres, sinais, escritos, imagens, sons ou informações de qualquer natureza- (art. 60, -caput- e $\S 1^{\circ}$, da Lei $n^{\circ}$ 9.472/97). 1.2. Os serviços de telecomunicações vinculados à implantação e manutenção de redes de acesso, equipamentos e sistemas de telecomunicações estão inseridos nas atividades essenciais das empresas concessionárias dos serviços de telecomunicações, circunstância que desautoriza a prática da terceirização. 1.3. O $\S 1^{\circ}$ do art. 25 da Lei ${ }^{\circ} 8.987 / 95$, bem como o inciso II do art. 94 da Lei $\mathrm{n}^{\circ}$ 9.472/97 autorizam as empresas de telecomunicações a terceirizar as atividades-meio, não se enquadrando em tal categoria os instaladores de redes, eis que aproveitados em atividade essencial para o funcionamento das empresas. 1.4. Rememore-se que o conceito de subordinação deve ser examinado à luz da inserção do trabalhador na dinâmica do tomador de serviços, configurando a denominada subordinação estrutural, teoria que se adianta como solução para os casos em que o conceito clássico de subordinação se apresenta inócuo. Recurso de revista conhecido e provido."

(TST - RR 4240520105180054 424-05.2010.5.18.0054, Relator: Alberto Luiz Bresciani de Fontan Pereira, Data de Julgamento: 22/06/2011, Data de Publicação: DEJT 01/07/2011)

A decisão acima, do Tribunal Superior do Trabalho, trata de Recurso de Revista interposto pelo reclamante, trabalhador da empresa prestadora de serviços, que teve seu pedido de nulidade da terceirização e reconhecimento do vínculo de emprego diretamente com a empresa de telecomunicações negado tanto em primeira quanto em segunda instâncias. Como notamos, o recurso foi provido para, nos termos do voto do relator, "declarar a nulidade da contratação por empresa interposta, reconhecendo o vínculo de emprego diretamente com a primeira Reclamada".

A ementa analisada é precisa ao afirmar que o "conceito de subordinação deve ser examinado à luz da inserção do trabalhador na dinâmica do tomador de serviços, configurando a denominada subordinação estrutural, teoria que se adianta como solução para os casos em que o conceito clássico de subordinação se apresenta inócuo". No caso em tela, o reclamante recorrente prestava serviço para a empresa de telecomunicações exercendo a função de instalação de rede, ou seja, o trabalhador se ligava estruturalmente à atividade econômica da empresa, na medida em que a rede de telecomunicações para uma empresa de telecomunicações é algo relevante, senão fundamental, para a consecução das atividades empresariais.

No caso referido, a sanha por terceirizar serviços e reduzir custos é ainda maior, tendo em vista que, no caso das telecomunicações, a própria lei define o conjunto de atividades que possibilita a oferta de serviços, não havendo sequer justificativa legal para a interposição de mão-de-obra.

A próxima ementa aproxima-se muito do mérito da decisão anterior, no que 
concerne à nulidade da terceirização.

“TERCEIRIZAÇÃO - SUBORDINAÇÃO ESTRUTURAL - NOVA TENDÊNCIA- A subordinação, como requisito substancial, longe da visão clássica em que foi instituída a relação de emprego, quando o trabalhador estava submetido a uma disciplina rígida e direta do próprio empregador, tem, hoje, outros contornos diante das mutações das relações laborais, que ganham novo enfoque para se adequarem às exigências do mercado globalizado, sem afetar a principiologia protecionista que funda $o$ Direito do Trabalho. Trata-se de interpretação ampliativa desse elemento, cujo escopo é atingir trabalhadores que não se inserem no conceito clássico de subordinação, mas estão afetos ao comando do empreendimento empresarial, em razão da prestação laboral. A festejada subordinação estrutural "se manifesta pela inserção do trabalhador na dinâmica do tomador de seus serviços, independentemente de receber (ou não) suas ordens diretas, mas acolhendo, estruturalmente, sua dinâmica de organização e funcionamento". Recurso conhecido e não provido"

(TRT $16{ }^{\text {a }}$ Região/MA - RO 910200800216003 MA 00910-2008-002-16-00-3, Relator: LUIZ COSMO DA SILVA JÚNIOR, Data de Julgamento: 27/08/2009, Data de Publicação: 12/11/2009)

Essa decisão do Tribunal Regional do Trabalho da $16^{\mathrm{a}}$ Região se diferencia da decisão anterior do TST pela matéria in casu da terceirização. Enquanto a primeira decisão versava sobre a terceirização de serviços de telecomunicação, essa decisão trata da terceirização de serviços bancários. Enquanto o banco que recorria postulava pela legalidade do contrato de prestação de serviços, o voto do Desembargador relator entendeu pela aplicação do conceito de subordinação estrutural e pela manutenção do reconhecimento, em primeira instância, do vínculo de emprego do reclamante diretamente com a instituição bancária, já que as atividades desenvolvidas pelo trabalhador inseriam-se diretamente na dinâmica do tomador de serviços.

Contudo, um ponto que nos chamou a atenção no Acórdão analisado foi a seguinte passagem:
"Tratando-se de subordinação vista sob o enfoque da estrutura empresarial, é irrelevante o fato de o trabalhador prestar serviços em atividades fins ou meios do tomador, já que o que caracteriza a relação jurídica de emprego e, por via de consequência, a incidência das normas protetivas laborais, é, segundo o autor retrocitado, o fato de não agir no seio de uma organização própria antes de se integrar numa organização de meios produtivos alheia, dirigida à obtenção de fins igualmente alheios, o que implica de sua parte, a submissão às regras que exprimem o poder de organização do empresário, à autoridade deste, em suma, derivada da sua posição nas relações de produção"

Ainda que o relator tenha entendido que as funções do reclamante se inseriam dentro das atividades-fim da empresa, a referida passagem é de extrema importância e 
lucidez, na medida em que dá margem à uma interpretação que supera a dicotomia estabelecida entre fim e meio nas atividades empresárias que - além de não fazer muito sentido, como já observado anteriormente - só serve para justificar a terceirização e reduzir direitos dos trabalhadores.

O reconhecimento do vínculo de emprego diretamente com o banco é de extrema importância, se levarmos em conta as condições mais favoráveis estabelecidas pelas Convenções Coletivas dos bancários em comparação com os empregados terceirizados que, talvez, sequer tenham um sindicato para lhes representar. As próximas decisões tratam especificamente da questão bancária.

"VÍNCULO DE EMPREGO. CORRESPONDENTE BANCÁRIO. SUBORDINAÇÃO ESTRUTURAL. VÍNCULO DE EMPREGO DIRETO COM O BANCO. Se, no exercício das funções, o trabalhador executa tarefas inseridas no contexto das atividades essenciais ao processo produtivo do beneficiário dos serviços, não se exige, para análise do elemento subordinação, prova de expedição de ordens e fiscalização direta, tampouco a presença do trabalhador no estabelecimento do tomador. Basta que se passe a ordenar a produção, o que traduz uma nova forma de organização produtiva, que tem raiz na empresa-mater, e que se ramifica e forma uma nova espécie de subordinação. Esta, de acordo com a doutrina, denomina-se subordinação estrutural, em que o trabalho executado integra a estrutura da empresa, ao inserir o trabalhador na dinâmica empresarial do tomador de serviços, o que atrai a proteção das normas da CLT e, consequentemente, o reconhecimento de vínculo de emprego, especialmente quando evidenciada a presença de alteridade-alienamento em favor do tomador. Recurso ordinário do autor provido, para reconhecer o vínculo de emprego diretamente com o banco reclamado" (TRT 9ª Região/PR 22963-2009-1-9-0-8, Relatora: MARLENE T. FUVERKI SUGUIMATSU,, Data de Publicação: 04/10/2011)

“CONDIÇÃO DE BANCÁRIO. Comprovado que o empregado trabalha inserido dentro da organização do estabelecimento bancário, estando subordinado ao gerente da agência do banco, deve ter reconhecida a sua condição de bancário"

(TRT 4 ${ }^{\mathrm{a}}$ Região/RS - 0063100-09.2009.5.04.0023, Relator: CLÓVIS FERNANDO SCHUCH SANTOS, Data de Julgamento: 20/10/2011, $23^{\text {a }}$ Vara do Trabalho de Porto Alegre)

"VÍNCULO DE EMPREGO. CATEGORIA PROFISSIONAL. Demonstrada a prestação de serviço nas dependências do Banco Bradesco S.A., com a comercialização dos produtos desta instituição bancária e da Bradesco Vida e Previdência S.A., isso com pessoalidade, subordinação, não eventualidade e mediante remuneração (comissões), preenchidos estão os requisitos do artigo $3^{\circ}$ consolidado. Inaplicável à hipótese o disposto no artigo 17 da Lei n. ${ }^{\circ}$ 4.594/1964, que veda a formação de vínculo de emprego entre o corretor e a empresa seguradora. Portanto, não ocorrida a prestação de serviço autônomo e devidamente comprovada a execução de atividades típicas de bancário, mediante subordinação direta às ordens e ao controle do Banco reclamado. 2. Reconhecida a condição de bancária, a conseqüência lógica é o deferimento de parcelas devidas à categoria profissional, em homenagem ao princípio da primazia da realidade"

(TRT 7 $7^{\mathrm{a}}$ Região/CE - 0108600-0520095070027, Relator: MARIA ROSELI MENDES ALENCAR, Data de Julgamento: 08/06/2011, Primeira Turma, Data de Publicação: 04/07/2011 DEJT)

As três decisões acima elencadas tratam de diferentes formas e configurações da 
subordinação de um trabalhador com uma instituição bancária. A primeira lida com um tema muito recorrente e que se desenvolve a partir de uma lógica produtiva muito comum em bancos: a figura do correspondente bancário. Essa forma de organização produtiva é criada sob o pretexto de levar um benefício ao consumidor, que de fato acaba sendo beneficiado pela extensão dos serviços bancários onde antes não havia uma agência.

Contudo, essa "benesse"concedida ao destinatário dos serviços é feita em detrimento os direitos do trabalhador, na medida em que, na maioria das vezes, o correspondente bancário é um sujeito que, além de exercer as funções de bancário - sem pertencer a categoria profissional e portanto sem as condições benéficas garantidas pelas vantagens auferidas pelas negociações coletivas dos bancários - ainda realiza as funções do estabelecimento em que está inserido.

A figura do corresponde faz com que o banco ofereça seus serviços, aumentando sua carteira de clientes e auferindo lucros, sem sequer assumir os riscos da atividade econômica. Isso porque, se o mercadinho fechar, o banco pode se eximir de qualquer responsabilidade e, ainda por cima, o trabalhador que recebia pagamentos de contas diversas, efetuava depósitos, muitas vezes realizava saques e vendia produtos do banco (como título de capitalização, seguros etc) terá que, caso seus direitos não sejam respeitados, pleitear o recebimento do que lhe foi sonegado do mercadinho falido e não da instituição financeira.

A situação é ainda mais gritante se visualizarmos como a figura do correspondente é vendida pelos bancos. Em uma rápida pesquisa em sites de instituições financeiras ${ }^{103}$ notamos que o serviço é oferecido como uma facilidade para o consumidor e um benefício para o estabelecimento no qual o correspondente se instalará. Não há dúvida que o mercadinho hipoteticamente acima representado atrairá mais clientes para o seu negócio, caso tenha um míni banco ali dentro. Mas não podemos esquecer que o prejuízo social que isso representa é enorme. Assim, nada mais correto que quem trabalhe em um correspondente bancário, bancário seja. Infelizmente quem mais burla direitos trabalhistas

103 A título exemplificativo podemos indicar os seguintes sites:

http://www.itautec.com.br/pt-br/servicos/outsourcing/correspondente-bancario acesso em 05/12/11

http://www.hsbc.com.br/1/2/portal/pt/para-sua-empresa/atendimento/correspondente-bancario acesso em $05 / 12 / 11$ 
com essa modalidade de serviços é o próprio Estado, que deveria garanti-los, tendo em vista que todas as Lotéricas do país funcionam como correspondentes da Caixa Econômica Federal.

As outras duas decisões tratam de uma outra forma de contratação, que é a de colocação de trabalhadores, supostamente autônomos ou vinculados a uma empresa terceira qualquer, para venderem produtos bancários até mesmo dentro de bancos. Sob a alegação de que esses trabalhadores apenas prestam um serviço de comércio - como se eles possuíssem o "know-how de mascates" que o banco não tem - as instituições não lhes conferem a condição de bancário.

A análise da questão sob a ótica da subordinação estrutural, de inserção na dinâmica produtiva e comercial das empresas para as quais o trabalhador efetivamente trabalha, recoloca as coisas no seu devido lugar e propicia o reconhecimento de um vínculo de emprego que, sob a ótica da subordinação jurídica estrita e tradicional talvez não fosse possível de se reconhecer.

“1. RELAÇÃO DE EMPREGO. MONTADOR DE MÓVEIS. SUBORDINAÇÃO ESTRUTURAL Incontroverso o trabalho, firma-se em favor do trabalhador montador de móveis de empresa que tem na comercialização de móveis montados sua atividade-fim, a presunção de que o labor foi realizado de forma subordinada com a inserção do obreiro na estrutura da empresa que se apropriava da sua força de trabalho. A mera exibição de recibo de pagamento por 'prestação de serviço autônomo' não serve para infirmar a presunção de subordinação estrutural do obreiro à empresa, não tendo tal documento o condão de, por si só, demonstrar a autonomia da prestação laboral"

(TRT 24a Região/MS - RO 854200800124007 MS 00854-2008-001-24-00-7 (RO), Relator: FRANCISCO DAS C. LIMA FILHO, Data de Julgamento: 25/03/2009. Data de Publicação: DO/MS N ${ }^{\circ}$ 515 de 02/04/2009)

Chocante, no caso acima, a tentativa da empresa de se desvincular do elemento trabalho. Um estabelecimento que tem por objetivo a comercialização de móveis montados chega ao cúmulo de contratar prestadores de serviço (e até lhes passar recibo, até) “autônomos" para montarem móveis. Não são necessários maiores comentários para além dos que já constam na ementa

Felizmente, o relator do caso aplicou o princípio da primazia da realidade, desconsiderando os recibos de pagamento pela "prestação de serviço autônomo". Ocorre, todavia, que muitas vezes o formalismo acaba por tolher direitos, como é o caso da decisão a seguir. 
"RELAÇÃO DE EMPREGO INEXISTÊNCIA Provado que a reclamante firmou com a reclamada um contrato de arrendamento, mediante o qual desenvolvia sua profissão de manicure de maneira autônoma, não subordinada e utilizando-se de seus próprios produtos e instrumentos, correta a decisão que concluiu pela inexistência de relação de emprego entre as partes"

(TRT 7 Região/CE - RO 0001568-4920105070012, Relator: PAULO RÉGIS MACHADO BOTELHO, Data de Julgamento: 26/09/2011. Data de Publicação: 30/09/2011 DEJT)

Inicialmente cumpre esclarecermos que os comentários feitos aqui são suposições, somente podendo ser confirmados após a análise dos autos do processo em questão. Contudo, é muito difícil crer que uma manicure tenha firmado um "contrato de arrendamento" com um salão de beleza para o desenvolvimento de suas atividades de maneira autônoma.

Só quem não conhece minimamente o funcionamento desses locais pode supor que o contrato de arrendamento entre a manicure e o salão foi celebrado na mais perfeita condição de liberdade contratual, com as partes esclarecidas e cientes do que isso representaria. $\mathrm{O}$ direito do trabalho não pode se prender a essas questões meramente contratuais para fazer ou não incidir suas normas. O fato do trabalhador utilizar seus próprios produtos e ferramentas, por si só, não garante a condição de autonomia que a ementa afirma.

Ainda que nos faltem elementos para saber o que realmente aconteceu no caso em tela, à decisão faltam elementos de fundamentação para concluir pela inexistência da relação de emprego. A decisão a seguir também não reconhece a relação de emprego a partir de uma leitura clássica da subordinação, que deixa o trabalhador à míngua de proteção.

"RELAÇÃO DE EMPREGO. NÃO CONFIGURAÇÃO. VERBAS TRABALHISTAS INDEVIDAS. Considerando que, do conjunto probatório, não se extrai a presença dos elementos fático-jurídicos configuradores da relação de emprego entre reclamante e reclamadas, de forma que o autor prestou serviços de escolta de mercadorias de forma autônoma, sem qualquer subordinação, tem-se por correta a sentença de base que afastou o alegado vínculo empregatício e indeferiu o pagamento das parcelas trabalhistas ao obreiro. Recurso ordinário conhecido e não provido"

(TRT $16{ }^{\text {a }}$ Região/MA - RO 01662-2008-015-16-00-4, Relator: AMÉRICO BEDÊ FREIRE, Data de Julgamento: 18/01/2011, Data de Publicação: 24/01/2011)

O inteiro teor da decisão acima estava disponível para consulta, e integra o Anexo. Ao longo da fundamentação de seu voto, o desembargador relator faz uma explanação sobre a subordinação jurídica, ou a falta dela, do superior hierárquico do reclamante, quem 
contratava e coordenava seus serviços, junto à empresa tomadora. $\mathrm{O}$ relator conclui que em não havendo essa subordinação, ou seja, o dito "chefe da escolta" não sendo empregado da empresa dona das mercadorias escoltadas não poderia contratar empregados para essa empresa.

A leitura é extremamente formal e cria uma relação de causa e consequência que não existe. $\mathrm{O}$ argumento em prol da impossibilidade de reconhecimento do vínculo de emprego do reclamante com a empresa tomadora dos serviços não se sustenta a partir dessa leitura, pois se o fato de quem contrata os serviços de outrem sem ser empregado da empresa tomadora inviabilizasse o reconhecimento do vínculo de emprego entre o prestador de serviços e a empresa que lhe toma esses serviços, nunca poderíamos admitir a nulidade de um contrato de terceirização por exemplo.

É claro que, da leitura do inteiro teor do acórdão, a situação se torna mais complexa. Contudo, ainda que permitida a terceirização dos serviços de vigilância, sequer isso o voto reconhece, na medida em que afirma em certo momento: "Destarte, concluo que, na verdade, o que existia era uma espécie de 'sociedade' entre o Sr. Elias e os demais componentes da equipe de escolta, dentre os quais se inseria o reclamante". O Sr. Elias era o contratante de fato dos serviços do reclamante.

É claro que as conclusões aqui supostas podem estar equivocadas, mas frisamos novamente que é muito difícil de acreditar na versão apresentada pelo relator. Mais do que discutir um caso concreto a partir de uma decisão, mostramos com isso como o elemento da subordinação visto pelo viés estritamente jurídico e objetivo, cria situações, no mínimo, controversas. A solução da inserção da escolta do transporte de mercadorias na estrutura organizacional de uma empresa, inserindo a subordinação estrutural na dinâmica da relação de emprego, colocaria a situação em outro patamar. Talvez no final chegássemos à mesma conclusão do relator, mas já sairíamos de uma situação de proteção. As questões formais de ônus da prova e utilização do processo não podem servir a colocar o trabalhador em uma situação em que ele deve mostrar que merece direitos. A lógica deve ser inversa: ele merece direitos e se na prática ficar comprovada autonomia real e não configuração da relação de emprego, aí sim podemos deixar de aplicar o direito do trabalho. 
A próxima decisão, agora voltando para decisões que aplicam o conceito da subordinação para ampliar as possibilidades de configuração da relação de emprego, vai num sentido bem próximo disso que estamos tratando, do grau máximo da proteção.

"VÍNCULO EMPREGATÍCIO. SUBORDINAÇÃO RETICULAR .CONFIGURAÇÃO. Dá-se a chamada subordinação reticular quando, não obstante o laborista tenha um controle relativo sobre suas funções, de forma supostamente autônoma, não detém a mesma autonomia com relação ao aspecto econômico da atividade empresarial. Na dúvida entre o trabalho dito "autônomo-dependente" e o empregado clássico, a boa regra de hermenêutica aconselha a não reduzir o potencial expansivo e protetivo do direito do trabalho. Nestas condições, com a existência simultânea dos demais elementos caracterizadores da relação de emprego, a saber; onerosidade, pessoalidade e habitualidade, deve-se reconhecer o vínculo empregatício, com a conseqüente descaracterização de outras formas de relação de trabalho. Recurso da ré a que se nega provimento."

(TRT 15 Região/SP - RO 031019/2010, Relator: CARLOS ROBERTO DO AMARAL BARROS, Data de Publicação: 04/06/2010)

Exemplar, a solução dada ao caso. Na dúvida, fiquemos com a proteção. Não podemos baixar a guarda no caráter protetivo do direito do trabalho sob pena de estarmos concordando com a criação de categorias intermediárias de proteção, que logo serão tomadas por regra pelas empresas a fim de contratarem trabalhadores "autônomosdependentes", "desonerarem" o "custo" do trabalho e dividirem os riscos da atividade econômica com o trabalhador.

No caso acima analisado o relator se utiliza do conceito de subordinação reticular, já tratado anteriormente. Nos termos do voto o reclamante "submetia-se a uma forma de subordinação denominada reticular, de natureza estrutural, onde o laborista não podia exercer suas funções sem a atividade empresarial encabeçada pelos reclamados". Ou seja, para a consecução de suas atividades, o trabalhador precisava, necessariamente, da atividade empresarial das empresas rés. Diante disso, nada mais correto que considerá-lo empregado dessas empresas. Essa forma de encarar a subordinação do trabalhador difere um pouco do sentido estritamente estrutural de inserção na atividade econômica, mas mantém o liame estruturante que liga o trabalho ao capital. Sem a organização da produção, via de regra exercida pelo capital, não há como desenvolver um trabalho orientado a um determinado fim econômico que não seja meramente individual.

Outro interessante julgado que adota o mesmo conceito de subordinação reticular é o seguinte.

"RESPONSABILIDADE SUBSIDIÁRIA. SUBORDINAÇÃO RETICULAR OU ESTRUTURAL- 
Não se está aqui a criticar os novos modelos de gestão de produção surgidos através da história industrial, mas sim para tentar assegurar que o capital não se esquive de suas responsabilidades em relação ao trabalhador. Ele - o capital, corporificado na figura da empresa, independentemente da personalidade jurídica que assuma - é o verdadeiro empregador. Seja o labor prestado em suas dependências, seja nas de interpostos, o obreiro é um elo em sua dinâmica produtiva, que, se rompido, faz cessar o ciclo, motivo pelo qual deve a empresa-rede dar-lhe todas condições dignas de sobrevivência. As tomadoras, sob a alegação de redução de custos e de que determinadas atividades não fazem parte de seu portfólio, por não serem "atividades-fim", contratam pessoas físicas ou jurídicas descapitalizadas para a substituírem em determinadas fainas, sem contudo, na maioria das vezes, observar situações tais como econômica, trabalhista, fiscal, etc. de tais prestadores de serviços, seja na assinatura do contrato, seja de maneira periódica como forma de monitoramento de sua solvibilidade. A Subordinação Reticular ou Estrutural está aí para garantir ao obreiro que seus direitos sejam respeitados; para garantir que o capital não transfira os riscos de sua investida àquele que é hipossuficiente na relação havida; está aí para minimizar atos fraudulentos aos direitos trabalhistas, fiscais e previdenciários, atos esses que surgem com os nomes mais pomposos, mas que, na prática, trazem à tona traços de velhas artimanhas utilizadas, inclusive, no século XVIII, mais especificamente em sua primeira metade. A empresa-rede, preocupada com as questões sociais, tem o dever de assumir a responsabilidade subsidiária caso a interposta não possa adimplir com os débitos trabalhistas devidos, motivo pelo qual MANTENHO o decisum de origem. Em casos semelhantes a este é possível, inclusive, reconhecer a subordinação direta com o tomador ou empresa-rede. Ocorre, entretanto, que em homenagem ao Princípio da Proibição do "reformatio in pejus", torna-se inaplicável nestes autos."

(TRT $9^{a}$ Região/Paraná - RO 5371-2009-892-9-0-9, Relator: RICARDO TADEU MARQUES DA FONSECA, 2A. TURMA, Data de Publicação: 03/05/2011)

Ainda que a solução formal acerca da responsabilidade subsidiária da tomadora de serviços, nos casos de terceirização, seja passível de críticas, é interessante notar que nesse julgado o relator enfrenta as questões atuais da re-estruturação produtiva e da empresa em rede, para afirmar que isso não pode nunca representar um retrocesso para os direitos dos trabalhadores. Por trás de tudo, reafirmamos, está a tentativa das empresas de transferir, ou no mínimo compartilhar, os riscos da atividade econômica com o trabalhador. O que não pode ser tolerado.

Por uma questão processual, também discutível, o relator não reconheceu o vínculo de emprego entre o reclamante e a empresa tomadora dos serviços e subsidiariamente responsável pelos débitos trabalhistas, mas foi muito bem colocado que, em casos semelhantes, o vínculo de emprego poderia ser reconhecido diretamente com a dita “empresa-rede". É justamente esse o objetivo dessa nova visão sobre a subordinação: ampliar o leque de possibilidades de reconhecimento de trabalhadores como empregados.

A seguir analisaremos duas situações muito comuns na prática trabalhista, a partir desses novos fundamentos trazidos pela visão da subordinação que estamos afirmando: a questão das cooperativas fraudulentas e a clássica distinção entre autonomia e 
subordinação do representante comercial.

"COOPERATIVA. FRAUDE. RELAÇAO DE EMPREGO COM O TOMAR DOS SERVIÇOS CONFIGURADA. A relação de cooperativismo é uma relação de autonomia e solidariedade. Autonomia do prestador de serviços (quando a cooperativa é dessa espécie) que, como todo autônomo, trabalha quando e como quer, sem imposição de ordens. Solidariedade entre os cooperados, que são trabalhadores que se unem para o alcance, em conjunto,de um objetivo comum. Se a trabalhadora estava subordinada ao gestor da cooperativa, não era, definitivamente, autônoma. E se desenvolvia atividade essencial para a tomadora, é óbvio que as ordens que recebia do gestor nada mais eram do que retransmissão daquelas que este recebia da primeira ré. Configura-se, nesses casos, a "subordinação estrutural", expressão consagrada pela doutrina do Ministro Maurício Godinho, que se caracteriza pela inserção do trabalhador em um módulo de produção (como se fosse uma engrenagem de um mecanismo maior) que o obriga, efetivamente, a trabalhar de uma determinada e precisa forma, ainda que inexistam ordens diretas. Assim como a engrenagem não pode rodar para o lado que deseja, mas tem que acompanhar o movimento geral das demais peças da máquina, a reclamante não podia atuar da forma que queria e isso, por si só, já caracteriza a limitação da vontade, incompatível com a condição de autonomia, típica das verdadeiras relações de cooperativismo."

(TRT2 ${ }^{\mathrm{a}}$ Região/SP - RO 01258-2006-039-02-00-5, Relator: PAULO SÉRGIO JAKUTIS, Data de Julgamento: 11/05/2010, 4ª TURMA, Data de Publicação: 21/05/2010)

"REPRESENTAÇÃO COMERCIAL AUTÔNOMA X VENDEDOR EMPREGADO - TEORIA DA INSERÇÃO OU SUBORDINAÇÃO ESTRUTURAL - VÍNCULO EMPREGATÍCIO CARACTERIZADO. O que distingue o representante comercial do vendedor empregado é exatamente a autonomia com que aquele exerce as suas atividades, o que sempre é revelado por um contexto fático que engloba carteira própria de clientela, não exigência do representado de metas de vendas, liberdade de abrir cadastros de novos e excluir clientes, dever de prestar contas, receber apenas orientação do representado, sem, contudo, acompanhamento de supervisor etc. Enfim, um conjunto de circunstâncias que revelam ter o representante comercial uma clientela própria para oferecer ao representado, em prol de quem efetuará negócios comerciais. Na hipótese, à míngua de prova segura que à recorrente competia produzir, resta evidenciada a existência de plena subordinação jurídica, elemento diferenciador entre o representante comercial autônomo e o vendedor regido pela CLT, haja vista que em ambos os contratos se encontram presentes os requisitos da pessoalidade, não-eventualidade e onerosidade. É a chamada "subordinação estrutural", conforme classificação nova que na doutrina de Lamarca era a inserção da atividade do trabalhador nos objetivos sociais da empresa. Neste contexto, indubitável que a prestação de serviços dava-se de forma subordinada, com os demais elementos dos artigos $2^{\circ}$ e $3^{\circ}$ da CLT. Recurso da ré desprovido."

(TRT 15a Região/SP - RO 069044/2011, Relator: JOSÉ ANTONIO PANCOTTI, Data de Publicação: $14 / 10 / 2011)$

A primeira decisão usa o conceito de subordinação estrutural para descaracterizar a condição de cooperada da reclamante e considerá-la efetivamente empregada da cooperativa reclamada. A questão das cooperativas tornou-se um verdadeiro problema social nos últimos tempos.

Por detrás de organizações que supostamente se inspiram em conceitos do cooperativismo - que se baseia fundamentalmente na solidariedade entre os cooperados muitas entidades fraudam direitos trabalhistas, contratando empregados como se cooperados fossem ou, ainda, servindo de verdadeiras empresas de interposição de mão- 
de-obra. Essa forma de organização foi apropriada pelo capital, que viu mais uma maneira de utilizar serviços de empregados sem a contrapartida social do direito do trabalho.

À luz da antiga teoria da subordinação jurídica, muitas cooperativas já vinham sendo declaradas fraudulentas pela justiça, que reconhecia o vínculo de emprego de seus "cooperados". Com a teoria da subordinação estrutural, fecha-se o cerco ainda mais em torno dessas organizações. Passa a ser menos importante a autonomia do trabalhador e dáse mais força à sua inserção na atividade econômica, o que por si só já tem o poder de demonstrar o verdadeiro caráter da cooperativa, tendo em vista que uma verdadeira cooperativa tem por objetivo o fomento econômico das atividades de seus próprios cooperados, ao passo que, se a cooperativa funciona como uma empresa - exercendo atividade empresarial em benefício de um restrito grupo, ou de outras empresas - sua finalidade precípua do cooperativismo já se mostra viciada e temos um indício de fraude.

A teoria da subordinação estrutural, portanto, pode ser usada para a identificação indireta de fraudes já que, para a sua aplicação a própria atividade econômica deve ser analisada, abrindo os horizontes do direito para além da simples dicotomia entre autonomia e subordinação.

A segunda decisão trata da clássica questão da autonomia do representante comercial. A ementa se utiliza do que podemos identificar com o conceito de subordinação integrativa já exposto anteriormente. Ainda que o relator use a expressão "subordinação estrutural", parece-nos mais razoável que o que foi auferido no caso concreto era a ausência de traços de autonomia na execução do trabalho do reclamante, coadunando-se assim com a teoria da subordinação integrativa.

Como a atividade do autor da ação integrava as atividades da empresa ré e não apresentava as características de um autônomo, como efetivamente são os representantes comerciais, o relator achou por bem considerá-lo subordinado e manter a decisão de primeira instância que reconheceu o vínculo empregatício do autor.

As decisões analisadas revelam um movimento da jurisprudência no sentido do alargamento do conceito de subordinação a fim de ampliar as hipóteses de vínculo de emprego e estender a proteção trabalhista a trabalhadores que não seriam considerados 
empregados pela visão clássica da subordinação jurídica. Ao longo da análise e comentários da jurisprudência selecionada, escolhemos duas decisões que não reconhecem o vínculo de emprego de trabalhadores reclamantes a partir de uma visão restrita da subordinação.

Essas decisões foram escolhidas justamente para demonstrar como uma visão que não amplia os horizontes do direito do trabalho pode ser prejudicial ao trabalhador. É claro que mantemos a ressalva de não podermos fazer uma análise completa dessas decisões, na medida em que não conhecemos tudo o que consta dos autos daquelas ações, mas exemplificativamente pudemos tomar contato com uma linha jurisprudencial que, infelizmente, ainda é muito grande e não interpreta os ditames sociais do direito do trabalho a favor do trabalhador.

Reafirmamos que as posições acerca da proteção trabalhista estão em disputa, nos colocando ao lado dos que interpretam o direito no sentido da ampliação de direitos e garantis e do não retrocesso. Por fim, terminamos com uma decisão que alia a teoria dos direitos sociais à prática trabalhista. A decisão é do magistrado Jorge Luiz Souto Maior, já citado anteriormente na condição de teórico do direito do trabalho. Ao fazer de sua atividade judicante um momento privilegiado de aplicação das teorias do direito do trabalho em prol da justiça social e da melhoria das condições do trabalhador, Souto Maior dá uma contribuição decisiva para a disputa em torno da formulação do direito que tanto defendemos.

"SUPERSUBORDINAÇÃO. DANO PESSOAL. NÃO PAGAMENTO DE SALÁRIOS E DE VERBAS RESCIÓRIAS. INDENIZAÇÃO DEVIDA. Ao ser forçado a deixar o emprego, por não ter recebido salário, e sequer receber as verbas rescisórias, o reclamante foi vítima duas vezes de dano à sua pessoa, pois o desrespeito deliberado e inescusável de direitos trabalhistas conduz o trabalhador a uma condição de sub-cidadania, já que o Direito do Trabalho, conforme expressa o Min. Maurício Godinho, é o marco regulatório mínimo da cidadania (ou o patamar mínimo civilizatório). Não cumprir direitos trabalhistas de forma grosseira, intencional, portanto, não é mero "inadimplemento contratual". Trata-se, isto sim, de uma agressão ao cidadão trabalhador e, porque não dizer, a toda a sociedade. O Direito do Trabalho é o retorno de natureza sócio-econômica que se confere ao trabalhador para que este venda a sua força de trabalho ao modelo de produção capitalista. No contexto do Estado Social Democrata, mantendo-se a lógica capitalista, a exploração do trabalho, que não deixa de existir, é amenizada, atraindo um aspecto de harmonização de interesses, em razão da concessão de garantias trabalhistas e sociais. Assim, se há uma relação de trabalho, na qual o trabalho alheio é utilizado para o desenvolvimento de um projeto de acumulação de capital, sem o efetivo respeito aos direitos sociais (que servem, muitos deles, à preservação da saúde e para o convívio social e familiar), quebra-se o vínculo básico de uma sociedade sob a égide do Estado de Direito Social. O dado da exploração é o único que sobressai. É a exploração pela exploração, nada mais. A compensação de natureza social não 
existindo gera, portanto, uma super-exploração. Juridicamente falando, a subordinação se potencializa, fazendo surgir, então, a figura da supersubordinação. O supersubordinado, por definição, é o trabalhador, ser humano, reduzido à condição de força de trabalho, já que desrespeitados, deliberadamente e como estratégia econômica, seus direitos fundamentais. O salário, como todos sabem, destina-se a suprir necessidades vitais básicas do ser humano e as verbas rescisórias ainda mais, sobretudo considerando a condição de desempregado que o trabalhador passa a ostentar. Qualquer pessoa de mediana inteligência e que tenha a capacidade de se colocar no lugar do outro, que também é um cidadão, saberá compreender os problemas pessoais (de natureza patrimonial e extrapatrimonial) sofridos por alguém, que tem na venda da força de trabalho a sua única fonte de sobrevivência e de inserção social, ao não receber em dia o seu salário e quando perde o emprego e, pior ainda, quando isso se dá sem sequer o pagamento das verbas rescisórias.

(TRT $15^{\text {a }}$ Região/SP - RO 041671/2009, Relator: JORGE LUIZ SOUTO MAIOR, Data de Publicação: 17/07/2009)

Ao invés de simplesmente comentarmos a decisão acima, preferimos deixá-la para reflexão. $\mathrm{O}$ ineditismo de seus conceitos e da forma de colocação do problema no direito do trabalho reforça a nossa tese de que há atuação possível dentro do direito que rompa com uma visão reducionista, solene e excessivamente dogmática. A criação, reformulação e, até mesmo, destruição de conceitos deve acontecer com mais frequência no direito para que possamos ter a exata dimensão de realidade que uma atuação crítica e comprometida necessita.

Dessa maneira, a releitura do conceito jurídico de subordinação exerce um importante papel nesse contexto, pois se não repensarmos a forma do enquadramento jurídico de determinados fenômenos sociais, e deixarmos conceitos estanques parados no tempo, estaremos defasados historicamente ou, o que é pior, estaremos coadunando com novas práticas de burla a direitos. 


\section{VII - CONCLUSÃO}

Desmitificar conceitos, abandonando o mito da complexidade e tornando-os simples e de fácil compreensão, é uma das tarefa do um jurista crítico e comprometido com a mudança social. Apesar da identificação do conceito de subordinação com exploração do trabalho não ser algo simples - até porque senão toda a explanação até aqui proposta perderia sentido, sendo mera forma em detrimento de algum conteúdo procuramos tratá-lo de maneira clara e direta, na medida em que a complexificação de realidades serve aos interesses de quem acha tudo tão complexo a ponto de não se poder modificar.

Confrontando autores, professores, palestrantes, magistrados, procuradores e advogados que militam em prol de um encastelamento do direito do trabalho, percebemos que um direito do trabalho "cada vez mais complexo" se afasta da realidade do trabalho objeto e destino da norma.

Tais pensamentos, por exemplo, tendem a afirmar a falácia de que atualmente, na sua caracterização clássica fordista, não existem mais emprego ou empregados, concluindo que o direito do trabalho deve se voltar a grupos de trabalhadores autônomos, que não possuem proteção trabalhista, para fazer incidir normas de caráter protetivo. Ressaltam, todavia, que a proteção deve ser "diferida", e não a mesma conferida aos antigos empregados, pois esses novos trabalhadores já não são tão hipossuficientes. Por outro lado, afirmam que existem trabalhadores que não são tão autônomos assim, mas que também não são exatamente subordinados da maneira clássica. Estes que devem ter a regulação do direito do trabalho de uma terceira maneira, maior do que a dos autônomos mas menor do que a daqueles empregados que não existem mais: a chamada proteção "modulada", que deve enfrentar os problemas casuisticamente. O direito do trabalho regula a atividade econômica? Mas quem disse isso? A proteção modulada, argumentam, é fundamental para enfrentarmos as condição de crise de um mundo cada vez mais complexo. E, aliado a isso, solucionam todo o direito social, criando a flexiseguridade, um excelente instrumento de enfrentamento da condições complexas de crise do trabalho. E o emprego? O emprego acabou...simples, quer dizer, complexamente assim.

Tal coisa é muito complexa, não vamos discutir. Aquela outra também é muito 
difícil. Aquela terceira, nem pensar. E assim, abandonam-se discussões muito necessárias que, ainda que não tão simples assim, possuem conceitos, classificações, modelos e esquemas definidos, que permanecerão imutáveis se não forem questionados. Percebe-se, assim, como o argumento do complexo muitas vezes se sobrepõe à própria materialidade do conceito.

Ocorre que os que se utilizam do argumento do complexo, na maioria das vezes, não deixam de enfrentar as questões, mas apenas fazem de outra maneira, ora simplesmente afirmando o status quo, ora querendo mudanças para pior - no nosso caso, para a desregulamentação, a diminuição da proteção, a afirmação da livre contratação de mão de obra, e assim por diante.

Buscamos enfrentar uma questão tida por muito complexa: a subordinação objetiva ou não, jurídica ou não - do empregado ao empregador. Muitas teorias foram criadas e afirmadas para darem conta da complexidade desse fenômeno e da sua inserção no mundo do direito. Essas teorias, muitas vezes, colocam a subordinação jurídica como algo ainda mais difícil de ser entendido do que a própria subordinação do trabalho ao capital. Ora, se a exploração do trabalho - sua subsunção ao capital - é a base de toda a criação do fenômeno jurídico da subordinação, como esse conceito pode ganhar vida própria e teorias intrincadas, que muitas vezes obscurecem sua própria base? As respostas são múltiplas, mas todas passam pelo enebriamento da exploração. As teorias jurídicas da subordinação nada mais fazem do que retirar o caráter de explorado do trabalho para o lançar em um novo patamar, o do trabalho juridicamente subordinado - sendo que uma coisa não exclui a outra, e nem poderia.

Tiramos o foco da exploração, perdendo-nos em teorias de conceituação de uma subordinação jurídica que apaga todo seu lastro material. Dessa maneira, não conseguimos enxergar que uma realidade está completamente imbricada na outra. Considerar o trabalho subordinado e o trabalho explorado como conceitos próximos ou similares, todavia, não dá conta de toda a nossa análise.

Identificar a subordinação com a exploração do trabalho não implica que sempre que houver trabalho explorado teremos, trabalho subordinado e, consequentemente, uma 
relação de emprego. Pela lógica do capitalismo, todo o trabalho que produz mercadoria e gera valor está sendo explorado. Um representante comercial, efetivamente autônomo, está tendo o seu trabalho explorado, ainda que não seja empregado. Para fazer essa distinção, nesse momento, devemos levar em conta o elemento realmente estrutural nessa relação: a organização e exploração do trabalho de maneira coordenada, orientada para um fim específico de consecução de determinada atividade econômica, produção de mercadorias e geração de lucro.

A forma como iremos delimitar os padrões de incidência do direito do trabalho é modificada quando lançamos esse olhar estruturante sobre o conceito jurídico de subordinação e, por conseguinte, sobre a configuração dentro do direito da relação de emprego. Sob a égide clássica e tradicional das molduras de validade, incidência e eficácia do direito trabalhista, cunhou-se um conceito de subordinação jurídica que estava intimamente ligado a outro conceito jurídico: o do poder de direção do empregador.

O empregador do século XX era, por excelência, a empresa fordista. Podemos até imaginar, e é até um clichê, a figura daquele capataz portando um cronômetro e direcionando todo o trabalho da linha de montagem. Hoje as coisas mudaram, ao menos no plano simbólico. Como tratamos, os padrões de exploração se mantém e as mudanças formais da extração de valor do trabalho humano não foram capazes de modificar materialmente o quadro da exploração, ao contrária aprofundaram-no. Dessa maneira, para continuarmos podendo definir empregados e não empregados temos que voltar a definir empregador.

Assim como a definição clássica do empregador fordista também veio "de fora" do direito do trabalho e, até mesmo, do próprio direito, a tarefa de resignificação do conceito de empregador rompe necessariamente com os limites meramente formais do direito do trabalho. É um erro naturalizarmos os conceitos como se eles sempre tivessem existido, fazendo girar sozinha a roda do direito trabalhista, sem interferências externas em perfeita harmonia com o direito e seus conceitos, regras, princípios, fundamentos e valores. Como já afirmamos, a contratação de mão-de-obra na forma de emprego é mais uma necessidade do capital do que propriamente uma estrutura de proteção criada pelo direito. $\mathrm{O}$ direito do trabalho, a partir de uma situação concreta, moldou uma ferramenta de regulação das 
relações de trabalho que, a custo de muita disputa, assumiu um caráter protetivo e que pode, também pela disputa, perder esse caráter.

É necessário voltarmos a pensar no conceito jurídico de empregador, lançando nossa visão de análise para elementos econômicos e sociais que determinam como alguém - assumindo os riscos da atividade econômica - irá coordenar a execução do trabalho e contratar trabalhadores para exercerem determinada atividade de maneira organizada.

E essa resignificação não passa, necessariamente, pela mudança de estruturas legais. Precisamos identificar as situações em que há organização da atividade econômica com a contratação de mão-de-obra para exercer atividades de maneira coordenada, com o investimento de capital sendo feito por uma das partes que irá assumir o risco da atividade e ficará com os bônus da produção. Identificando essa figura como o empregador, podemos afirmar que a mão-de-obra contratada trata-se de empregado.

Dessa forma, todo trabalhador que compete para a consecução da atividade econômica de outrem - não se beneficiando dos bônus da produção recebendo uma mais ou menos quantia fixa pelo seu trabalho, participando de uma estrutura de coordenação e orientação finalística da atividade produtiva e gerando lucro para o tomador de seu serviço deve ser considerado subordinado e, portanto, empregado.

Esse conceito, apesar de não ser um conceito pronto e acabado, representa uma modificação da forma jurídica. Modificação esta que não altera nem rompe com a própria estrutura formal do direito, mas que cria campos de disputa que podem e devem ser apoderados pela classe trabalhadora. Assim, temos uma nova forma de interação do direito com o trabalho, que acaba por influenciar até mesmo a maneira como os indivíduos que pensam e atuam no direito do trabalho lidam com a realidade social. A partir de uma nova visão dos direitos sociais, conseguimos criar mecanismos mais democráticos, e orientados para o fim da justiça social, de regulamentação da atividade produtiva.

Confrontar o direito com a realidade social, criando maneiras de interação material entre as estruturas jurídicas e o mundo fático que por elas é regulado, estabelece um novo patamar para a atuação daqueles que estão comprometidos com a mudança. Evitar esses "choques de realidade", todavia, faz com que tudo permaneça como está ou, ainda pior, 
seja modificado não para atender aos interesses dos trabalhadores. A mudança econômica e social somente será possível quando o direito não servir como freio aos movimentos populares ou como instrumento de dominação, permitindo proposições como as que aqui apresentamos.

Abrir o direito do trabalho para além da dogmática é proporcionar a utilização das estruturas jurídicas em prol da valorização do trabalho, e não apenas de sua exploração. Colocadas as questões de maneira clara e direta, sem os subterfúgios da mistificação da complexidade, podemos criar um espaço público de debate. Contudo, a maior tarefa, da politica, ainda está a ser enfrentada.

Não podemos negar que vivemos um momento privilegiado para a formulação política., na medida em que o capitalismo está em crise e a tendência é que suas estruturas sejam modificadas para a manutenção do modo de produção. Contudo, nesses momentos históricos, o avanço das políticas de manutenção da ordem produtiva é pautado pela organização das forças contrárias ao sistema. A simples organização, contudo, não basta: é preciso que ela seja acompanhada de programas, proposições e orientações práticas sobre o que fazer para enfrentar a crise, na contramão das propostas de manutenção da ordem e da exploração. E é apenas com pensamento crítico que podemos nos situar de maneira verdadeiramente comprometida no campo dessa disputa.

Sabe-se que o campo dos direitos sociais - especificamente o do direito do trabalho - é o mais atacado pelas forças conservadoras. E, em tempos de crise, esses ataques tendem a ter sua força destruidora das garantias sociais dos trabalhadores recrudescida. Nesse sentido, é fundamental formularmos respostas fundamentadas e suficientemente sólidas para que possamos, não apenas defender o direito do trabalho desses ataques, mas também avançar. E avançar significa fazer o que nos propusemos nesse estudo: propor uma leitura estrutural do direito do trabalho que beneficie a classe trabalhadora. Por ora, focamos no conceito dogmático da subordinação, mas a leitura que fizemos do direito pode e deve ser aproveitada para o dimensionamento e resignificação de outros institutos, norteando inclusive a nossa atuação no campo do direito. Essa é a nossa proposta e nossa tarefa. 


\section{BIBLIOGRAFIA}

ANDRADE, Abel. A vida do direito civil: opúsculo I. Coimbra: Imprensa da universidade, 1898.

ANTUNES, Ricardo. (org.) A Dialética do Trabalho: Escritos de Marx e Engels. São Paulo: Expressão Popular. O caracol e sua concha: ensaios sobre a nova morfologia do trabalho. São Paulo: Boitempo, 2005. . Riqueza e Miséria do Trabalho no Brasil. São Paulo: Boitempo Editorial, 2006. . Os sentidos do Trabalho. São Paulo: Boitempo Editorial, 2005. .Adeus ao Trabalho?: Ensaio sobre as Metamorfoses e a Centralidade do Mundo do Trabalho. São Paulo: Cortez/Unicamp. 1995.

ARIENTE, Eduardo Altomare (coor.). Fronteiras do Direito Contemporâneo. São Paulo: Casa Vida. Diretório Acadêmico João Mendes Jr. p. 57-73, 2002.

BERNARDO, Marcia Hespanhol. Trabalho duro, discurso flexível: uma análise das contradições do toyotismo a partir da vivência de trabalhadores. São Paulo: Expressão Popular, 2009.

BERTOLIN, Patrícia Tuma Martins. A economia globalizada e seus efeitos sobre o Trabalho in:

BRAVERMAN, Harry. Trabalho e capital monopolista: A Degradação do Trabalho no Século XX. Trad. de Nathanael C. Caixeiro. $3^{\mathrm{a}}$ ed. Rio de Janeiro: Guanabara. 1974.

CATHARINO, José Martins. Contrato de Emprego. Guanabara: Edições Trabalhistas, 1965.

CESARINO JUNIOR, Antônio Ferreira. Direito Social. São Paulo: EDUSP/LTr. 1980.

CHAUÍ, Marilena. Convite à filosofia. 13 $3^{\mathrm{a}}$ ed. $3^{\mathrm{a}}$ reimpressão. São Paulo: Ática, 2005. 
CIMABALI, Enrico. A nova phase do Direito civil em suas relações econômicas e sociaes. Rio de Janeiro: Livraria Clássica. 1900.

CORREIA, Marcus Orione Gonçalves (org.). Curso de Direito do Trabalho. Volume 1. São Paulo: LTr, 2007.

DEJOURS, Christophe. A banalização da injutiça social. Trad. Luiz Alberto Monjardim. Rio de Janeiro: Editora Fundação Getúlio Vargas, 1999.

DELGADO, Mauricio Godinho . Curso de Direito do Trabalho. 5 ed. São Paulo: LTr. 2006.

DRUCK. Graça e FRANCO, Tânia (org.). A perda da razão social do trabalho: terceirização e precarização. São Paulo: Boitempo, 2007.

FERRAZ JR., Tercio Sampaio Ferraz. Introdução ao estudo do direito: técnica, decisão e dominação. $4^{\text {a }}$ ed. São Paulo: Atlas, 2003.

IANNI, Octavio (org.). Florestan Fernandes: sociologia crítica e militante. São Paulo: Expressão Popular. 2004.

KELSEN, Hans, Teoria Pura do Direito. São Paulo: Martins Fontes, 2003.

MAGANO, Octavio Bueno. Manual de Direito do Trabalho. Vols. I e II. São Paulo: LTr, 1993.

MAIOR, Jorge Luiz Souto. O direito do Trabalho como instrumento de Justiça Social. São Paulo: LTr, 2000.

. Curso de Direito do Trabalho: A relação de emprego, vol. II. São Paulo:

LTr, 2008

. Relação de Emprego \& Direito do Trabalho: no contexto da ampliação da competência da justiça do trabalho. São Paulo: LTr, 2007.

MARX, Karl. O capital: crítica da economia política. Tradução de Régis Barbosa e Flávio R. Kothe. $3^{\text {a }}$ ed. São Paulo: Nova Cultural, 1988. 
. Manuscritos Econômico-filosóficos. Tradução de Jesus Ranieri. $3^{\mathrm{a}}$ reimpressão. São Paulo: Boitempo, 2009.

. Contribuição à crítica da economia política. Trad. e introd. de Florestan Fernandes. $2^{\mathrm{a}}$ ed. São Paulo: Expressão Popular, 2008.

MORAES, Evaristo de. Apontamentos de Direito Operário. 4ª ed. São Paulo: LTr, 1998.

MORAES FILHO, Evaristo. Tratado elementar de Direito do Trabalho. $2^{\mathrm{a}}$ ed. Rio de Janeiro: Freitas Bastos, 1965.

NASCIMENTO, Amauri Mascaro. Curso de Direito do Trabalho. $14^{\mathrm{a}}$ ed. São Paulo: Saraiva, 1997.

NASSIF, Elaine Noronha. Fundamentos da Flexibilização: uma análise de paradigmas e paradoxos do direito e do processo do trabalho. São Paulo: LTr. 2001.

NAVES, Márcio Bilharinho. Marxismo e direito: um estudo sobre Pachukanis. São Paulo: Boitempo, 2008.

ORGANISTA, José Henrique Carvalho. O debate sobre a centralidade do trabalho. $1^{\text {a }}$ ed. São Paulo: Expressão Popular, 2006.

PASUKANIS, Evgeny Bronislanovi. A Teoria Geral do Direito e o Marxismo. Trad. Paulo Bessa. Rio de Janeiro: Renovar, 1989.

PINTO, Geraldo Augusto. A organização do trabalho no século 20: taylorismo, fordismo e toyotismo. São Paulo: Expressão Popular, 2007.

PRADO, Antonio. A controvérsia da crise do fordismo e a transição pós-fordista: algumas reflexões sobre o caso brasileiro in: Emprego e desenvolvimento tecnológico processos de integração regional. São Paulo: DIEESE, 1999.

RENAULT, Luiz Otávio Linhares (et al.). Parassubordinação: em homenagem ao Professor Màrcio Túlio Viana. São Paulo: LTr, 2011.

RODRIGUEZ, Américo Plá. Curso de Direito do Trabalho. São Paulo: LTr, 1982. 
RUSSOMANO, Mozart Victor. Curso de Direito do Trabalho. 6 a ed. Curitiba: Juruá, 1997. SANSEVERINO, Luisa Riva. Curso de Direito do Trabalho. São Paulo: LTr, 1976.

SILVA, Otavio Pinto e. Subordinação Autonomia e Parassubordinação nas Relações de Trabalho. São Paulo: LTr. 2004.

SILVA, Walküre Lopes Ribeiro da. Revisão dogmática da subordinação diante das transformações do mercado de trabalho. Revista do Advogado. São Paulo. V. 26. n. 88. p. 83-99, jul.2006.

SÜSSEKIND, Arnaldo. Curso de Direito do Trabalho. $2^{\mathrm{a}}$. ed. Revista e atualizada. Rio de Janeiro: Renovar, 2004.

VIANA, Marcio Túlio, Terceirização e sindicato: um enfoque para além do jurídico in Revista LTr: legislação do trabalho. São Paulo, ano 67, no 7, pp. 789-790. jul. 2003.

VILHENA, Paulo Emílio Ribeiro de. Relação de emprego: Estrutura Legal e supostos. 2a ed. São Paulo: Saraiva, 1999.

Sites consultados:

http://www.itautec.com.br/pt-br/servicos/outsourcing/correspondente-bancario acesso em $05 / 12 / 11$

http://www.hsbc.com.br/1/2/portal/pt/para-sua-empresa/atendimento/correspondentebancario acesso em 05/12/11

http://exame.abril.com.br/negocios/empresas/noticias/zara-diz-que-desconhecia-trabalhoescravo-em-suas acesso em 17/11/2011

http://www.estadao.com.br/noticias/geral,apos-acusacoes-zara-cria-disque-denuncia-detrabalho-escravo,772606,0.htm acesso em 17/11/2011.

http://www.reporterbrasil.org.br/exibe.php?id=1925 acesso em 17/11/2011

http://www.estadao.com.br/noticias/vidae,fflch-suspende-aulas-por-falta-de-limpeza-nausp, 704884,0.htm Acesso em 27/10/11 


\begin{abstract}
ANEXO
Inteiro teor, quando disponíveis para consulta, dos Acórdãos utilizados no Capítulo
\end{abstract} VI da presente dissertação.

\author{
PROCESSO No ${ }^{\circ}$ TST-RR-424-05.2010.5.18.0054 \\ A C Ó R D ̃̃ O \\ (Ac. $3^{\text {a }}$ Turma) \\ GMALB/mal/abn/mki \\ PE
}

RECURSO DE REVISTA. VÍNCULO
DE EMPREGO. EMPRESA DE
TELECOMUNICAÇÃO.
TERCEIRIZAÇÃO DE ATIVIDADE-

FIM. 1.1. "Serviço de telecomunicações é o conjunto de atividades que possibilita a oferta de telecomunicações", por intermédio de "transmissão, emissão ou recepção, por fio, radioeletricidade, meios ópticos ou qualquer outro processo eletromagnético, de símbolos, caracteres, sinais, escritos, imagens, sons ou informações de qualquer natureza" (art. 60, “caput" e $\S 1^{\circ}$, da Lei $n^{\circ}$ 9.472/97). 1.2. Os serviços de telecomunicações vinculados à implantação e manutenção de redes de acesso, equipamentos e sistemas de telecomunicações estão inseridos nas atividades essenciais das empresas concessionárias dos serviços de telecomunicações, circunstância que desautoriza a prática da terceirização. 1.3. $\mathrm{O} \S 1^{\circ}$ do art. 25 da Lei $n^{\circ} 8.987 / 95$, bem como o inciso II do art. 94 da Lei $\mathrm{n}^{\circ}$ 9.472/97 autorizam as empresas de telecomunicações a terceirizar as atividades-meio, não se enquadrando em tal categoria os instaladores de redes, eis que aproveitados em atividade essencial para $\mathrm{o}$ funcionamento das empresas. 1.4. Rememore-se que o conceito de subordinação deve ser examinado à luz da inserção do trabalhador na dinâmica do 
tomador de serviços, configurando a denominada subordinação estrutural, teoria que se adianta como solução para os casos em que o conceito clássico de subordinação se apresenta inócuo. Recurso de revista conhecido e provido.

Vistos, relatados e discutidos estes autos de Recurso de Revista $\mathrm{n}^{\circ}$ TST-RR-424-05.2010.5.18.0054, em que é Recorrente MARCOS FERNANDO DA CRUZ e Recorridas DOCATEL TELECOMUNICAÇÕES LTDA., ALCATEL LUCENT BRASIL S.A. e BRASIL TELECOM S.A.

O Eg. Tribunal Regional do Trabalho da $18^{\mathrm{a}}$ Região, por meio do acórdão de fls. 576/597, complementado a fls. 615/617, negou provimento ao recurso ordinário obreiro, mantendo a sentença pela qual julgado improcedente o pedido de reconhecimento de vínculo empregatício com a Brasil Telecom.

Recorre de revista o Reclamante, pelas razões de fls. 620/655, com esteio nas alíneas "a" e "c" do art. 896 da CLT.

Admitido o apelo pelo despacho de fls. 661/662.

Contrarrazões a fls. 665/671 e 674/688.

Os autos não foram remetidos ao D. Ministério Público do Trabalho.

É o relatório.

\section{$\underline{\mathbf{V}} \underline{\mathbf{T}} \underline{\mathbf{O}}$}

Tempestivo o apelo (fls. 618 e 620), regular a representação (fl. 13) e dispensado o preparo (fl. 468) estão preenchidos os pressupostos genéricos de admissibilidade.

\section{1 - VÍNCULO DE EMPREGO.}

\section{1 - CONHECIMENTO.}

O Regional, após transcrever o voto do Relator originário, por maioria, negou provimento ao recurso ordinário do obreiro, mantendo a sentença pela qual não reconhecido o vínculo empregatício com a Brasil Telecom, pelos seguintes fundamentos (fls. 589/589-v): 
"Com efeito, nada obstante o judicioso voto, há um detalhe que não pode passar despercebido. Reporto-me ao art. 94, inciso II, da Lei $\mathrm{n}^{\circ}$ 9.472/97 (Lei Geral das Telecomunicações), que legitima a terceirização de serviços na respectiva área, sem restringir à atividade-meio ou à atividadefim.

Por conseguinte, se é legal a terceirização de serviços na área de telecomunicações, não se pode reputar fraudulentos os contratos celebrados pela BRASIL TELECOM S/A com empresas do ramo.

Reitero que em nenhum momento a referida lei prevê terceirização somente em atividade-meio.

Diante do cenário apresentado, verifico que o caso sub judice trata-se de hipótese de terceirização licita, de acordo com o disposto na lei acima referida.

Nesse diapasão, a situação em comento atrai a incidência do disposto no item IV do verbete sumular $n^{\circ} 331$ do Colendo TST, que assim preceitua:

"IV - O inadimplemento das obrigações trabalhistas, por parte do empregador, implica a responsabilidade subsidiária do tomador dos serviços, quanto àquelas obrigações, inclusive quanto aos órgãos da administração direta, das autarquias, das fundações públicas, das empresas públicas e das sociedades de economia mista, desde que hajam participado da relação processual e constem também do titulo executivo judicial (art. 71 da Lei n ${ }^{\circ}$.666, de 21.06.1993)."

Em resumo, se a terceirização é legal, não há falar em sua ilicitude.

Logo, não prospera a pretensão recursal de ver a $1^{\mathrm{a}}$ reclamada, Brasil Telecom S/A, condenada de forma solidária ao pagamento das verbas deferidas judicialmente, impondo-se a manutenção do julgado originário, por escorreito.

Nesse passo, fica mantida a prescrição bienal declarada pelo MM. Juiz a quo em relação ao contrato de trabalho mantido 
com a empresa DOCATEL, bem como o reconhecimento da responsabilidade subsidiária da $1^{\mathrm{a}}$ reclamada, Brasil Telecom S/A.

São indevidas as seguintes parcelas postuladas com fundamento na existência de vinculo de emprego diretamente com a BRASIL TELECOM: salários reajustados pelos índices legais e convencionais; férias $+1 / 3$; adicional por tempo de serviço; produtividade; depósitos do FGTS; ajuda-alimentação; diárias; AC-DRT; gratificação especial; abonos especiais e indenizatório; participação nos lucros e resultados; adicional de sobreaviso; adicional de horas extras; e auxilio-transporte.

Nego provimento, no particular."

Buscando o reconhecimento do vínculo empregatício com a primeira Reclamada, alega o Reclamante que a Lei $n^{\circ}$ 9.472/97 não tem o condão de elidir a relação de emprego que se forma com a empresa tomadora de serviços, no caso da função de manutenção de rede, operação, instalação e mudança de acessos de telecomunicações e de acessórios, uma vez que se trate de sua atividade-fim. Indica violação dos arts. $1^{\circ}$, IV , 7 ${ }^{\circ}$, XXX, XXXI, e XXXII, 170 e 193 da Constituição Federal e contrariedade à atual Súmula 331, I, do TST. Colaciona arestos.

É fato incontroverso que o Reclamante foi contratado pela segunda Ré para prestar serviços de instalação e reparação de linhas e equipamentos de telecomunicações, junto à primeira Reclamada (fl. 587/587-v).

A teor da Súmula 331, I, do TST, a contratação de trabalhadores por empresa interposta é ilegal, formando-se o vínculo diretamente com o tomador dos serviços.

$\mathrm{O}$ "serviço de telecomunicações é o conjunto de atividades que possibilita a oferta de telecomunicações", por intermédio de "transmissão, emissão ou recepção, por fio, radioeletricidade, meios ópticos ou qualquer outro processo eletromagnético, de símbolos, caracteres, sinais, escritos, imagens, sons ou informações de qualquer natureza" (art. 60, $\S 1^{\circ}$, da Lei ${ }^{\circ}$ 9.472/97).

Já o $\S 1^{\circ}$ do art. 25 da Lei $n^{\circ} 8.987 / 95$, bem como o inciso II do art. 94 da Lei $n^{\circ}$ 9.472/97 autorizam as empresas de telecomunicações a terceirizar as atividades-meio (respeitados os limites da Súmula $\mathrm{n}^{\mathrm{o}}$ 331, III, do TST), não se enquadrando em tal categoria os técnicos em telefonia, eis que aproveitados em funções essenciais para o funcionamento da empresa. 
Os referidos dispositivos estão assim redigidos:

“Art. 25. Incumbe à concessionária a execução do serviço concedido, cabendo-lhe responder por todos os prejuízos causados ao poder concedente, aos usuários ou a terceiros, sem que a fiscalização exercida pelo órgão competente exclua ou atenue essa responsabilidade.

$\S 1^{\circ}$ Sem prejuízo da responsabilidade a que se refere este artigo, a concessionária poderá contratar com terceiros o desenvolvimento de atividades inerentes, acessórias ou complementares ao serviço concedido, bem como a implementação de projetos associados.

Art. 94. No cumprimento de seus deveres, a concessionária poderá, observadas as condições e limites estabelecidos pela Agência:

$[\ldots]$

II - contratar com terceiros o desenvolvimento de atividades inerentes, acessórias ou complementares ao serviço, bem como a implementação de projetos associados."

Portanto, ao contrário do que sustenta a Parte reclamada, a atividade de instalação e reparo de linhas e centrais telefônicas está ligada à sua atividadefim, sendo vedada a terceirização, sob pena de se permitir que empresa do ramo de telecomunicações funcione sem a presença de empregados, mas apenas prestadores de serviços. Estar-se-ia promovendo a precarização dos direitos dos trabalhadores, em confronto com os princípios constitucionais da dignidade da pessoa humana e da busca do pleno emprego, previstos nos arts. $1^{\circ}$, III e 170, VIII, da Carta Magna, respectivamente, e com o objetivo fundamental da República Federativa do Brasil de erradicar a pobreza e a marginalização e redução das desigualdades sociais e regionais, insculpido no item III do art. $3^{\circ}$ da Constituição Federal.

Por fim, ressalto que o conceito de subordinação deve ser examinado à luz da inserção do trabalhador na dinâmica do tomador de serviços, configurando a denominada subordinação estrutural, teoria que se adianta como proposta para solucionar os casos em que o conceito clássico de subordinação apresenta-se inócuo.

Nesse sentir, peço vênia para lançar as observações do eminente 
Ministro Maurício Godinho:

"Como se sabe, o conceito de subordinação hoje dominante é o que a compreende como a situação jurídica, derivada do contrato de emprego, em decorrência da qual o trabalhador acata a direção laborativa proveniente do empregador. É uma situação jurídica que se expressa por meio de certa intensidade de ordens oriundas do poder diretivo empresarial, dirigidas ao empregado.

(...)

A readequação conceitual da subordinação - sem perda de consistência das noções já sedimentadas, é claro -, de modo a melhor adaptar este tipo jurídico às características contemporâneas do mercado de trabalho, atenua o enfoque sobre o comando empresarial direto, acentuando, como ponto de destaque, a inserção estrutural do obreiro na dinâmica do tomador de serviços.

Estrutural é, pois, a subordinação que se manifesta pela inserção do trabalhador na dinâmica do tomador de seus serviços, independentemente de receber (ou não) suas ordens diretas, mas acolhendo, estruturalmente, sua dinâmica da organização e funcionamento.

A idéia de subordinação estrutural supera as dificuldades de enquadramento de situações fáticas que o conceito clássico de subordinação tem demonstrado, dificuldades que exacerbam em face, especialmente, do fenômeno contemporâneo da terceirização trabalhista. Nesta medida ela viabiliza não apenas alargar o campo de incidência do Direito do Trabalho, como também conferir resposta normativa eficaz a alguns de seus mais recentes instrumentos desestabilizadores - em especial, a terceirização." (DELGADO, Maurício Godinho. Direitos Fundamentais na Relação de Trabalho. Revista LTr, Ano 70, $\mathrm{n}^{\circ}$ 6, junho/2006, pág. 667).

Assim, considerando o quadro fático delineado pela Corte de origem, segundo o qual fora comprovada a terceirização de atividade-fim, entendo 
contrariada a Súmula 331, I, do TST.

Conheço, portanto, do recurso de revista.

\section{2 - MÉRITO.}

Conhecido o recurso por contrariedade à Súmula 331, I, do TST, no mérito, dou-lhe provimento, para declarar a nulidade da contratação por empresa interposta, reconhecendo o vínculo de emprego diretamente com a primeira Reclamada, Brasil Telecom S.A., e determinar o retorno dos autos à Vara de origem, para que julgue os demais pedidos à luz da premissa aqui estabelecida. Prejudicado o exame dos demais tópicos do recurso.

\section{$\underline{\text { ISTO POSTO }}$}

ACORDAM os Ministros da Terceira Turma do Tribunal Superior do Trabalho, por unanimidade, conhecer do recurso de revista por contrariedade à Súmula 331, I, desta Corte e, no mérito, dar-lhe provimento, para declarar a nulidade da contratação por empresa interposta, reconhecendo o vínculo de emprego diretamente com a primeira Reclamada, Brasil Telecom S.A., e determinar o retorno dos autos à Vara de origem, para que julgue os demais pedidos à luz da premissa aqui estabelecida. Prejudicado o exame dos demais tópicos do recurso.

Brasília, 22 de junho de 2011.

\section{ALBERTO LUIZ BRESCIANI DE FONTAN PEREIRA Ministro Relator}


NUMERO ÚNICO: 00910-2008-002-16-00-3-RO

DES (A). RELATOR (A): LUIZ COSMO DA SILVA JÚNIOR

DES (A). REVISOR (A): AMÉRICO BEDÊ FREIRE

DES (A). PROLATOR (A) DO ACÓRDÃO: LUIZ COSMO DA SILVA JÚNIOR

DATA DE JULGAMENTO: 27/08/2009 - DATA DE PUBLICAÇAO: 12/11/2009

\begin{abstract}
E M E N T A “TERCEIRIZAÇÃO - SUBORDINAÇÃO ESTRUTURAL - NOVA TENDÊNCIA - A subordinação, como requisito substancial, longe da visão clássica em que foi instituída a relação de emprego, quando o trabalhador estava submetido a uma disciplina rígida e direta do próprio empregador, tem, hoje, outros contornos diante das mutações das relações laborais, que ganham novo enfoque para se adequarem às exigências do mercado globalizado, sem afetar a principiologia protecionista que funda o Direito do Trabalho. Trata-se de interpretação ampliativa desse elemento, cujo escopo é atingir trabalhadores que não se inserem no conceito clássico de subordinação, mas estão afetos ao comando do empreendimento empresarial, em razão da prestação laboral. A festejada subordinação estrutural "se manifesta pela inserção do trabalhador na dinâmica do tomador de seus serviços, independentemente de receber (ou não) suas ordens diretas, mas acolhendo, estruturalmente, sua dinâmica de organização e funcionamento". Recurso conhecido e não provido
\end{abstract}

\title{
R E L A T Ó R I O
}

Trata-se de Recurso Ordinário interposto por Unibanco União de Bancos Brasileiros S.A. em face da sentença proferida pela $2^{\mathrm{a}}$ Vara do Trabalho de São Luís/MA, nos autos da reclamação trabalhista em que contende com Raimunda Aguiar Coqueiro.

Às fls. 176/183, o juízo a quo, após regular instrução do feito, rejeitou a preliminar de carência de ação; declarou a prescrição total do direito, ressalvando os pleitos declaratórios e de anotações em CTPS, em razão do que julgou procedente em parte o pedido, de modo a declarar nulo o contrato de trabalho firmado com a Prorevenda e reconhecer o vínculo de emprego diretamente com o Unibanco, condenando este último na obrigação de fazer consistente em retificar a CTPS da autora, no prazo de 48 horas, a partir 
da intimação da juntada do documento aos autos, sob pena de multa diária no valor de $\mathrm{R} \$ 500,00$, até o limite de $\mathrm{R} \$ 15.000,00$. Custas na forma da lei.

Às fls. 185/194, o banco reclamado pleiteia a reforma do julgado, sob a alegação de não ser o real empregador da reclamante, sendo certo que a contratante teria sido a Prorevenda, com quem mantinha um contrato de terceirização. Alega, ainda, não se verificaram presentes os requisitos do vínculo de emprego, quais sejam, não-eventualidade, onerosidade, pessoalidade e subordinação. Afirma, também, que os serviços prestados pela demandante se davam de forma predominantemente externa, $o$ que, de pronto, afastaria seu enquadramento como bancária e, se porventura houvesse que se dirigir ao Banco, seria apenas para enviar as proposta de concessão de financiamentos de automóveis dos consumidores captados junto às concessionárias de veículos, sendo essa a atividade exercida pela Prorevenda, que, através de seus empregados, fazia a análise da possibilidade ou não da concessão de crédito. Aduz que sua atividade está afeta a financiamento bancário, sendo que a outra demandada não atua nessa área, tendo como objetivo serviços diversos deste, tidos como de mero apoio, não compondo o núcleo de suas atividades-fins. Por fim, alega que, na hipótese de existir responsabilidade por mais de uma empresa, apenas se admita a subsidiária, já que a solidária deve decorrer da lei ou do contrato, o que não seria o caso em análise. Quer que o vínculo de emprego seja mantido com a Prorevenda.

Não houve contrarrazões, embora a reclamante tenha sido devidamente intimada às fls. 199.

É o relatório.

V O T O

\section{ADMISSIBILIDADE}

Recurso interposto no tempo e modo. Pelo conhecimento.

MÉRITO.

Da terceirização

A decisão a quo limitou-se a julgar o pedido pertinente ao vínculo de emprego, declarando nulo o firmado com a Prorevenda e determinando sua formação diretamente com o Unibanco. Quanto às parcelas pecuniárias, foram fulminadas pela prescrição.

O banco recorrente pauta sua tese na terceirização, que, no seu ver, ocorreu de forma regular, sendo certo que o legitimado para funcionar como empregador da reclamante seria a Prorevenda.

No atual contexto sócio-econômico, a terceirização é fenômeno que não pode mais ser evitado, haja vista que se tornou uma exigência do mercado para 
desenvolvimento da economia mundial, diante da expansão do capital, que ultrapassa as fronteiras dos Estados. Entretanto devemos entender que esse fato não deve trazer prejuízos aos direitos dos trabalhadores, precarizando ou excluindo o patamar mínimo conquistado ao longo dos anos. De fato, temos que aceitá-lo, porque é uma realidade que não retroage mais, porém devemos usá-lo em prol do trabalhador, buscando, nessa forma trilateral de relação laboral, maiores garantias aos direitos trabalhistas.

Isso porque o artigo $7^{\circ}$ da Magna Carta estabelece que devem ser assegurados aos trabalhadores, além dos direitos ali previstos, outros que visem à melhoria de sua condição social. Em outras palavras, os direitos constantes no referido dispositivo é, como diz Maurício Godinho Delgado, o patamar civilizatório mínimo. Aquilo que serve para garantir o mínimo existencial, logo o uso de qualquer instituto jurídico que venha de encontro a essa norma não é aceitável.

Sobre a terceirização não há, no Direito pátrio, uma legislação delimitando seu alcance, o que não significa possa ser usada contra os interesses do trabalhador, sob pena de se permitir um retrocesso social, o que é vedado pela força normativa dos princípios constitucionais.

No caso em tela, a recorrente quer seja tida como lícita a terceirização perpetrada, através do contrato de fls. 119/127, com a empresa Prorevenda Promotora de Vendas e Prestações de Serviços Ltda., contratada para prestar-lhe serviços de recepção e encaminhamento de pedidos de empréstimos e de financiamentos na qualidade de correspondente bancário dos contratantes, ou, ainda, o encaminhamento de propostas de arrendamento mercantil, também denominada como leasing, dentre outros serviços definidos nos itens c e $\mathrm{d}$ do contrato. Diz que a reclamante era vinculada a esta última e pretende, com isso, se ver livre da responsabilidade pelo pagamento dos direitos trabalhistas, o que não deve ser acolhido.

Ora, além do contrato citado não traduzir qualquer repercussão para os direitos da reclamante, observa-se que, na verdade, há um pacto de intermediação de mão-de-obra, o que é bem pior do que a terceirização. Esta se caracteriza por ser o processo de descentralização das atividades do tomador de serviços, que delega a terceiros parte de suas tarefas, mas que, segundo o constante na Súmula 331, II do c. TST, somente pode ocorrer em serviços especializados ligados à atividade-meio do empreendimento.

No caso, vê-se que a prestação de serviços da obreira estava vinculada a atividade-fim do recorrente, já que laborava na área de operações financeiras nas dependências do próprio Unibanco, segundo afirma em seu depoimento, às fls. $\underline{52 / 53}$. Sobre tal aspecto, diz o preposto do banco reclamado, à fl. 53, que hoje a Prorevenda pertence $100 \%$ ao Unibanco, mas, na época em que a reclamante trabalhava, esse 
percentual era de $49 \%$.

Diante de tais fatos, podemos concluir que a Prorevenda funcionava como uma simples intermediadora dentro do próprio Unibanco, prestando serviços insertos nos fins propostos pelo último, funcionando apenas como uma descentralizadora das operações típicas da empresa, mas não como mera colaboradora, como quer fazer crer o recorrente. Isso tanto é verdade que, atualmente, foi totalmente encampada pelo segundo demandado.

Essa circunstância apenas reforça a tese da ilicitude da suposta terceirização, aliada ao fato de que os elementos consubstanciadores do vínculo laboral com a recorrente restaram caracterizados, sendo a prestação de serviço pessoal, onerosa e não-eventual.

Quanto à subordinação, como requisito substancial, longe da visão clássica em que foi instituída a relação de emprego, quando o trabalhador estava submetido a uma disciplina rígida e direta do próprio empregador, tem, hoje, outros contornos, diante das mutações das relações laborais, que ganham novo enfoque para se adequarem às exigências do mercado globalizado, sem afetar a principiologia protecionista que funda o Direito do Trabalho.

Fale-se em subordinação objetiva, que, no dizer de Lorena Vasconcelos Porto, em artigo publicado na Revista LTr de julho/2008, intitulado "Relação de emprego e a subordinação - A matriz clássica e as tendências expansionistas", pág. 7207/824, "se revela na integração da atividade do trabalhador na atividade da empresa. Ela se faz presente quando o objeto do contrato de trabalho, isto é, a função a ser exercida pelo empregado, as tarefas que ele deve executar, se integram e se incorporam na atividade empresarial, compondo a dinâmica geral da empresa, em seu processo produtivo ou de fornecimento de bens e serviços. Assim, a atividade obreira é crucial para a consecução dos objetivos da empresa, sejam eles econômicos, técnicos, operacionais ou administrativos.".

Essa nova tendência ampliativa tem como escopo atingir trabalhadores que não se inserem no conceito clássico de subordinação, mas estão afetos ao comando do empreendimento empresarial, em razão da prestação laboral. Escreve a autora retrocitada: "De acordo com Fayol, a direção empresária é articulada em ações complexas, classificadas em: previsão; organização; comando; coordenação e controle. Assim, o exercício do poder diretivo não se limita somente ao comando e ao controle (no qual o autor inclui o poder disciplinar), mas se revela também na coordenação e na organização. Se há a prestação de uma atividade pessoal para a empresa, com a qual o empregador conta, em sua normal previsão, há o exercício de poder diretivo sobre esse trabalhador, 
pois a sua prestação integra, necessária e continuamente na atividade geral da empresa. Com efeito, o empregador conta com a sua continuidade e regularidade para a consecução dos fins empresariais." .

Mauricio Godinho Delgado, nas palavras de Francisco C. Lima Filho, em artigo publicado no site www.trt24.jus.br, "defende a ampliação do conceito de subordinação propondo que seu ponto de identificação seja a inserção estrutural do obreiro na dinâmica do tomador de serviço" .

Em seguida, afirma o citado autor: "Estrutural é, pois, a subordinação que se manifesta pela inserção do trabalhador na dinâmica do tomador de seus serviços, independentemente de receber (ou não) suas ordens diretas, mas acolhendo, estruturalmente, sua dinâmica de organização e funcionamento" .

Ainda citando Francisco C. Lima Filho, esse posicionamento foi acolhido pela $1^{\text {a }}$ Turma do Tribunal Regional do Trabalho da $3^{\text {a }}$ Região, no julgamento do RO 00059-2007-011-03-00-0, cuja ementa encontra-se assim vazada: TERCEIRIZAÇÃO E SUBORDINAÇÃO ESTRUTURAL. No exercício da função de instalador/emendador de cabos telefônicos, o autor exercia função perfeita e essencialmente inserida nas atividades empresariais da companhia telefônica (TELEMAR). E uma vez inserido nesse contexto essencial da atividade produtiva da empresa pósindustrial e flexível, não há mais necessidade de ordem direta do empregador, que passa a ordenar apenas a produção. Nesse ambiente pós-grande indústria, cabe ao trabalhador ali inserido habitualmente apenas "colaborar". A nova organização do trabalho, pelo sistema da acumulação flexível, imprime uma espécie de cooperação competitiva entre os trabalhadores que prescinde do sistema de hierarquia clássica. Em certa medida, desloca-se a concorrência do campo do capital, para introjetá-la no seio da esfera do trabalho, pois a própria equipe de trabalhadores se encarrega de cobrar, uns dos outros, o aumento da produtividade do grupo; processa-se uma espécie de sub-rogação horizontal do comando empregatício. A subordinação jurídica tradicional foi desenhada para a realidade da produção fordista e taylorista, fortemente hierarquizada e segmentada. Nela prevalecia o binômio ordem-subordinação. Já no sistema ohnista, de gestão flexível, prevalece o binômio colaboração-dependência, mais compatível com uma concepção estruturalista da subordinação. Nessa ordem de idéias, é irrelevante a discussão acerca da ilicitude ou não da terceirização, como também a respeito do disposto no art. $\underline{94}$, II da Lei 9.472/97, pois no contexto fático em que se examina o presente caso, ressume da prova a subordinação do reclamante-trabalhador ao empreendimento de telecomunicação, empreendimento esse que tem como beneficiário final do excedente do trabalho humano a companhia telefônica. Vale lembrar que na feliz e contemporânea conceituação da $\underline{\text { CLT }}$ - artigo $\underline{2^{\circ}}$, caput - o 
empregador típico é a empresa e não um ente determinado dotado de personalidade jurídica. A relação de emprego exsurge da realidade econômica da empresa e do empreendimento, mas se aperfeiçoa em função da entidade final beneficiária das atividades empresariais.

Nessa esteira, como já dito acima, a obreira prestava serviços para o Unibanco e, embora constasse como sua empregadora a Prorevenda, a sua energia de trabalho era destinada àquele, em atividades insertas na dinâmica empresarial, ligados aos fins do empreendimento, sendo certo ser o Banco o verdadeiro empregador.

Tratando-se de subordinação vista sob o enfoque da estrutura empresarial, é irrelevante o fato de o trabalhador prestar serviços em atividades fins ou meios do tomador, já que o que caracteriza a relação jurídica de emprego e, por via de consequência, a incidência das normas protetivas laborais, é, segundo o autor retrocitado, o fato de não agir no seio de uma organização própria antes de se integrar numa organização de meios produtivos alheia, dirigida à obtenção de fins igualmente alheios, o que implica de sua parte, a submissão às regras que exprimem o poder de organização do empresário, à autoridade deste, em suma, derivada da sua posição nas relações de produção.

Para concluir, citamos, ainda, os ensinamentos do Magistrado do Mato Grosso do Sul, acima mencionada; "A nova organização do trabalho, pelo sistema da acumulação flexível, imprime uma espécie de cooperação competitiva entre os trabalhadores que prescinde do sistema de hierarquia clássica", pois "a subordinação jurídica tradicional foi pensada para a realidade da produção fordista e taylorista, fortemente hierarquizada e segmentada, ao passo que"no sistema ohnista, de gestão flexível, hoje prevalecente na grande maioria das empresas, prevalece o binômio colaboração-dependência, mais compatível com uma concepção estruturalista da subordinação"

Assim, voto pela manutenção da sentença.

A C Ó R D A O Por tais fundamentos, ACORDAM os Desembargadores do Tribunal Regional do Trabalho da $16^{\mathrm{a}}$ Região, por unanimidade, conhecer do recurso e, no mérito, negar-lhe provimento para manter a decisão de $1^{\circ}$ grau. 


\section{A C Ó R D Ã O}

\section{$2^{\mathrm{a}}$ TURMA}

Relator : Des. FRANCISCO DAS C. LIMA FILHO

Revisor : Des. JOÃO DE DEUS GOMES DE SOUZA

Origem : $1^{\text {a }}$ Vara do Trabalho de Campo Grande - MS

1. RELAÇÃO DE EMPREGO. MONTADOR DE MÓVEIS . SUBORDINAÇÃO ESTRUTURAL - Incontroverso o trabalho, firma-se em favor do trabalhador montador de móveis de empresa que tem na comercialização de móveis montados sua atividade-fim, a presunção de que o labor foi realizado de forma subordinada com a inserção do obreiro na estrutura da empresa que se apropriava da sua força de trabalho. A mera exibição de recibo de pagamento por -prestação de serviço autônomo- não serve para infirmar a presunção de subordinação estrutural do obreiro à empresa, não tendo tal documento o condão de, por si só, demonstrar a autonomia da prestação laboral. 2. REDUÇÃO SALARIAL. VIOLAÇÃO À GARANTIA CONSTANTE DO ART. 468 DA CLT 2. REDUÇÃO SALARIAL. VIOLAÇÃO À GARANTIA CONSTANTE DO ART. 468 DA CLT - Comprovada a redução das comissões pelos serviços prestados, em agressão à garantia constante do art. 468 daCLT, correta a sentença que, além de reconhecer o vínculo de emprego com determinação de anotações do contrato na CTPS, condena a empregadora na diferença salarial postulada. Recurso improvido neste particular.

\section{R E L A T Ó R I O}

Vistos, relatados e discutidos estes autos (PROCESSO No 0854/2008-001-24-00-7-RO.1), em que são partes as acima indicadas.

Com o objetivo de reformar a r. sentença de f. 194/208, proferida pelo Exm. ${ }^{\circ}$ Juiz Rodnei Doreto Rodrigues, que acolheu em parte os pedidos constantes da exordial, recorre a reclamada às f. 210/223. 


Em suma, quer se livrar da $\begin{array}{r}\text { condenação. } \\ \text { Não houve resposta ao recurso }\end{array}$
Depósito recursal e custas às f. $221 / 222$.

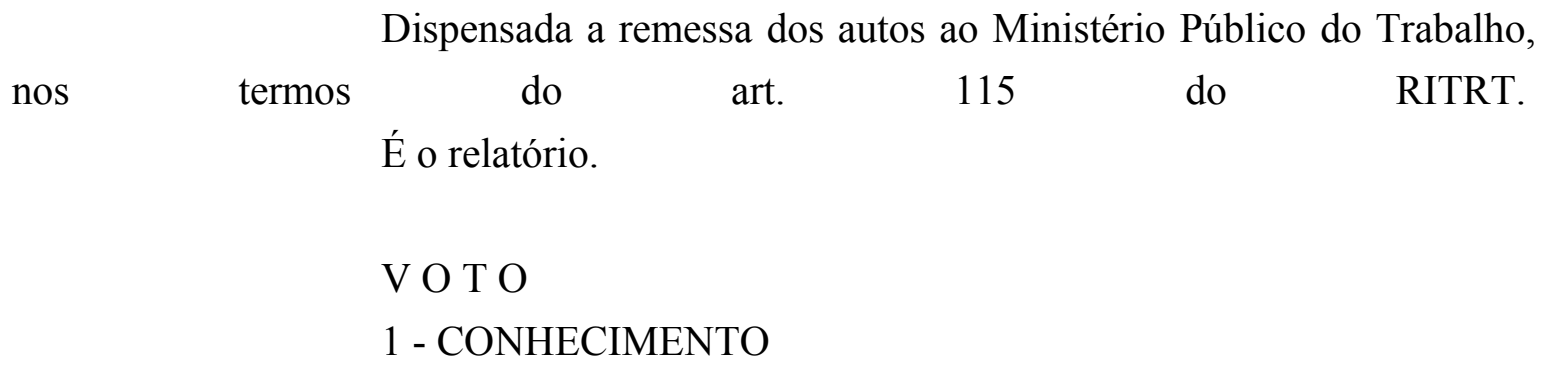

O recurso foi interposto via fac-símile às f. 210/223 e os originais foram exibidos oportunamente às f. 225/238.

Presentes os pressupostos de cabimento e admissibilidade, conheço do recurso.

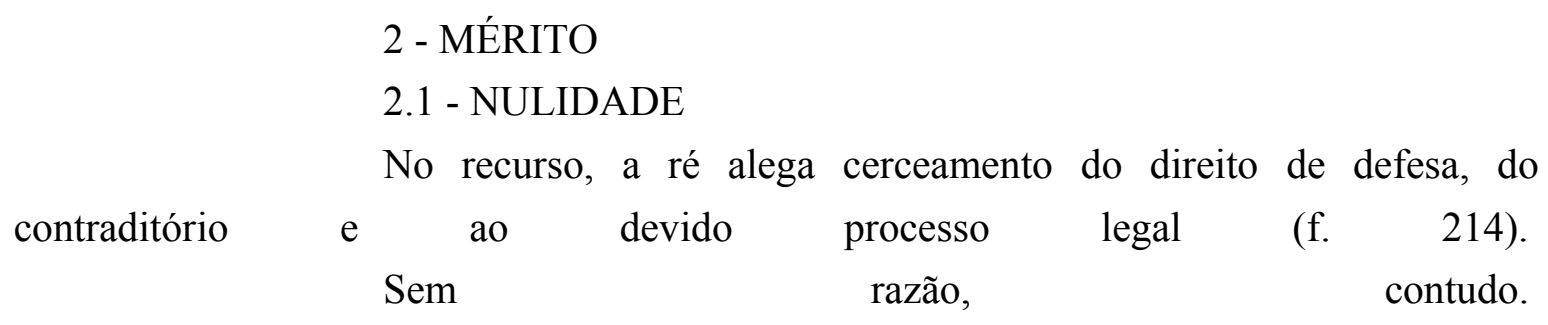

Não há notícia nos termos de f. 39 e 183 da prova requerida pela recorrente que não tenha sido colhida. Tampouco há registro de que lhe tenha sido negada oportunidade para manifestação, de sorte que essa pode reagir ao postulado na forma da lei. Ademais, sobreleva notar que a instrução findou sem qualquer protesto, o que implica afirmar que toda e qualquer discussão a respeito da prova restou preclusa. Diante disso, não há se cogitar em violação à ampla defesa, contexto em que se insere o contraditório, dimensões da garantia ao devido processo. Note-se que eventual insucesso no plano meritório por deficiência probatória, não resulta em violações às mencionadas garantias, máxime quando a instrução foi encerrada sem qualquer manifestação ou protesto da recorrente. Nega-se provimento.

\section{$2.2 \quad-\quad$ DIFERENÇAS DE COMISSÕES}

Trata-se de recurso da empresa no qual, essencialmente, busca eximir-se da condenação ao pagamento de diferenças de comissões e reflexos. 
Vejamos, pois, uma síntese do processado.

Na peça de ingresso o demandante disse que começou a trabalhar em 12.11.2004, embora tenha tido o contrato formalizado em 18.8.2005, na condição de montador de móveis e com percepção de comissões pela montagem de móveis. Informa que a partir do registro do pacto na sua CTPS, a tabela relativa às comissões, por montagem, foi reduzida, ou seja, - a reclamada alterou a tabela de preços, passando as montagens de móveis com valor inferior a tabela anterior relativo ao período sem registro -.

Nesse passo, entende ilícita a redução salarial para pedir que - seja aplicado sobre as comissões recebidas a contar de setembro/2005 até a data da demissão, o percentual de 49,255\% - (f. 6), bem assim os respectivos reflexos. Na defesa, a demanda sustentou que - enquanto autônomo, não havia salário fixo, mas sim, comissões variáveis, uma vez que a contraprestação dos serviços realizados pelo reclamante era à base de comissão por móvel montado. E a partir 18.08.2005, quando o reclamante foi contratado como empregado da reclamada, sua remuneração também for estipulada por tarefa - (f. 42), pugnando, a final pela a improcedência do pleito.

A sentença, a par de ordenar a empresa na retificação das anotações na CTPS do trabalhador (f. 199), deferiu as diferenças postuladas (f. 200/203), com o que não se conforma a demandada.

No recurso, a reclamada aduz que o autor, na condição e enquanto autônomo, teve salário diferenciado porque - todas as despesas corriam a seu cargo, principalmente a contratação de ajudante de montagem, o que era remunerado pelo próprio obreiro - (f. 214) e, - ao ser registrado, a responsabilidade do pagamento do ajudante de montagem passou a ser exclusivamente da recorrente, sendo certo que a partir de então, o recorrido não mais teve que despender qualquer valor a este mister - (f. 214). Contudo, razão não lhe assiste.

De início, pondere-se que não passa despercebido que a demandada noticia aspectos fáticos em sede recursal pela primeira vez. Ora, na defesa constante de f. 42/48 não há qualquer alegação de que a melhor remuneração inicial era em razão de o autor ter, à época, de pagar ajudante.

A rigor, seria o caso de não se conhecer dessa tese, mas não há prejuízo irreparável em seguir no julgamento da questão, tal como formulada. Superado esse aspecto e malgrado inexistir pedido recursal certo a respeito da retificação das anotações da CTPS, ordenada pela sentença, convém pontuar que o reclamante foi empregado desde o início, conforme acertadamente sentenciado. 
Com efeito, é de sabença geral até mesmo em razão das propagandas na mídia, especialmente a televisiva, que a recorrente ré comercializa móveis montados, motivo pela qual a montagem está inserida na sua atividade-fim sendo assim indispensável aos seus objetivos, o tipo de labor prestado pelo recorrido.

Nesse sentido, conforme decidido em caso análogo por esta Turma Regional, no processo de n. ${ }^{\circ}$ 0705/2007-007-24-00-5-RO.1, relatado pelo Exm. ${ }^{\circ}$ Juiz João Marcelo Balsanelli, -em se tratando de móveis, o costume não é comprar para montar, pois a expectativa do consumidor é receber o móvel em condições de uso. Logo, insere-se na atividade-fim da ré a montagem dos móveis que vende -.

De todo modo, por ser incontroverso o trabalho, firmou-se a presunção de que a atividade do reclamante, onerosa e não-eventual, foi realizada com subordinação até mesmo pela inserção do obreiro na estrutura da empresa que se apropriava da sua força de trabalho, fato este que a demandada não logrou infirmar.

Parece óbvio que mera exibição de recibo de pagamento a autônomo não serve para infirmar a presunção de subordinação estrutural do autor à empresa, não parece óbvio que mera exibição de recibo de pagamento a autônomo não serve para infirmar a presunção de subordinação estrutural do autor à empresa, não tendo tal documento o condão de, por si só, demonstrar a autonomia da prestação laboral.

Não bastasse isso, o exame da prova oral confirma que o trabalho dos montadores de móveis da recorrente sempre foi o mesmo, conforme se vê, por exemplo, à f. 186. Aliás, em juízo (f. 188), o preposto esclareceu que o pagamento feito anteriormente ao registro, visou remunerar apenas a montagem de móveis.

Prevalece a conclusão de que o vínculo jurídico tem natureza empregatícia desde o seu início, até mesmo porque não houve qualquer modificação das atribuições do obreiro posteriormente à formalização do contrato. Injustificável, portanto, à luz do disposto no art. 468 da CLT, a indiscutível redução salarial perpetrada pela reclamada pelo que, correta a condenação imposta origem.

Nessa perspectiva, sobreleva anotar que a defesa se firmou em fato modificativo. Vale dizer, a ré reconheceu a existência de redução remuneratória, embora negue o percentual alegado pelo autor. Cabia-lhe, pois, comprovar a procedência, dada afirmação de que - todos os documentos acostados na inicial, em especial, a suposta tabela de preços, uma vez que nada comprova, tratando-se de documentos unilaterais e que poderiam ser confeccionados por qualquer pessoa- (f. 48). Porém, não há nos autos qualquer resquício de prova nesse sentido. Frise-se, ainda, por importante, que a forma de pagamento salarial exige demonstração da 
produção atingida. A despeito do que dispõe o art. 464 da CLT, a demandada, injustificadamente, não exibiu prova sobre o aspecto quantitativo do trabalho do demandante.

Cabia, insista-se, à reclamada comprovar a incorreção dos valores articulados na exordial, porque ao admitir na defesa a redução salarial, não afirmou os percentuais que utilizava para o pagamento, tampouco evidenciou o aspecto quantitativo do trabalho do recorrido.

Nesse contexto, prevalecem os valores articulados na peça de ingresso. No mais, nem mesmo em sede recursal a ré logrou infirmar a constatação pela sentença quanto à existência da indigitada redução salarial (f. 201/202).

Por fim, constata-se que a sentença deferiu - diferenças mensais de comissões correspondentes a 49,25\% dos valores lançados nos recibos de pagamento relativos ao período iniciado em 18/11/05 até 27/11/07, quando foi dispensado imotivadamente- (f. 202), o que não merece retoque. Impõe-se, assim, o desprovimento ao recurso empresarial nesta parte.

\section{$2.3 \quad-\quad$ LITIGÂNCIA DE MÁ-FÉ}

A sentença condenou a reclamada por litigância de má-fé, por entender que é insustentável a defesa no sentido de que são unilaterais as tabelas indicadas pelo autor, o que não foi contestado em outro processo que tramitou perante a origem. Nessa direção, concluiu que (f. 201):

- Na verdade, essa negativa é de manifesta má-fé , posto que, em cópia de ata juntada aos autos pelo autor, a testemunha da própria acionada, naqueles autos, admitiu que houve redução dos valores tabelados para as montagens (item 3, fl. 20).

Mais que isso, no próprio Acórdão que lhe foi favorável, transcrito pela demandada em sua defesa, há expressa referência ao desmembramento do valor das comissões que eram pagas ao montador, em valores a serem pagos a ele e a eventual ajudante (fl. 44).

Tenho, portanto, como caracterizada a litigância de má-fé, por alteração da verdade dos fatos, razão pela qual condeno a acionada a indenizar ao autor a importância de $\mathrm{R} \$$, atualizável a contar da data da ciência desta decisão, com espeque no art. 17 , II, e art. $18, \S 2^{\circ}$, do CPC. -

Insurge-se a reclamada contra a condenação ao argumento de que apenas exercitou seu direito de ação (f. 212/213). Acrescenta que expôs os fatos sem alteração da verdade para pedir a improcedência do pedido. Com razão, data venia do que entendido na origem. 
$\mathrm{O}$ exame minucioso das manifestações da recorrente não revela qualquer incoerência. $\mathrm{O}$ fato de não repetir a mesma defesa formulada em outro processo, não significa, por si só, deslealdade.

Demais disso, destaca-se que a divergência diz respeito a fatos controvertidos, que nem sempre são idênticos, mesmo em se tratando de empregados na mesma atividade. Não vislumbro, pois, prova de alteração da verdade.

Em razão disso, dou provimento ao recurso, nesta parte, para absolver a recorrente da condenação por litigância de má-fé.

\section{POSTO ISSO}

ACORDAM os Desembargadores da Egrégia Segunda Turma do Tribunal Regional do Trabalho da Vigésima Quarta Região, por unanimidade, em aprovar o relatório, conhecer do recurso e, no mérito, dar-lhe provimento parcial apenas para absolver a reclamada da condenação por litigância de má-fé, nos termos do voto do Desembargador Francisco das C. Lima Filho (relator). Mantém-se o valor arbitrado à condenação.

Campo Grande, 25 de março de 2009.

FRANCISCO DAS C. LIMA FILHO

\section{Desembargador Federal do Trabalho}

Relator 
NUMERO ÚNICO: 01662-2008-015-16-00-4-RO

DES (A). RELATOR (A): AMÉRICO BEDÊ FREIRE

DES (A). PROLATOR (A) DO ACÓRDÃO: AMÉRICO BEDÊ FREIRE

DATA DE JULGAMENTO: 18/01/2011 - DATA DE PUBLICAÇAO: 24/01/2011

\section{E M E NT A}

RELAÇÃO DE EMPREGO. NÃO CONFIGURAÇÃO. VERBAS TRABALHISTAS INDEVIDAS. Considerando que, do conjunto probatório, não se extrai a presença dos elementos fático-jurídicos configuradores da relação de emprego entre reclamante e reclamadas, de forma que o autor prestou serviços de escolta de mercadorias de forma autônoma, sem qualquer subordinação, tem-se por correta a sentença de base que afastou o alegado vínculo empregatício e indeferiu o pagamento das parcelas trabalhistas ao obreiro.Recurso ordinário conhecido e não provido.

\section{R E L A T Ó R I O}

Vistos, relatados e discutidos os presentes autos de Recurso Ordinário oriundos da $5^{\text {a }}$ Vara do Trabalho de São Luís/MA, em que são partes MANOEL MESSIAS LIMA (recorrente), AMBEV - COMPANHIA DE BEBIDAS DAS AMÉRICAS e EMPRESA DE ÔNIBUS NOSSA SENHORA DA PENHA S.A. (recorridos). Após a instrução do feito, a magistrada a quo, às fls. 416/422, declarou a inexistência de vínculo empregatício entre as partes e julgou improcedentes os pedidos formulados na inicial. O Sr. Manoel Messias, inconformado com a decisão, interpôs Recurso Ordinário às fls. 425/437, sustentando, em resumo, que estariam presentes, no caso, todos os requisitos necessários para a caracterização da relação de emprego entre recorrente e recorridas, de forma que estas deveriam ser condenadas no pagamento de todas as verbas trabalhistas decorrentes do pacto.

Contra-razões da "AMBEV" e da "EMPRESA DE ÔNIBUS NOSSA SENHORA DA PENHA", respectivamente, às fls. 443/456 e 457/466. Defendem as empresas, preliminarmente, a deserção do recurso do autor, por falta de preparo, e, no mérito, a improcedência dos pleitos formulados na reclamação. É o relatório.

V O T O

Admissibilidade - da preliminar de deserção do recurso ordinário suscitada pelas reclamadas As reclamadas sustentam, em contra-razões, que o apelo do autor seria deserto, pois o mesmo, não sendo beneficiário da justiça gratuita, não procedeu ao pagamento das custas recursais, nos termos do art. $\underline{89}$ da $\underline{\text { CLT. Aponta a }}$ 
"EMPRESA DE ÔNIBUS NOSSA SENHORA DA PENHA", ainda, como empecilhos ao recebimento do recurso, o fato de o reclamante não ter requerido o benefício quando da petição inicial, de a gratuidade da justiça não ter sido pedida ao juízo de base, mas ao Egrégio TRT (já que o pleito nesse sentido encontra-se em razões recursais), e de o recorrente não se tratar de pessoa hipossuficiente (pois ganharia de $\mathrm{R} \$ \mathrm{a} 2.100,00$, contaria com advogado particular, seria solteiro e moraria em bairro de classe média). Tais argumentos não merecem amparo. Primeiramente porque o benefício de isenção de custas pode ser formulado em qualquer tempo ou grau de jurisdição, não havendo empecilhos quanto à sua concessão em sede recursal. Nesse sentido é a redação da OJ n ${ }^{\circ} 269$, da SDI1, do c. TST:JUSTIÇA GRATUITA. REQUERIMENTO DE ISENÇÃO DE DESPESAS PROCESSUAIS. MOMENTO OPORTUNO. Inserida em 27.09.02 - O benefício da justiça gratuita pode ser requerido em qualquer tempo ou grau de jurisdição, desde que, na fase recursal, seja o requerimento formulado no prazo alusivo ao recurso. Incabíveis, pois, as alegações da "EMPRESA DE ÔNIBUS NOSSA SENHORA DA PENHA" quanto ao momento do pedido de isenção e à impossibilidade da sua apreciação pelo juízo de base. Afinal, o verbete é claro ao permitir o requerimento em fase recursal, dentro do prazo alusivo ao apelo, e não faz qualquer exigência quanto à sua formulação na peça de interposição ou nas razões recursais. E nem poderia ser diferente, diante do princípio da simplicidade que reina no processo do trabalho e impede a exigência de formalidades que somente dificultam o acesso à Justiça. Dessarte, não vejo problemas no fato de o juízo de base apreciar pedido nesse sentido, seja em que ponto da peça recursal ele esteja, razão pela qual restam infundadas as alegações da recorrida de que, formulado em razões recursais, o pleito de justiça gratuita só poderia ser analisado pelo TRT .

De qualquer forma, entendo que o benefício da justiça gratuita, no caso, foi corretamente concedido, vez que, para a caracterização da hipossuficiência, não importa que autor ganhe de $\mathrm{R} \$ 1.500,00$ a $\mathrm{R} \$ 2.500,00$, seja solteiro, tenha advogado particular ou não resida no subúrbio da cidade. Isso porque, para tanto, basta a simples afirmação da parte de que não está em condições de pagar as custas do processo e os honorários de advogado sem prejuízo próprio ou de sua família (art. $\underline{4}^{\mathrm{o}}$ da Lei $\underline{1.060} / 50$, aplicável à situação por via análoga), requisito este observado, como se vê às fls. 428/429 dos autos. Rejeito, por essas razões, a preliminar de deserção aduzida pelas reclamadas.

De resto, preenchidos os requisitos genéricos de admissibilidade, conheço do recurso ordinário. Mérito Alega o reclamante que estariam presentes, no caso, todos os elementos necessários para a caracterização de vínculo empregatício entre ele e as recorridas, e que, por conta disso, faria jus ao pagamento das parcelas trabalhistas vindicadas na inicial. Sustenta que a bilateralidade, apontada pelo 
juízo a quo como requisito da relação de emprego, na verdade, seria apenas uma característica do contrato de trabalho, por depender este da vontade de duas ou mais pessoas. Afirma que tal atributo não consta dentre os elementos caracterizadores do liame empregatício, nos termos do art. $\underline{3^{0}}$ da $\underline{\text { CLT }}$, mas que, de qualquer forma, a relação entre as partes era marcada pela bilateralidade, pois o obreiro cumpria com todos os seus deveres perante AMBEV. Ressalta que seu superior hierárquico era o Cabo Elias, também funcionário da $\mathrm{AMBEV}$, que exercia a função de gerente das atividades desempenhadas pelos seguranças e era responsável pela distribuição destes para efetuarem a proteção dos caminhões e produtos da primeira reclamada durante as entregas, pois tal providência era necessária, já que alguns seguranças são policiais militares e trabalham em regime de escala, de maneira que deveria haver um mínimo de organização para que o serviço de escolta fosse realizado de forma eficiente, sem que surgisse incompatibilidade de horários entre os dois ofícios.

No tocante à pessoalidade, registra que não seria afastada pelo fato de ter ele firmado em juízo que não manteve contato com a reclamada, mas apenas com o Cabo Elias, e que, estando impossibilitado de acompanhar a escolta, o Cabo Elias indicava outra pessoa da equipe para fazer o serviço (v. fls. 352 e 353). Isso porque, apesar dessas declarações, este nunca deixou de fazer as escoltas, não sendo necessária, pois, a sua substituição, de forma que sua resposta quanto a poder ser substituído se deu apenas por mera suposição e pelo fato de ser leigo, juridicamente falando. Destaca, também, que, por mais que tivesse sido substituído em serviço, tal substituição se daria tão somente de maneira esporádica, e que, devido à especificidade da relação (mantida com Policial Militar), a pessoalidade deveria ser mitigada, não podendo as recorridas alegarem a substituição eventual como fato impeditivo do vínculo de emprego. Em relação à subordinação, observa que não tinha autonomia na execução do seu ofício e era obrigado a cumprir ordens, exercendo sua atividade sob dependência do empregador. Ressalta que a subordinação, in casu, decorreria da própria habiltualidade, esta já reconhecida pelo juízo de base, que não poderia deixar o serviço a qualquer hora ou deixar de trabalhar quando quisesse e que deveria observar os comandos que lhe eram passados com o fito de assegurar as entregas de mercadorias. Ademais, tendo em vista o princípio da eventualidade, assevera que, havendo o entendimento de que o Cabo Elias era um terceiro na relação de trabalho, o vínculo empregatício deveria ser formado entre recorrente e recorridas, pois o Cabo Elias, não sendo pessoa jurídica, não teria condições de arcar com as verbas trabalhistas decorrentes do contrato. Invoca, para reforçar esse entendimento, a Súmula $\underline{331}$ do TST, incisos I e IV.

Razão não lhe assiste. Quanto à "EMPRESA DE ÔNIBUS 
NOSSA SENHORA DA PENHA" tenho que não há como imputar à mesma qualquer responsabilidade pelo alegado vínculo, vez que o reclamante deixou claro em audiência que nunca recebeu salário ou ordens de qualquer pessoa desta, e que sua relação era apenas com a reclamada AMBEV (v. fls. 353). Logo, assim como juízo a quo, não vejo outra decisão a ser tomada que não a improcedência de todos o pedidos formulados em face da segunda reclamada, com quem o reclamante firmou não ter nenhuma relação. $\mathrm{O}$ mesmo ocorre em relação à AMBEV. Compulsando os autos, observo que o reclamante juntou à inicial, para comprovar o alegado vínculo, somente uma nota fiscal emitida pela AMBEV, datada de 31 de julho de 2008, e algumas "requisições de escolta", referentes a 4 (quatro) dias dos meses de abril e maio de 2008 e a um dia do mês de junho do mesmo ano (v. fls. 10/13), onde se apôs, aleatoriamente, o nome do reclamante (veja-se que, na nota fiscal, o nome"Manoel Missias Lima"consta de espaço"Reservado ao Fisco"). Tais documentos, no nosso entender, não cumprem o seu desiderato (qual seja, a demonstração da relação de emprego entre as partes), já que, em momento algum, apontam o reclamante como empregado da AMBEV ou comprovam o trabalho não eventual deste em favor da empresa, e levam a crer, no máximo, que em alguns dias o obreiro realizou a escolta de veículos, ao que parece, pertencentes à "Penha Cargo", com quem o reclamante destacou que não mantinha qualquer relação, em companhia do Sr. "Elias Jr.", referido como "Segurança" nas "requisições de escolta" juntadas.

Nesse sentido, não socorre ao obreiro o argumento de que sua relação com a AMBEV era marcada pela bilateralidade. Afinal, tal característica somente se faria presente se as partes assumissem entre si obrigações recíprocas, passando elas, simultaneamente, a ser credoras e devedoras umas das outras, o que, no caso, ocorreria se a AMBEV, de fato, tivesse contratado os serviços do autor.

Acontece que, como visto acima, os documentos em questão não ligam o obreiro diretamente à AMBEV (pois não posso considerar como prova desse liame a simples aposição do nome do autor na nota fiscal de fls. 10 - em espaço indevido, diga-se de passagem), mas somente ao Sr. Elias (isto se considerarmos as requisições de escolta de fls. 11/13 juntamente com os depoimentos colhidos em juízo, como veremos à frente), que, segundo o autor, seria empregado da reclamada e chefe da equipe de segurança da qual o obreiro fazia parte. Vejamos o que dispôs o reclamante sobre essa relação (v. Fls. 352):

(...) que prestava serviços para a AMBEV nos bairros Liberdade, São Francisco e Anjo da Guarda; que foi chamado pelo Cabo Elias, para prestar serviços na AMBEV; que o cabo Elias foi o PM contratado pela AMBEV e o responsável por formar a equipe que prestaria serviços para a $\mathrm{AMBEV}$; que recebia o 
valor de sua remuneração das mãos do Cabo Elias, que por sua vez recebia da AMBEV; (...)

Desta feita, considerando que a alegada ligação entre o reclamante e a AMBEV se daria por meio do Sr. Elias, apontado como superior hierárquico do obreiro, tenho por fundamental, para considerar a existência de bilateralidade na relação AMBEV-autor, que o Sr. Elias fosse empregado da reclamada. Entretanto, na situação, o laborista não comprovou a existência de vínculo de emprego entre o Sr. Elias e a AMBEV, ônus que era seu, nos termos dos art. $\underline{818}$ da $\underline{\text { CLT e } \underline{33} 3}$, $\underline{\mathrm{I}}$, do $\underline{\mathrm{CPC}}$. Nesse sentido, a única testemunha indagada sobre o tema (policial que, inclusive, prestava serviços de escolta antes do recorrente), somente destacou (v. Fls. 355):

(...) que o senhor de nome Elias, que é membro do GTA e também bombeiro, foi a pessoa que chamou o depoente para prestar esse tipo de serviço; que o Sr. Elias era o representante da equipe que prestava esse serviço junto à $\mathrm{AMBEV}$; que não sabe dizer se o Sr. Elias era empregado da AMBEV (...) (Grifou-se)

Conclui-se, daí, apenas que o Sr. Elias convocava policiais para a realização de escoltas de mercadorias para a AMBEV, mas não que era, de fato, empregado desta. Para isso, far-se-ia necessário a efetiva demonstração da subordinação deste perante a empresa, o não se verificou na situação, vez que a única testemunha que tratou do vínculo registrou não saber se o Cabo da PM era empregado da AMBEV. Observe-se, ainda, o que dispôs a mesma pessoa (no caso, o Sr. Luís Henrique Silva, também policial militar) sobre a sistemática do serviço de escolta (v. Fls. 355):

(...) que o salário pago para o depoente era feito pelo Sr. Elias, que recebia de um empregado da AMBEV chamado Paulo; que o depoente deixou de prestar esse serviço no começo de 2004 e o reclamante ficou em seu lugar (...) que o Sr. Paulo, empregado da AMBEV, entrava em contato com o Sr. Elias, que por sua vez ligava para o depoente para que fosse acompanhar a rota; que o serviço de escolta dependia da folga de cada um da equipe; que em média trabalhava três vezes por semana; que o pagamento era quinzenal (...) que não sabe dizer se o Sr. Paulo acima mencionado era empregado da AMBEV ou de outra empresa que funcionava naquele local, a única coisa que sabe é que hoje funciona a empresa AMBEV no mesmo local onde prestou serviços no passado (...) 
Desse depoimento se extrai que a escolta era realizada com certa frequência e "chefiada" pelo Sr. Elias, sempre que solicitada por um homem chamado "Paulo", o qual, como visto, também não se pode afirmar que era funcionário da AMBEV, diante da dúvida da testemunha quanto a esse fato. Logo, mais uma vez se afasta o controle da reclamada sobre o serviço de escolta (e, por consequência, a bilateralidade e a subordinação da relação), já que nem o Sr. Elias, apontado como superior hierárquico do autor, nem o Sr. Paulo, que seria, em tese, o solicitante do trabalho dos seguranças, têm ligação comprovada com a AMBEV. De todo modo, mesmo em se admitindo que os serviços de segurança eram requisitados pela reclamada ao Sr. Elias, não vejo, no caso, traços de vínculo de emprego da AMBEV, seja com o "coordenador" da escolta (Cabo Elias), seja com o reclamante, já que tudo indica estarmos diante de serviços prestados de forma autônoma, requisitados mediante remuneração, mas sem subordinação. Perceba-se, nesse sentido, que em nenhum momento as testemunhas fizeram menção à direção dos serviços de escolta pela AMBEV, mas somente que um suposto empregado da empresa (no caso, o Sr. Paulo) entrava e contato com o Sr. Elias, Cabo da PM, quando precisava dos serviços de escolta, e que este, por sua vez, ligava para alguns colegas, de acordo com as folgas de cada um deles na Polícia, para que acompanhassem determinadas rotas de entrega de mercadorias (v. fls. 355). Destarte, concluo que, na verdade, o que existia era uma espécie de "sociedade" entre o Sr. Elias e os demais componentes da equipe de escolta, dentre os quais se inseria o reclamante, e que, se a AMBEV contratava tais serviços, esta o fazia como simples "cliente", e não como empregadora. E não se diga, também, que existia na hipótese uma pessoalidade apta a configurar o alegado contrato de trabalho entre as partes. Afinal, como destacou a testemunha Luís Henrique Silva (v. fls. 355), o serviço de escolta dependia da folga de cada um da equipe, o que, para nós, significa que os seguranças, quando não tinham disponibilidade para realizar as escoltas, podiam ser substituídos por outros colegas. Isso quebraria, portanto, o caráter personalíssimo do contrato, pois o liame empregatício somente se firma com uma única pessoa, que não pode ser substituída por outra na realização de suas atividades, salvo em circunstâncias excepcionais.

Essa conclusão, registre-se, somente se reforça pela declaração do reclamante às fls. 353 , no sentido de que na hipótese da impossibilidade de não poder acompanhar a rota, tinha que indicar outro membro da equipe para fazer. Tal afirmação, diga-se de passagem, não perde sua força por ser o reclamante "leigo sob o ponto de vista jurídico", vez que, na instrução processual, o que se investiga são fatos, para, depois aplicar-se o direito ao caso concreto. Sendo assim, entendo que a circunstância de não ter o obreiro formação jurídica não significa que, em razão disso, não entenderia o sentido de 
suas afirmações, mormente se levado em conta que, no caso, o reclamante é Policial Militar, com plenas condições de discernimento. Ademais, tenho que o simples fato de ter o autor registrado, sem maiores observações (no sentido por exemplo, da excepcionalidade dessas situações), que poderia ser substituído por outro membro da equipe é suficiente para descaracterizar o caráter intuito personae do pacto. Ora, se o próprio laborista destaca essa possibilidade, pouco importa se isso ocorreu, ou, se ocorreu, com que frequência isso aconteceu, vez que a simples permissão, por parte do tomador de serviços, para que isso ocorra configura possibilidade de substituição intermitente, circunstância que torna impessoal e fungível a figura específica do trabalhador enfocado, e descaracteriza a relação empregatícia.

Ressalte-se, por oportuno, que nada importa para relativizar a pessoalidade exigida na situação a circunstância de ser o reclamante policial militar, já que todos são iguais perante a lei, sem distinções de qualquer natureza (art. $\underline{5^{\circ}}$, caput, da Constituição Federal), de forma que não se afigura razoável, no tocante ao preenchimento dos requisitos fático-jurídicos para a configuração da relação de emprego, distinguir policiais de cidadãos comuns. Por fim, friso que nem mesmo a aplicação da Súmula $\underline{331}$ do TST pode justificar a condenação das reclamadas no pagamento de verbas trabalhistas ao autor, seja direta ou subsidiariamente. Isso porque, como já registrado, não existe qualquer contrato de emprego na situação, seja do autor com as reclamadas, seja deste com o Sr. Elias, que o obreiro alega ter sido seu chefe. Dessarte, tenho por ausentes, no caso, os seguintes elementos básicos para a ocorrência da terceirização trabalhista, quais sejam, um ente intermediário, que fornece serviços ao tomador (já que o Sr. Elias, como visto, não parece ser empregador de ninguém, mais se aproximando da figura de um "sócio" dos "seguranças") e um empregado terceirizado (pois o autor não era empregado do Sr. Elias ou da transportadora "Penha"). Logo, claramente equivocada é a tese obreira de que, sendo o Cabo Elias pessoa física, deveria ser considerado um terceiro na relação de trabalho, de maneira que, não tendo ele condições financeiras de arcar com o débito trabalhista decorrente do pacto, o alegado vínculo de emprego se formaria diretamente com as reclamadas. Afinal, em nenhum momento a Súmula $\underline{331}$ do TST1 dispõe que a situação financeira do intermediador de mão de obra faz formar o liame empregatício diretamente com o tomador, somente ocorrendo esse efeito, segundo o inciso I do mencionado verbete, nas hipóteses de terceirização ilícita, o que não é o caso. Ademais, não se poderia admitir a responsabilização do tomador pelo pagamento de verbas trabalhistas se o trabalhador sequer é empregado do intermediador.

Ex positis, não havendo relação de emprego entre reclamante e reclamadas que justifique o acolhimento do pleito autoral, nego provimento ao recurso 
ordinário e mantenho intocada a decisão de primeiro grau.

A C Ó R D A O Por tais fundamentos, ACORDAM os Desembargadores da Segunda Turma do Tribunal Regional do Trabalho da $16^{\text {a }}$ Região, por unanimidade, conhecer do recurso e, no mérito, negar-lhe provimento, para manter inalterada a decisão de primeiro grau. 


\section{PROCESSO TRT/15 ${ }^{\text {a }}$ REGIÃO No 00901-2007-007-15-00-9 \\ ORIGEM: $1^{\text {a }}$ VARA DO TRABALHO DE AMERICANA \\ JUÍZA SENTENCIANTE: DANIELLE BERTACHINI MONTELEONE}

\section{VÍNCULO EMPREGATÍCIO. SUBORDINAÇÃO RETICULAR . CONFIGURAÇÃO}

Dá-se a chamada subordinação reticular quando, não obstante o laborista tenha um controle relativo sobre suas funções, de forma supostamente autônoma, não detém a mesma autonomia com relação ao aspecto econômico da atividade empresarial. $\mathrm{Na}$ dúvida entre o trabalho dito "autônomo-dependente" e o empregado clássico, a boa regra de hermenêutica aconselha a não reduzir o potencial expansivo e protetivo do direito do trabalho.

Nestas condições, com a existência simultânea dos demais elementos caracterizadores da relação de emprego, a saber; onerosidade, pessoalidade e habitualidade, deve-se reconhecer o vínculo empregatício, com a conseqüente descaracterização de outras formas de relação de trabalho. Recurso da ré a que se nega provimento.

Inconformados com a r. sentença de origem de fls.110/119, complementada em sede de embargos de declaração de fls.131/132, que julgou PROCEDENTE EM PARTE a reclamação trabalhista, recorrem os reclamados às fls.145/155, alegando, preliminarmente, inépcia da inicial, com a respectiva extinção do feito. Alega ainda que a decisão proferida pelo MM. Juiz Monocrático estaria incorrendo em decisão extra petita em razão de não haver, no âmbito da petição inicial, pedido de nulidade do contrato de parceria celebrado entre as partes.

No mérito, insurge-se contra o reconhecimento do vínculo empregatício, alegando que as provas carreadas nos autos estariam demonstrando a ausência de subordinação por parte do reclamante e que este teria sido contratado na modalidade autônoma. Pugna, nesse sentido, pelo afastamento do vínculo reconhecido e a consequente improcedência das verbas trabalhistas deferidas.

Por fim, pugna pela improcedência dos honorários advocatícios.

Contra-razões do reclamante às fls.162/166, pela manutenção do 
julgado.

O presente feito não foi remetido ao Ministério Público do Trabalho, tendo em vista o disposto nos artigos 110 e 111 do Regimento Interno deste Egrégio Regional.

É o relatório.

\section{O T O}

Conheço do recurso ordinário interposto, uma vez que preenchidos os pressupostos processuais de admissibilidade.

\section{Da inépcia da inicial}

Alegam os reclamados, em caráter preliminar, inépcia da inicial decorrente da ausência de pedido expresso relativo à existência de vínculo empregatício.

Entretanto, na seara do direito processual do trabalho, não se aplica, quanto à causa de pedir, a teoria da substanciação (art. 282, III, do CPC), já que na CLT existe dispositivo próprio; vale dizer, o parágrafo $1^{\circ}$ do art. 840, da CLT, que exige apenas a exposição dos fatos de que resulte o dissídio, descartando o rigorismo da processualística civil.

Presentes tais requisitos, não há que se falar em inépcia da inicial, devendo ser afastada a preliminar arguida.

\section{Da decisão extra petita}

Ainda em caráter preliminar, alegam os reclamados que teria restado caracterizada como ultra petita a decisão que anulou o contrato de parceria, reconhecendo o vínculo empregatício entre as partes, sem que houvesse pedido expresso nesse sentido.

Da análise da inicial, fls.2, segundo parágrafo, constata-se o

enunciado: “ O reclamante foi contratado pelos reclamados no dia 01 de abril de 2006 para exercer as funções de cirurgião dentista em clínica dentária de propriedade destes...Entretanto, com claro intuito de burlar a legislação trabalhista e os direitos do. reclamante, os reclamados exigiram-lhe a assinatura do CONTRATO DE PARCERIA COMERCIAL E DE SERVIÇOS”. Por consequência, não foi registrado nem recebeu nenhuma verba trabalhista".(g.n)

Ora, a lógica mais elementar nos compele a concluir que está implícito, na afirmação acima, que o reclamante alega a existência de uma relação de 
emprego ocultada por um contrato de "parceria", passível de nulidade, a fim de que se revele a verdadeira natureza da relação de trabalho existente entre as partes.

Portanto, padece da falta de qualquer fundamento a alegação ventilada pela parte em suas razões recursais, concernentes à existência de decisão extra petita. Rejeita-se, pois, a preliminar argüida.

\section{Do vínculo empregatício}

Insistem os reclamados na tese de que inexistia relação de emprego junto ao reclamante, pugnando pela validade do contrato de parceria comercial.

Todavia, razão não lhes assiste.

Destarte, restou incontroversa a presença dos principais elementos caracterizadores do vínculo empregatício, a saber: a pessoalidade, a habitualidade e a onerosidade. Entretanto, os reclamados alegam fato modificativo à relação, a saber, a autonomia do reclamante para exercer o seu trabalho, inexistindo subordinação.

Para o reconhecimento da natureza da relação desenvolvida pelo autônomo, é necessário bastante cautela, pois é muito tênue a distinção entre o trabalhador subordinado e o autônomo, sendo que, segundo a maioria dos doutrinadores, a distinção é feita basicamente pelo elemento subordinação, porque a atividade do empregado é dirigida pelo empregador enquanto o autônomo organiza e desenvolve suas atividades de acordo com seus próprios critérios, assumindo os riscos de sua execução.

$\mathrm{Na}$ lição do Ministro Maurício Godinho Delgado (in "Curso de Direito do Trabalho", LTr, 6 $6^{\text {a }}$ edição), subordinação é o "elemento principal de diferenciação entre a relação de emprego e o segundo grupo mais relevante de fórmulas de contratação de prestação de trabalho no mundo contemporâneo...(pg.301). Acrescenta: "subordinação é um fenômeno jurídico derivado do contrato estabelecido entre trabalhador e tomador de serviços, pelo qual o primeiro acolhe o direcionamento objetivo do segundo sobre a forma de efetuação da prestação do trabalho” (pg.303).

Conforme muito bem colocado no âmbito da decisão a quo, o reclamante prestava os seus serviços para uma clínica especializada em tratamentos odontológicos, com outras sedes de prestação de serviços, onde submetia-se a uma forma de subordinação denominada reticular, de natureza estrutural, onde o laborista não podia exercer suas funções sem a atividade empresarial encabeçada pelos reclamados.

No novo contexto mundial, com as transformações no cenário econômico e social, o elemento da subordinação ganhou novos contornos, caracterizando a figura do trabalho "autônomo-dependente". Trata-se daquela situação em que o trabalhador 
supostamente autônomo, mas habitualmente inserido na produção alheia, a despeito de ter controle relativo sobre o próprio trabalho, não detém nenhum controle sobre a atividade econômica. Tal situação demonstra a diferença entre subordinação estrutural e reticular, posto que, se a prestação desse trabalho ingressa na empresa através de um contrato de prestação de trabalho autônomo, mas adere às atividades dessa empresa, a disposição do trabalho subsiste pelo tomador de serviços, na medida em que a impessoalidade da disposição do trabalho não afasta a circunstância de ter sido contratado para desenvolver atividade e não resultado.

Da análise da prova testemunhal colhida (fls.54/57), verifica-se que a própria testemunha do reclamado, Francisco de Assis Inaimo, admite "que os reclamados tem poder de fiscalização quanto ao trabalho realizado e cobrança ao dia de atendimento..." (fls.55).

Tal fator, unido a outros aspectos relevantes, como o fato dos depósitos dos faturamentos diários serem efetuados em conta corrente dos reclamados, demonstra a existência de uma forma de subordinação reticular, razão pela qual resta caracterizada a alegada relação de emprego entre as partes.

Logo, não há que se falar em reforma da sentença prolatada no aspecto, devendo permanecer inalterada a condenação dos reclamados em todas as verbas trabalhistas decorrentes do reconhecimento de relação de emprego.

Dos honorários advocatícios

Pleiteiam, igualmente, os reclamados, a reforma da sentença quanto à condenação no pagamento de honorários advocatícios.

Razão lhes assiste.

Os honorários advocatícios são devidos, nesta Especializada, quando a parte estiver assistida pelo sindicato de classe e for beneficiária da assistência judiciária, nos termos da Lei 5.584/70 e da Súmula 219 do C. TST.

Não tendo a parte reclamante cumprido um dos requisitos, não faz jus a esta verba, razão pela qual dou provimento ao recurso dos reclamados para excluir da sentença a condenação em honorários advocatícios, nos termos da fundamentação.

Diante do exposto, decido: conhecer do recurso ordinário interposto pelo reclamante para, afastando as preliminares argüidas, DAR-LHE PARCIAL PROVIMENTO para excluir da sentença a condenação nos honorários advocatícios, mantendo, no mais, a $\mathrm{r}$. sentença de origem por seus próprios e jurídicos fundamentos. 
Para fins recursais, rearbitro o valor das custas em $\mathrm{R} \$ 300,00$.

CARLOS ROBERTO DO AMARAL BARROS

Desembargador Relator 
PROCESSO TRT 15 ${ }^{\mathrm{a}}$ REGIÃO $\mathrm{N}^{\circ}$. 0054300-56.2009.5.15.0129

RECURSO ORDINÁRIO - RITO ORDINÁRIO

JUIZA SENTENCIANTE: CAMILA CERONI SCARABELLI

REPRESENTAÇÃO COMERCIAL AUTÔNOMA X VENDEDOR EMPREGADO - TEORIA DA INSERÇÃO OU SUBORDINAÇÃO ESTRUTURAL - VÍNCULO EMPREGATÍCIO CARACTERIZADO. O que distingue o representante comercial do vendedor empregado é exatamente a autonomia com que aquele exerce as suas atividades, o que sempre é revelado por um contexto fático que engloba carteira própria de clientela, não exigência do representado de metas de vendas, liberdade de abrir cadastros de novos e excluir clientes, dever de prestar contas, receber apenas orientação do representado, sem, contudo, acompanhamento de supervisor etc. Enfim, um conjunto de circunstâncias que revelam ter o representante comercial uma clientela própria para oferecer ao representado, em prol de quem efetuará negócios comerciais. $\mathrm{Na}$ hipótese, à míngua de prova segura que à recorrente competia produzir, resta evidenciada a existência de plena subordinação jurídica, elemento diferenciador entre o representante comercial autônomo e o vendedor regido pela CLT, haja vista que em ambos os contratos se encontram presentes os requisitos da pessoalidade, não-eventualidade e onerosidade. É a chamada "subordinação estrutural", conforme classificação nova que na doutrina de Lamarca era a inserção da atividade do trabalhador nos objetivos sociais da empresa. Neste contexto, indubitável que a prestação de serviços dava-se de forma subordinada, com os demais elementos dos artigos $2^{\circ}$ e $3^{\circ}$ da CLT. Recurso da ré desprovido.

DANOS MORAIS - AUSÊNCIA DE PROVA - NÃO CONFIGURAÇÃO. O sucesso da ação que tenha por objeto indenização por dano moral exige prova cabal e robusta da violação à imagem, à honra, à liberdade, ao nome e que a 
conduta patronal que acarrete dor, sofrimento e tristeza, ou seja, ao patrimônio imaterial do trabalhador. E mais, que este contexto decorra: a) ato comissivo ou omissivo; b) que tenha nexo causal; c) a culpa do empregador. No caso, o autor se limita a narrar na petição inicial que a não anotação do registro do contrato de trabalho em CTPS fez com que deixasse de receber direitos básicos inerentes à relação de emprego, havendo, assim, abuso de direito e agressão a dignidade e à honra do trabalhador. Ocorre que dissabores vivenciados no curso da relação de emprego não são suficientes para autorizar o reconhecimento de dano moral e o conseqüente deferimento da indenização pretendida. Logo, se não há nos autos provas cabais dos supostos constrangimentos mencionados na inicial, não se vislumbra que os transtornos pessoais enfrentados possam gerar para o empregado uma indenização por dano moral. Recurso Ordinário do reclamante conhecido e desprovido.

Inconformadas com a r. sentença de fls. 93/107, complementada às fls. 143/144-verso, que julgou os pedidos PROCEDENTES EM PARTE, recorrem as partes.

O ReCLAMANTE sustenta que a reclamada confessou em audiência que concedia aos seus empregados convênio médico. Assim, tem direito ao recebimento de reembolso relativo a todo o período laboral. Deseja ainda a revisão do julgado em relação ao sobreaviso e indenização por danos morais (fls. 116/123).

A RECLAMADA alega que o juízo a quo, ao encerrar a instrução probatória sem permitir a produção de prova testemunhal, incorreu em nulidade processual por cerceamento de defesa, haja vista que a produção da prova era essencial à comprovação dos fatos alegados na contestação. Assim, requer seja declarada a nulidade da sentença, para que seja determinada a baixa dos autos à origem, com a reabertura da instrução processual para que possa ser realizada a prova testemunhal. Aduz que o juízo sentenciante incorreu em julgamento extra petita ao condená-la ao pagamento de indenização substitutiva do seguro-desemprego e cestas básicas, posto que não consta dos autos pedidos nesses sentidos. No mérito, quanto ao vínculo empregatício, insiste que o autor não foi empregado da empresa, mas sim representante comercial autônomo, sem exclusividade e subordinação jurídica, e realizando vendas e recebendo exclusivamente 
comissões, na forma prevista na Lei 4.886/65. Em relação ao valor fixado à título de salário, assevera que era do autor, e não da empresa, o ônus de comprovar que o salário mensal pactuado era de $\mathrm{R} \$ 6.000,00$, encargo probatório do qual não se desincumbiu, devendo, portanto, a r. sentença ser revista também nesse ponto. Por fim, requer a revisão do julgado quanto à determinação de expedição de ofício e em relação a aplicação de multa por litigância de má-fé (fls. 148/160).

Contrarrazões às fls. 179/184 e 194/200.

Não houve remessa ao MPT (cf. regimento interno deste TRT).

É O RELATÓRIO.

V O T O

ADMISSIBILIDADE

Recursos tempestivos (fls. 113 e 116-reclamante; e fls. 145 e 148-reclamada) e representações regulares (fl. 11-reclamante; e fls. 75/76-reclamada).

Custas e depósito recursal a contento (fls. 161/162).

ConHEÇO, eis que preenchidos os pressupostos de

admissibilidade.

Por contemplar questão preliminar, o recurso ordinário da reclamada será preferencialmente analisado.

\section{I - RECURSO ORDINÁRIO DA RECLAMADA}

\section{I.1 - P R E L I M I N A R M E N T E}

I.1.1 - DA NULIDADE PROCESSUAL POR CERCEAMENTO AO DIREITO DE PRODUÇÃO DE PROVA

Alega a reclamada, ora primeira recorrente, que o juízo a quo, ao encerrar a instrução probatória sem permitir a produção de prova testemunhal, incorreu em nulidade processual por cerceamento de defesa, haja vista que a produção da prova era essencial à comprovação dos fatos alegados na contestação. Assim, requer seja declarada a nulidade da sentença, para que seja determinada a baixa dos autos à origem, com a reabertura da instrução processual para que possa ser realizada a prova testemunhal.

SEM RAZÃO.

No caso, foi designada audiência UNA, tendo a reclamada sido expressamente notificada de quanto a necessidade de comparecimento pessoal, além de trazer suas testemunhas independentemente de notificação (vide fl. 70).

Com efeito, a regra no processo do trabalho é no sentido de que as próprias partes devem conduzir suas testemunhas à audiência independentemente de 
notificação, a teor do artigo 825 da CLT. Em assim sendo, assim, somente na recusa da(s) testemunha(s) em comparecer espontaneamente é que a parte interessada requererá sua notificação, quando então estarão obrigadas ao comparecimento, sob pena de condução coercitiva.

Aqui, conforme se verifica do conteúdo da Ata de Audiência UNA, a reclamada não alegou que convidou testemunha para comparecimento espontâneo e que esta tenha deixado de comparecer. De outro lado, oportunamente, não arrolou testemunha para que pudesse ser notificada pelo juízo (vide fls. 71/73).

Logo, não há que se falar em nulidade por cerceamento ao direito de produção de prova, haja vista que foi efetivamente oportunizado à reclamada $o$ direito de trazer em juízo suas testemunhas, pois o juízo a quo atuou em plena consonância com os artigos 825 e 845 da CLT.

Assim, em que pese a argumentação recursal, não se verifica o propalado cerceio probatório, uma vez que cabe o Juiz, único e real destinatário da prova, indeferir as diligências que entender inúteis, desnecessárias ou meramente protelatórias, expondo na sentença as razões que o levaram a formação de seu convencimento (artigos 130 e 131 do CPC).

Neste sentido, os ensinamentos de Wagner D. Giglio (in "Direito Processual do Trabalho", 7ª edição, Ed. LTr, 1993, pág. 241):

"A adoção do princípio inquisitório constrange o juiz a, dirigindo a instrução processual, só permitir a prova de fatos relevantes e pertinentes, recusando diligências desnecessárias e indeferindo as inúteis ou protelatórias (CPC, art. 130). Em decorrência, o juiz vedará a prova de fato que, embora relevante, não tenha interesse para a solução do litígio, isto é, seja impertinente; e vice-versa: não permitirá prova de fato que, não obstante atinente à lide, seja irrelevante ou sem importância para o seu deslinde."

Portanto, não há que se falar em cerceamento ao direito de defesa e/ou de produção de prova, pois o juízo de primeiro grau analisou de forma correta as questões de fato e de direito submetidas à sua apreciação, solucionando a lide frente às provas produzidas e ao direito material aplicável ao caso concreto, sem mácula ou violação ao artigo 832 da CLT, atendendo às formalidades dos artigos 458 do CPC e às exigências expressas no artigo 93, IX, da CRFB/88. 
Neste sentido, há o seguinte posicionamento jurisprudencial:

"Não se anula o processo quando o indeferimento da prova requerida é desnecessário, já contendo os autos os elementos necessários para a sentença. A anulação do processo com o retorno á instância é medida radical que só deve ser usada em casos extremos onde havia evidente prejuizo à parte que a requer. O processo deve ser encarado por qualquer juiz de primeira ou de Segunda instância, como um meio de solucionar, não de procrastinar os conflitos sociais." (TRT $3^{a}$ Reg.-RO04352/92 - 3 ${ }^{a}$ T- Rel. Juiz Antonio Alvares da Silva).

Logo, não ocorreu o alegado cerceamento de defesa. Rejeita-se.

\section{I.1.2 - DO JULGAMENTO EXTRA PETITA}

Aduz a recorrente que o juízo sentenciante incorreu em julgamento extra petita ao condená-la ao pagamento de indenização substitutiva do segurodesemprego e cestas básicas, posto que não consta dos autos pedidos nesses sentidos.

Ainda que cometa a sentença de eventual julgamento extrapetita, se o juízo a quo, como in casu, não se omitiu, nem deixou de apreciar a causa de pedir e o pedido originários, não enseja decreto de nulidade da sentença guerreada. Isto porque, o Tribunal pode se pronunciar sobre o pedido correto, sem supressão de grau de jurisdição, adequando a solução da lide aos limites da litiscontestatio (artigos 128 e 460 do $\mathrm{CPC}$ ), o que afasta, em definitivo, qualquer prejuízo à recorrente.

No caso, ao reverso do quanto alegado pela recorrente, consta, sim, da petição inicial pedido de indenização substitutiva do seguro-desemprego e cestas básicas (vide petição inicial - fl. 09, itens '4.7' e '5’).

Nego provimento.

\section{I.2 - N O M É R I T O}

\section{I.2.1 - DO VÍNCULO EMPREGATÍCIO}

No mérito, quanto ao vínculo empregatício, insiste a reclamada que o autor não foi empregado da empresa, mas sim representante comercial autônomo, sem exclusividade e subordinação jurídica, e realizando vendas e recebendo exclusivamente comissões, na forma prevista na Lei 4.886/65. 


\section{SEM RAZÃO.}

Vige no direito do trabalho o princípio do contrato realidade, devendo-se atentar para o que efetivamente ocorre na prestação diária de serviços, ainda que isto contrarie condições postas em contrato ao qual tenha aderido o obreiro.

É árdua a tarefa de diferenciação entre o vendedor empregado e o vendedor autônomo, pois em ambos os casos estão presentes a pessoalidade, a nãoeventualidade e a onerosidade, devendo-se tomar como traço distintivo a subordinação jurídica, que se faz presente de forma mais intensa e dominante no caso de configuração do vínculo empregatício.

Mais intensa porque não se pode olvidar que, mesmo na relação de índole autônoma, está presente pequeno grau de subordinação, o que se denota, por exemplo, da leitura do artigo 28 da Lei n. 4.886/65, que dispõe que "o representante comercial fica obrigado a fornecer ao representado, segundo as disposições do contrato $o u$, sendo este omisso, quando the for solicitado, informações detalhadas sobre o andamento dos negócios a seu cargo, devendo dedicar-se à representação, de modo a expandir os negócios do representado e promover os seus produtos".

$\mathrm{Na}$ análise de cada caso concreto deve-se desvendar qual é a verdadeira natureza da relação estabelecida entre as partes, levando-se em consideração, ainda, a presença de elementos que indiquem a ocorrência de fraude que vise a disfarçar relação de emprego como se trabalho autônomo fosse.

A contratação de representação comercial autônoma deve ser feita necessariamente por escrito para ostentar que o representante é portador de registro profissional obrigatório, por meio de inscrição no Conselho Regional, e demonstrar que o contrato contém cláusulas obrigatórias, conforme arts. $2^{\circ}$ e 27 da Lei 4.886/65. Tratando-se de atividade profissional regulamentada através de lei específica são exigidas certas formalidades legais para a sua caracterização, embora estes requisitos, por si só, possam não ser suficientes para tal.

Assim, para a caracterização da prestação de serviços de forma autônoma, na qualidade de representante comercial, mister se faz a prova do cumprimento dos requisitos da Lei $\mathrm{n}^{\circ} 4.886 / 65$, de natureza eminentemente objetiva. Sem prova, torna-se inviável admitir a representação comercial autônoma.

Por outro lado, o fato que distingue o representante comercial e o vendedor empregado é exatamente a autonomia com que aquele exerce a sua atividade, $o$ que sempre é revelado por um contexto fático. Engloba carteira própria de clientela, inexistência de rota a cumprir, sem metas de vendas a ser atingidas, além de liberdade para abertura de cadastros de novos clientes. Enfim, um conjunto de circunstâncias que revelam 
ter o representante comercial uma clientela própria para oferecer ao representado, para quem efetuará negócios comerciais.

Não prova, a cargo da reclamada, que demonstre que tais encargos ficassem por conta do reclamante.

Ressalte-se que mera ausência de registro no Conselho Regional dos Representantes Comerciais, exigido pela Lei nº 4.886/64, não acarreta, por si só, o reconhecimento do vínculo empregatício, sendo imprescindível o cumprimento de todos os requisitos exposto no artigo $3^{\circ}$ da CLT, principalmente a subordinação.

A CLT estabelece, em seu art. 30, que: "Considera-se empregado toda pessoa física que prestar serviço de natureza não eventual a empregador, sob a dependência deste e mediante salário".

Logo, só há como se reconhecer da existência de vínculo de emprego quando presentes os elementos necessários à sua formação (art. $3^{\circ}$ da CLT), como a pessoalidade, a não eventualidade, a onerosidade e a subordinação.

No caso dos autos, a ré negou a relação jurídica de emprego, mas admitiu a prestação de serviços por parte do autor. Assim, atraiu para si o encargo probatório, nos termos dos artigos 818 da CLT e 333, II, do CPC, haja vista que alegou fato impeditivo do direito do autor.

Ocorre, contudo, que além de a reclamada não comprovar nos autos a existência de contrato escrito com o autor expressamente prevendo a condição de representante comercial, e ainda de não comprovar seu registro no Conselho da categoria, não produziu outras provas que pudessem dar suporte às suas alegações de modo a suprir os requisitos formais já destacados.

Logo, à míngua de prova segura que à recorrente competia produzir, resta evidenciada a existência de plena subordinação jurídica, elemento diferenciador entre o representante comercial autônomo e o vendedor regido pela CLT, haja vista que em ambos os contratos se encontram presentes os requisitos da pessoalidade, não-eventualidade e onerosidade.

Também como indicadores distintivos (autêntico vendedor autônomo $\mathrm{x}$ vendedor empregado), sobressaem-se o fato de o reclamante ter exercido função vinculada às atividades normais desenvolvidas pela ré e adstrito aos métodos de vendas, resultando evidenciada a subordinação jurídica, razão pela qual a suposta existência de contrato de prestação de serviço autônomo serviu apenas para mascarar a verdadeira relação jurídica havida.

Segundo o eminente Ribeiro de Vilhena, "autônomo é o trabalhador que desenvolve sua atividade com organização própria, iniciativa $e$ 
discricionariedade, além da escolha do lugar, do modo, do tempo e da forma de execução", o que, segundo o contexto probatório não ocorria na relação jurídica mantida entre as partes.

Destarte, conforme exposto pelo juízo a quo, tem-se que houve prestação de serviços por parte do autor à ré de forma continuada, sob dependência e mediante remuneração, encontrando-se presentes os requisitos previstos no artigo $3^{\circ}$ da CLT, necessários para a caracterização do vínculo de emprego.

Reconhecida a relação jurídica de emprego, a condenação ao pagamento das verbas vindicadas na petição inicial é mera conseqüência, diante do princípio da continuidade do contrato de trabalho.

Assim sendo, nego provimento ao recurso ordinário da reclamada.

\section{I.2.2 - DO SALÁRIO E COMISSÕES}

Em relação ao valor fixado à título de salário, assevera a recorrente que era do autor, e não da empresa, o ônus de comprovar que o salário mensal pactuado era de $\mathrm{R} \$ 6.000,00$, encargo probatório do qual não se desincumbiu, devendo, portanto, a r. sentença ser revista também nesse ponto.

SEM RAZÃO.

Em relação ao valor do salário mensal fixo, os extratos encartados às fls. 17/23, não desconstituídos pela ré mediante a produção de prova em sentido contrário, demonstram o recebimento de salário mensal no importe de $\mathrm{R} \$ 6.000,00$.

No que tange às comissões, conforme corretamente exposto pelo juízo a quo, a demandada é confessa, pois o preposto, em depoimento pessoal, confessou desconhecer o percentual do valor da comissão a ser paga pela venda concretizada.

De tal sorte, em ambos os casos, prevalecem os valores indicados na petição inicial, quais sejam, salário de R \$ 6.000,00/mês + comissão de $10 \%$ do lucro obtido com a venda do frete internacional.

Nego provimento.

\section{I.2.3 - DA EXPEDIÇÃO DE OFÍCIOS}

Verificadas inúmeras irregularidades quanto aos direitos trabalhistas, correta a determinação de expedição de ofícios aos órgãos competentes, para as providências que entenderem cabíveis.

Nego provimento. 


\section{I.2.4 - DA MULTA POR LITIGÂNCIA DE MÁ-FÉ}

O litigante de má-fé (autor ou réu) é sempre passível de sanção, inclusive no processo do trabalho, por aplicação subsidiária dos artigos 14 a 18 do CPC, que contemplam normas gerais de ética no processo, não dispensa, ao contrário, o bom senso aconselha, uma dose de razoabilidade na sua imposição.

O que a lei quer punir, e nisso o Juiz deve sempre estar vigilante, é o dolo, o abuso em se utilizar do processo, trazendo a juízo simulação de lide ou de elementos de defesa e de recurso inexistentes e/ou forjados, sem obtenção de vantagem, mas apenas para causar dano à parte contrária. Isto quando ficar razoavelmente provado. Assim, a penalidade pecuniária prevista no CPC é apenas uma das faculdades das que dispõe o julgador como meio eficaz de reprimir expedientes manifestamente procrastinatórios, prejudicando não só a parte contrária diretamente interessada no feito, mas a todo corpo social com um incontável número de demandas perpetuadas por garantias processuais astuciosamente utilizadas.

No presente caso, de fato, da análise do conteúdo dos embargos declaratórios, denota-se que a ré desejou a reapreciação de matéria que já havia sido decidida por parte do juízo a quo, o que é vedado por lei.

Nego provimento.

\section{II - RECURSO ORDINÁRIO DO RECLAMANTE II.1 - DO REEMBOLSO DO CONVÊNIO MÉDICO}

Sustenta o reclamante, ora segundo recorrente, que a reclamada confessou em audiência que concedia aos seus empregados convênio médico. Assim, tem direito ao recebimento de reembolso relativo a todo o período laboral.

COM RAZÃO.

Em depoimento pessoal, o preposto da ré confessou que (fl. 73):

“... os funcionários recebem cesta básica e convênio médico; que o reclamante não recebia esses benefícios. ... “

Com efeito, o artigo 348 do CPC, aplicado por força do artigo 769 da CLT, é claro ao dispor que há confissão quando a parte admite a verdade de um fato contrário ao seu interesse e favorável ao adversário. Já o artigo 350 do mesmo estatuto adjetivo preceitua que a confissão judicial faz prova contra o confitente.

Ensina Humberto Theodoro Júnior que ('in' Curso de Direito Processual Civil - Volume I, Editora Forense - 12a Edição - pág. 428). 
"Para bem se alcançar o conceito desse meio de prova, deve-se recorrer à definição extraída dos clássicos ensinamentos de João Monteiro e Lessona, aproximadamente, nos seguintes termos: confissão é a declaração, judicial ou extrajudicial, provocada ou espontânea, em que um dos litigantes, capaz e com ânimo de se obrigar, faz da verdade, integral ou parcial, dos fatos alegados pela parte contrária, como fundamentais da ação ou da defesa".

Aqui, não foi produzido prova que suplantasse a ficta confessio, de sorte que deve prevalecer o entendimento de que se os demais funcionários eram beneficiados com o convênio medico, o autor, também na condição de empregado, também, por extensão, tem direito ao recebimento do benefício em questão.

Logo, provejo o apelo do reclamante, para condenar a reclamada a indenizar ao autor o valor de $\mathrm{R} \$ 289,00$ por mês trabalhado à título de reembolso de valores gastos com convênio médico.

\section{2 - DO SOBREAVISO}

Requer ainda o reclamante no recebimento do pagamento de adicional de sobreaviso, sob o argumento de que a empresa forneceu aparelho celular para que ficasse ligado em período integral, para o atendimento aos clientes.

SEM RAZÃO.

Nos termos do $\S 2^{\circ}$ do art. 244 da CLT, as horas de sobreaviso caracterizam-se pelo fato do empregado ficar em sua residência, aguardando ser chamado para o serviço.

O uso de telefone móvel obviamente que não restringe o deslocamento do empregado e nem fere a disponibilidade de tempo, e, assim, menos ainda, exige que permaneça em casa aguardando chamado para o trabalho.

Assim, ao utilizar-se do aparelho celular, o empregado não precisava manter-se necessariamente em sua residência, aguardando o chamado para serviço, podendo deslocar-se normalmente, dentro do raio de alcance do aparelho, o que torna indevida a aplicação analógica do mencionado dispositivo legal, ainda que prestasse serviço como assistente técnico de empresa do ramo de energia.

Nesse sentido, aliás, tem decidido o TST:

“AGRAVO DE INSTRUMENTO. SOBREAVISO. USO DE TELEFONE CELULAR. O uso de telefone celular, a exemplo 
do aparelho de BIP, não configura o regime de sobreaviso, pelo fato de o empregado não permanecer em sua casa aguardando o chamado para o serviço, podendo, pois, deslocar-se livremente ou até dedicar-se a outra atividade em seu periodo de descanso. Nesse diapasão, esta Corte vem se inclinando em aplicar, analogicamente, a Orientação Jurisprudencial n ${ }^{\circ} 49$ da SBDI-1 ao empregado portador de aparelho celular, como na hipótese dos autos. Agravo de instrumento desprovido. Processo: AIRR - 77647/2003-900-02-00.3 Data de Julgamento: 10/12/2008, Relator Ministro: Vantuil Abdala, $2^{a}$ Turma, Data de Publicação: DJ 06/03/2009.

Nego provimento.

\section{II.3 - DOS DANOS MORAIS}

Por fim, insiste o reclamante na condenação da reclamada ao pagamento de indenização por danos morais, diante da falta de registro em CTPS.

SEM RAZÃO.

A indenização por danos morais tem por fundamento uma lesão a um bem juridicamente tutelado que não pode se exprime em valores econômicos, porque se refere aos aspectos mais íntimos da personalidade humana, como a honra, a imagem. A tutela jurídica destes bens não suscetíveis de valor econômico está expressa, em nosso ordenamento jurídico, na própria Constituição Federal, que não só proclama a "dignidade da pessoa humana" como fundamento do Estado Democrático de Direito (artigo 1. ${ }^{\circ}$, III), como preceitua serem invioláveis "a intimidade, a vida privada, a honra e a imagem das pessoas, assegurado o direito a indenização pelo dano material ou moral decorrente de sua violação" (artigo $\left.5^{\circ}, \mathrm{X}\right)$.

A doutrina já consagrou uma definição e uma classificação para o dano moral, melhor dotada de consensualidade, encontrando-se de certa forma compendiada na lição da insigne MARIA HELENA DINIZ, em seu festejado "Curso de Direito Civil Brasileiro" (São Paulo: Saraiva, 2002, $7^{\circ}$ vol., 16. ed., p. 83), quando discorre sobre a responsabilidade civil, assim traduzida:

"c.3.2. Dano moral direto e indireto. O dano moral direto consiste na lesão a um interesse que visa a satisfação ou gozo de um bem jurídico extrapatrimonial contido nos direitos da personalidade (como a vida, a integridade corporal, a liberdade, 
a honra, o decoro, a intimidade, os sentimentos afetivos, a própria imagem) ou nos atributos da pessoa (como o nome, a capacidade, o estado de família). O dano moral indireto consiste na lesão a um interesse tendente à satisfação ou gozo de bens jurídicos patrimoniais, que produz um menoscabo a um bem extrapatrimonial, ou melhor, é aquele que provoca prejuízo a qualquer interesse não patrimonial, devido a uma lesão a um bem patrimonial da vítima. Deriva, portanto, do fato lesivo a um interesse patrimonial. P. ex.: perda de coisa com valor afetivo, ou seja, de um anel de noivado."

Assim, o dano moral encontra fundamento legal nas disposições contidas no artigo $5^{\circ}, \mathrm{V}$ e $\mathrm{X}$, da Constituição Federal, sendo considerado aquele proveniente da violação dos direitos individuais de cada cidadão relativamente à sua intimidade, privacidade, honra e imagem, de natureza íntima e pessoal em que se coloca em risco a própria dignidade da pessoa humana, diante do contexto social em que vive. $\mathrm{O}$ artigo 186 do Código Civil vigente, em correspondência ao art. 159 do Código Civil de 1916, consagra a regra de que todo aquele que causa dano a outrem é obrigado a repará-lo. Atento ao que dispõe o mencionado dispositivo, constata-se serem quatro os pressupostos da responsabilidade civil, quais sejam: ação ou omissão, culpa ou dolo, relação de causalidade e o dano experimentado pela vítima.

No caso, o autor se limita a narrar na petição inicial que a não anotação do registro do contrato de trabalho em CTPS fez com que deixasse de receber direitos básicos inerentes à relação de emprego, havendo, assim, abuso de direito e agressão a dignidade e à honra do trabalhador.

Nunca é demais acrescentar que a reparação de danos morais só tem cabimento, portanto, quando houver ofensa a direitos da personalidade humana. Neste sentido, é interessante colacionar excertos de acórdão do Egrégio Tribunal de Justiça do Rio de Janeiro ${ }^{104}$ em decisão prolatada em autos de apelação cível em que foram apelantes Ney Matogrosso, Milton Nascimento e Caetano Veloso e apelados Bloch Editores S/A e outra proclamou com profundo acerto:

“I. Os direitos da personalidade estão agrupados em direitos à integridade física (direito à vida, direito sobre o próprio corpo; e direito ao cadáver) e direitos à integridade moral (direito à

104. Decisão proclamada pelos desembargadores da 1 Câmara Cível do TJRJ, sendo relator o Des. Carlos Alberto Menezes Direito, j. em 19.11.1991, nos autos de apelação Cível, em que são apelantes Ney de Souza Pereira e outros e apelados Bloch Editores S/A e outra, in RDP 185/198. 
honra; direito à liberdade, direito ao recato; direito à imagem; direito ao nome; direito moral do autor). A Constituição Federal de 1988 agasalhou nos incisos $V$ e $X$ do artigo $5^{\circ}$ os direitos subjetivos privados relativos à integridade moral.

II. Dano moral. Lição de Aguiar Dias: o dano moral é o efeito não patrimonial da lesão de direito e não a própria lesão abstratamente considerada. Lição de Savatier: dano moral é todo sofrimento humano que não é causado por uma perda pecuniária. Lição de Pontes de Miranda: nos danos morais a esfera ética da pessoa é que é ofendida; o dano patrimonial é o que, só atingindo o devedor como ser humano, não the atinge o patrimônio:

III. O Ser humano tem uma esfera de valores próprios que são postos em sua conduta não apenas em relação ao Estado, mas, também, na convivência com os seus semelhantes. Respeitamse, por isso mesmo, não apenas aqueles direitos que repercutem no seu patrimônio material, mas aqueles direitos relativos aos seus valores pessoais, que repercutam nos seus sentimentos. Não é mais possivel ignorar esses cenários em uma sociedade que se tornou invasora porque reduziu distâncias, tornando-se pequena e, por isso, poderosa na promiscuidade que propicia. Dai ser necessário enfatizar as ameaças a vida privada que nasceram no curso da expansão e desenvolvimento dos meios da comunicação de massa."

E, ao final da decisão, a Corte proferiu o seguinte julgamento:

"Assim, entende a Corte que o apelante dever ser indenizado pelo dano moral que sofreu em decorrência do ato ilícito positivo das apeladas, violador do inciso $X$, do artigo $5^{\circ} d a$ Constituição Federal".

Logo, quando não há nos autos provas suficiente quanto á prática de atos discriminatórios, ou que tenha colocado o reclamante em situação vexatória, humilhante e/ou dos constrangimentos mencionados na inicial, não se vislumbra que os transtornos pessoais enfrentados no curso da relação de emprego possam gerar para $o$ empregador uma indenização por dano moral.

Nego provimento.

Por tais Fundamentos, decide-se CONHECER DOS RECURSOS 
ORDINÁRIOS e, no mérito: 1) - DAR PARCIAL PROVIMENTO AO RECURSO do REClAMANTE, para condenar a reclamada a indenizar ao autor o valor de $\mathrm{R} \$ 289,00$ por mês trabalhado à título de reembolso de valores gastos com convênio médico, nos termos da fundamentação, integrante do presente dispositivo. 2) - Negar Provimento ao ReCURSO da ReClamada. Mantenho íntegra em seus demais aspectos a $\mathrm{r}$. sentença, por seus próprios e jurídicos fundamentos.

DESEMBARGADOR JOSÉ ANTONIO PANCOTTI RELATOR 
SUPERSUBORDINAÇÃO. DANO PESSOAL. NÃO PAGAMENTO DE SALÁRIOS E DE VERBAS RESCIÓRIAS. INDENIZAÇÃO DEVIDA. Ao ser forçado a deixar o emprego, por não ter recebido salário, e sequer receber as verbas rescisórias, o reclamante foi vítima duas vezes de dano à sua pessoa, pois o desrespeito deliberado e inescusável de direitos trabalhistas conduz o trabalhador a uma condição de sub-cidadania, já que o Direito do Trabalho, conforme expressa o Min. Maurício Godinho, é o marco regulatório mínimo da cidadania (ou o patamar mínimo civilizatório). Não cumprir direitos trabalhistas de forma grosseira, intencional, portanto, não é mero "inadimplemento contratual". Trata-se, isto sim, de uma agressão ao cidadão trabalhador e, porque não dizer, a toda a sociedade. O Direito do Trabalho é o retorno de natureza sócio-econômica que se confere ao trabalhador para que este venda a sua força de trabalho ao modelo de produção capitalista. No contexto do Estado Social Democrata, mantendo-se a lógica capitalista, a exploração do trabalho, que não deixa de existir, é amenizada, atraindo um aspecto de harmonização de interesses, em razão da concessão de garantias trabalhistas e sociais. Assim, se há uma relação de trabalho, na qual o trabalho alheio é utilizado para o desenvolvimento de um projeto de acumulação de capital, sem o efetivo respeito aos direitos sociais (que servem, muitos deles, à preservação da saúde e para o convívio social e familiar), quebra-se o vínculo básico de uma sociedade sob a égide do Estado de Direito Social. O dado da exploração é o único que sobressai. É a exploração pela exploração, nada mais. A compensação de natureza social não existindo gera, portanto, uma super-exploração. Juridicamente falando, a subordinação se potencializa, fazendo surgir, então, a figura da supersubordinação. $\mathrm{O}$ supersubordinado, por definição, é o 
trabalhador, ser humano, reduzido à condição de força de trabalho, já que desrespeitados, deliberadamente e como estratégia econômica, seus direitos fundamentais. O salário, como todos sabem, destina-se a suprir necessidades vitais básicas do ser humano e as verbas rescisórias ainda mais, sobretudo considerando a condição de desempregado que o trabalhador passa a ostentar. Qualquer pessoa de mediana inteligência e que tenha a capacidade de se colocar no lugar do outro, que também é um cidadão, saberá compreender os problemas pessoais (de natureza patrimonial e extrapatrimonial) sofridos por alguém, que tem na venda da força de trabalho a sua única fonte de sobrevivência e de inserção social, ao não receber em dia o seu salário e quando perde o emprego e, pior ainda, quando isso se dá sem sequer o pagamento das verbas rescisórias.

Inconformados com a r. decisão de fls. 264/269, que julgou parcialmente procedentes os pedidos formulados, recorrem o reclamante a segunda reclamada, pelas razões apresentadas às fls. 276/283 e 285/294, pleiteando a reforma da sentença de primeiro grau.

Contra-razões da segunda reclamada às fls. 302/306.

É o relatório.

V O T O

\section{I - DO RECURSO DO RECLAMANTE}

Presentes os pressupostos recursais, conheço.

a) Da jornada de trabalho

Insurge-se o reclamante pugnando pela descaracterização da jornada implantada pela primeira reclamada no sistema $12 \times 36$, bem como o pagamento das horas que extrapolaram a oitava diária.

Em sua inicial o reclamante alegou que, em média, laborava 80 horas extras mensais.

O D. Magistrado sentenciante entendeu que as normas coletivas acostadas aos autos às fls. 15, 29 e 115 autorizam a escala de 12 horas diárias; que o reclamante não comprovou que a primeira reclamada tenha descumprido as normas coletivas relativamente às horas excedentes ao pactuado "que não abriga a jornada de trabalho postulada pelo autor de $8^{\text {a }}$ diária e $44^{\mathrm{a}}$ semanal”. 
De se considerar, em primeiro lugar, que a jornada no regime 12x36, mormente em horário noturno, como era feito, e com a supressão do intervalo para refeição e descanso, o que foi reconhecido pela própria sentença (fl. 267), é prejudicial à saúde do trabalhador, além de infringir os limites estabelecidos na CLT (arts. 58 e 59).

Ademais, mesmo com a compensação dos dias posteriores, a jornada de 12 horas diárias, sem intervalo, facilita a ocorrência de acidentes, o que vai de encontro à garantia constitucional da redução dos riscos de acidentes de trabalho (art. $7^{\circ}$, XXII, da CF). Confira-se a jurisprudência a respeito:

"JORNADA EM ESCALA 12X36. É ilegal a jornada em escala $12 \times 36$, pois afronta os arts. 58 e 59 da CLT, normas de ordem pública que objetivam a proteção da saúde e segurança do trabalhador, tendo em vista o maior risco de acidentes de trabalho quando se impõe a jornada de 12 horas ao empregado. Portanto, não tem relevância o fato de que a convenção coletiva da categoria ampara o sistema de trabalho na escala supramencionada ( $\operatorname{art.} 7^{\circ}, \mathrm{XXVI}, \mathrm{CF}$ ), militando em favor do obreiro o $\operatorname{art.} 7^{\circ}, \mathrm{XXII}, \mathrm{CF}$, tendo em vista o princípio da proporcionalidade" (TRT $2^{\mathrm{a}}$ Região - $12^{\mathrm{a}}$ T. - Proc. n. 026722005-038-02-00-4 - Rel. Adalberto Martins - DJ 01.02.2008)

Some-se a isso que a primeira reclamada nem mesmo compareceu à audiência, sendo considerada revel.

A segunda reclamada, por sua vez, apenas contestou o pedido de forma genérica, alegando que o reclamante nunca foi seu empregado, e atribuindo validade às normas coletivas que instituíram o regime 12x36 e a compensação de horário.

Portanto, afasta-se a aplicação das normas coletivas e concedese ao reclamante 80 horas extras mensais, conforme alegação inicial, ante a ausência de outras provas e a revelia da primeira reclamada.

b) Honorários advocatícios

A argumentação utilizada pelo D. Juízo de primeiro grau para negar a condenação em honorários advocatícios na Justiça do Trabalho, baseia-se na Lei n. 5.584/70 e nas Súmulas n. 219 e 329 do C. TST.

Todavia, o reclamante não pleiteou honorários advocatícios em razão da sucumbência. Pleiteou, sim, indenização por danos materiais, em razão do prejuízo material causado pelas reclamadas, que o obrigaram a contratar advogado, devendo ser afastada a fundamentação da r. sentença recorrida.

A primeira reclamada é revel. 
A segunda reclamada contestou o pedido por meio dos mesmos argumentos utilizados na r. sentença (fl. 166), que, como dito, não podem ser utilizados para afastar o pleito indenizatório ora formulado.

Portanto, seria o caso mesmo de condenar as reclamadas, na medida de suas responsabilidades, a pagarem ao reclamante a tal indenização, na ordem de $20 \%$ sobre o valor da condenação.

Posta a questão em julgamento, prevaleceu, no entanto, o entendimento dos demais membros da Turma, no sentido de considerar inaplicável a condenação em honorários advocatícios na Justiça do Trabalho, com esteio na Súmula n. 219, do TST.

c) Danos morais.

A r. sentença julgou improcedente o pedido de indenização por danos morais sob o entendimento de que a mora salarial por parte do empregador "pode proporcionar a rescisão indireta do contrato de emprego, mas não é suficiente para ensejar danos morais objetivos ou subjetivos".

Insurge-se o reclamante em face de tal decisão, alegando que a reclamada não pagou as verbas rescisórias e que deixou de receber saldo salarial, tendo sido prejudicado financeiramente, "expondo-se a inadimplência financeira e se sentindo humilhado e moralmente comprometido com tal situação"; que a primeira reclamada sequer compareceu em audiência.

Com razão o recorrente.

$\mathrm{O}$ argumento da sentença é apoiado em uma lógica que não se sustenta. No fundo diz: em face de uma agressão a um direito fundamental (no que se constitui, por certo, o recebimento de salários), o que resta ao empregado é pedir a cessação da relação jurídica por culpa alheia. A agressão em si não tem repercussão específica na ordem jurídica.

Ora, ao ser forçado a deixar o emprego, por não ter recebido salário, e sequer receber as verbas rescisórias, o reclamante foi vítima duas vezes de dano à sua pessoa, pois o desrespeito deliberado e inescusável de direitos trabalhistas conduz o trabalhador a uma condição de sub-cidadania, já que o Direito do Trabalho, conforme expressa o Min. Maurício Godinho, é o marco regulatório mínimo da cidadania (ou o patamar mínimo civilizatório). Não cumprir direitos trabalhistas de forma grosseira, intencional, portanto, não é mero "inadimplemento contratual". Trata-se, isto sim, de uma agressão ao cidadão trabalhador e, porque não dizer, a toda a sociedade.

Lembre-se que o Direito do Trabalho é o retorno de natureza sócio-econômica que se confere ao trabalhador para que este venda a sua força de trabalho 
ao modelo de produção capitalista. A economia mundial só se desenvolveu por intermédio da possibilidade, juridicamente permitida, da exploração do trabalho alheio no contexto de atividades capitalistas. Mas, essa exploração foi acordada (e assim aceita) pela promessa de projeto social. No contexto do Estado Social Democrata, mantendo-se a lógica capitalista, a exploração do trabalho, que não deixa de existir, é amenizada, atraindo um aspecto de harmonização de interesses, em razão da concessão de garantias trabalhistas e sociais.

Assim, se há uma relação de trabalho, pela qual o trabalho alheio é utilizado para o desenvolvimento de um projeto de acumulação de capital, sem o efetivo respeito aos direitos sociais (que servem, muitos deles, para preservação da saúde e para o convívio social e familiar), quebra-se o vínculo básico de uma sociedade sob a égide do Estado de Direito Social. O dado da exploração é o único que sobressai. É a exploração pela exploração, nada mais. A compensação de natureza social não existindo gera uma super-exploração. Juridicamente falando, a subordinação se potencializa, fazendo surgir, então, a figura da supersubordinação.

O supersubordinado, por definição, é o trabalhador, ser humano, reduzido à condição de força de trabalho, já que desrespeitados, deliberadamente e como estratégia econômica, seus direitos fundamentais.

O supersubordinado não é um tipo específico de trabalhador. É a designação do trabalhador, em qualquer relação de emprego, que tenha tido a sua cidadania negada pelo desrespeito deliberado e inescusável aos seus direitos constitucionalmente consagrados $^{105}$.

Houve no presente caso, obviamente, uma superexploração do trabalho, que conduziu o reclamante ao nível da supersubordinação, que requer a devida reparação, como forma de reparação e de desestímulo à prática de atos semelhantes.

Ora, o salário, como todos sabem, destina-se a suprir necessidades vitais básicas do ser humano e as verbas rescisórias ainda mais, sobretudo considerando a condição de desempregado que o trabalhador passa a ostentar.

Qualquer pessoa de mediana inteligência e que tenha a capacidade de se colocar no lugar do outro, que também é um cidadão, saberá compreender os problemas pessoais (de natureza patrimonial e extrapatrimonial) sofridos por alguém, que tem na venda da força de trabalho a sua única fonte de sobrevivência e de inserção social, ao não receber em dia o seu salário e quando perde o emprego e, pior ainda, quando isso se dá sem sequer o pagamento das verbas rescisórias.

Pessoalmente, eu me sentiria muito mal, mas muito mal mesmo,

105. Não se pode conceber que o ordenamento jurídico agasalhe um pretenso "direito a desrespeitar direitos fundamentais". 
se o Tribunal, sem qualquer motivo, deixasse de pagar meus salários, levando-me a uma situação que me obrigasse a pedir exoneração, sem nada receber pela situação causada por ato alheio.

Não há, portanto, como negar procedência à pretensão do reclamante.

Ante ao exposto, reforma-se a r. sentença de primeiro grau para condenar as reclamadas, na medida de suas responsabilidades, conforme definido em sentença, a pagar ao reclamante a indenização requerida no importe de $\mathrm{R} \$ 15.250,00$ (quinze mil, duzentos e cinqüenta reais).

\section{II - DO RECURSO DA SEGUNDA RECLAMADA}

Presentes os pressupostos recursais, conheço.

a) Da ilegitimidade passiva da segunda reclamada

O legitimado para figurar em juízo, como parte passiva é o "titular da obrigação" (art. 6o., do CPC). Apesar de ser uma noção estritamente processual, a verificação da legitimidade se dá, portanto, sob a perspectiva do direito material, porque é neste que se definem os titulares das relações jurídicas (Vicente Greco Filho. Direito processual brasileiro, 1o. Volume. São Paulo, Saraiva, 1989, p. 79).

Em uma terceirização, considerada válida, a doutrina afasta a configuração da relação de emprego com o tomador de serviços. Desse modo, o tomador dos serviços, em análise apressada, não poderia ser considerado parte legítima para figurar em juízo da demanda em que o empregado da empresa prestadora de serviços reclama seus direitos trabalhistas, pois, como visto, no pólo passivo, será parte legítima o titular da obrigação, entendendo-se obrigação, como "o vínculo jurídico em virtude do qual uma pessoa pode exigir de outra uma prestação economicamente apreciável" (cf. Caio Mário da Silva Pereira. Istituições de Direito Civil, Vol. II. Rio de Janeiro, Forense, 1978, p. 12).

As obrigações decorrem ou da vontade ou da lei, isto é, independentemente, de expressa manifestação de vontade (Caio Mário, p. 40). Entretanto, relata Caio Mário da Silva Pereira (Caio Mário, p. 28), os autores civilistas modernos acentuam a dualidade das obrigações: o débito e a responsabilidade.

O débito é o dever de realizar certa atividade que o sujeito passivo da relação obrigacional tem perante o credor. Não a cumprindo, surge para o sujeito ativo a possibilidade de, mobilizando as forças do Estado, exigir o cumprimento da obrigação. Trata-se da responsabilidade que é gerada pelo débito, e que permite imporemse sanções ao devedor, sob o aspecto patrimonial.

Assim, a responsabilidade surge quando ocorre o inadimplemento da obrigação. 
A responsabilidade, embora seja um dos fatores da obrigação, caminhando lado a lado com o débito, pode surgir autonomamente, como nos casos de alguém que garante uma dívida de outra pessoa (fiança, por exemplo).

A sentença não cria a relação obrigacional. Esta lhe é sempre antecedente, conforme acentua Caio Mário (p. 41), mas a sentença pode declarar uma responsabilidade de caráter autônomo, com relação a certa obrigação, já que a responsabilidade não decorre necessariamente do vínculo obrigacional.

A responsabilidade pode decorrer de ato culposo, sendo, até, indiferente a vontade do agente de causar o dano, ou mesmo a consciência da violação. A culpa, que dá origem à responsabilidade, tanto pode ser contratual quanto extracontratual, também chamada aquiliana. A culpa aquiliana "é a transgressão do dever legal positivo de respeitar o bem jurídico alheio, ou o dever geral de não causar dano a outrem, quando a conduta do agente não está regulada por uma convenção" (Caio Mário, pp. 286-287).

A exigência social, que requer uma resposta do direito, expressa-se no sentido de que todo dano seja reparado pelo transgressor. Para ampliar as possibilidades jurídicas de satisfazer essa exigência social, criou-se a teoria da culpa in eligendo, estabelecendo-se uma responsabilidade "quando há má escolha da pessoa a quem uma tarefa é confiada" (Caio Mário, p. 288).

Dessas lições extrai-se que a busca da responsabilidade pela via judicial é plenamente válida e aquele a quem se quer imputar a responsabilidade deve ser, necessariamente, parte passiva na demanda.

Assim, rejeita-se a preliminar de ilegitimidade argüida pela recorrente.

b) Horas em prorrogação ao horário noturno

Pretende a recorrente a reforma da r. sentença, alegando que não se poderia determinar o pagamento de diferenças de horas extras considerando o labor após as 5 (cinco) horas como hora noturna reduzida; que houve violação ao art. 73, da CLT.

Sem razão a recorrente.

A Súmula n. 60 do C. TST é bastante clara:

"Adicional noturno. Integração no salário e prorrogação em horário diurno. (RA 105/1974, DJ 24.10.1974. Nova redaç ̨o em decorrência da incorporaç a da Orientaç مo Jurisprudencial n6 da SDI-1 - Res. 129/2005, DJ 20.04.2005)

I - O adicional noturno, pago com habitualidade, integra $\mathrm{o}$ salário do empregado para todos os efeitos.

II - Cumprida integralmente a jornada no período noturno e 
prorrogada esta, devido é também o adicional quanto às horas prorrogadas. Exegese do art. $73, \S 5^{\circ}$, da CLT"

Nada a reparar na r. sentença.

c) Intervalo intrajornada

Insurge-se a recorrente pretendendo a reforma da r. sentença sob o entendimento de que a Convenção Coletiva juntada aos autos autorizou a concessão de intervalo de apenas 30 minutos; que não é devido o pagamento integral, mas apenas da diferença não concedida; e que não é devido o pagamento como se hora extra fosse.

Sem razão a recorrente.

O intervalo para refeição e descanso é preceito de ordem pública que visa a preservar a integridade física do empregado. A sua inobservância, portanto, representa um dano à pessoa do empregado, sendo incontestável que qualquer norma que autorize a sua redução vai de encontro à própria Constituição Federal (art. $7^{\circ}$, XXII, $\mathrm{CF} / 88)$.

Nesse sentido, dispõe a O.J. n. 342 da SDI do C. TST: "é inválida cláusula de acordo ou convenção coletiva de trabalho contemplando a supressão ou redução do intervalo intrajornada porque este constitui medida de higiene, saúde e segurança do trabalho, garantido por norma de ordem pública (art. 71 da CLT e art. $7^{\circ}$, XXII, da CF/88), infenso à negociação coletiva".

Ademais, considerando-se que a concessão do intervalo para refeição e descanso em período menor que 1 (uma) hora não é menos prejudicial à saúde do trabalhador que a não concessão deste, tem-se, pela interpretação razoável do art. 71, $\S 4^{\circ}$, da CLT, que a redução do intervalo é o mesmo que a sua supressão, sendo devido, em qualquer hipótese, o pagamento de uma hora normal de trabalho acrescida do adicional de, no mínimo, $50 \%$.

O C. TST já pacificou seu entendimento por meio da O.J. n. 307 da SDI-1: “307 - Intervalo intrajornada (para repouso e alimentaç ૨o). Não concessão ou concess po parcial. Lei n8.923/94 ؛ (DJ 11.08.2003) Após a edição da Lei no 8.923/1994, a não-concessão total ou parcial do intervalo intrajornada mínimo, para repouso e alimentação, implica o pagamento total do período correspondente, com acréscimo de, no mínimo, 50\% sobre o valor da remuneração da hora normal de trabalho (art. 71 da CLT).”

Por fim, devidos os valores respectivos como se horas extras fossem, não podendo ser acolhida a tese de que o pagamento feito, com base no parágrafo $4^{\mathrm{O}}$, do art. 71, da CLT, não possui natureza salarial e sim indenizatória. Primeiro porque tal conclusão fere a regra geral da configuração da natureza das parcelas pagas ao trabalhador, fixada no art. 457, da CLT, da qual se extrai que todo beneficio concedido ao empregado, 
de forma habitual, integra a sua remuneração. Segundo porque só se pode chegar à conclusão de que uma parcela habitual devida ao empregado não é salário se houver lei prevendo a exceção, como ocorre, por exemplo, com o vale-transporte, a alimentação, nos moldes do PAT e a participação nos lucros. Por critério hermenêutico, não se pode chegar às exceções por interpretação ampliativa. As exceções se interpretam, restritivamente. Terceiro porque o próprio texto da lei, $\S 4^{\mathrm{o}}$, do art. 71, da CLT, é expresso no sentido de que o adicional incide sobre a remuneração do empregado. E quarto, porque se tal argumento fosse verdadeiro para o intervalo, também seria para o adicional de insalubridade, o adicional de periculosidade, o adicional noturno e até mesmo para o adicional de horas extras. Sabe-se bem que com relação a estas outras parcelas não se discute a sua natureza salarial e estando a supressão do intervalo dentro da mesma lógica não se lhe pode dar solução diferente. A construção do direito, da qual participa, definitivamente, a jurisprudência, pressupõe a preservação da lógica e da coerência do sistema.

Nada a reparar na r. sentença.

d) Demais verbas deferidas

Sustenta a recorrente, sem razão, que não poderia ser responsabilizada pela multa do art. 477 , da CLT, e pela indenização do desconto no importe de $\mathrm{R} \$ 517,25$, em face de acidente ocorrido nas dependências da segunda reclamada.

Ante a responsabilização subsidiária da segunda reclamada, em relação a todas as verbas trabalhistas, de natureza punitiva, ou não, mantém-se a $r$. sentença. O item IV da Súmula n. 331, do C. TST, aplicada pelo D. Juízo sentenciante é claro no sentido de que "o inadimplemento das obrigações trabalhistas, por parte do empregador, implica a responsabilidade subsidiária do tomador dos serviços, quanto àquelas obrigações ...”.

Indiferente o fato de a recorrente não ter dado causa ao atraso no pagamento das verbas rescisórias, já que sua responsabilidade, fixada nos moldes da Súmula n. 331, do C. TST, decorre unicamente do fato de a primeira reclamada ser devedora.

Mantém-se a r. sentença.

e) Seguro-desemprego

Quanto ao seguro desemprego, não assiste razão à recorrente ao alegar que "a obrigação empresarial cinge-se à entrega das guias, não havendo hipótese normativa autorizando o pagamento de indenização substitutiva".

A indenização substitutiva decorre do dever de reparação do 
prejuízo causado (arts. 186 e 927, do CC), nada havendo a reparar na r. sentença.

\section{O N C L U S Ã O}

Pelo exposto, resolvo conhecer dos recursos apresentados e, no mérito, negar provimento ao recurso da segunda reclamada e dar parcial provimento ao do reclamante, reformando a $\mathrm{r}$. sentença de primeiro grau para condenar as reclamadas ao pagamento de horas extras e indenização por danos morais no importe de $\mathrm{R} \$ 15.270,00$, tudo nos termos da fundamentação supra e nos limites do pedido.

JORGE LUIZ SOUTO MAIOR

Juiz Relator 